
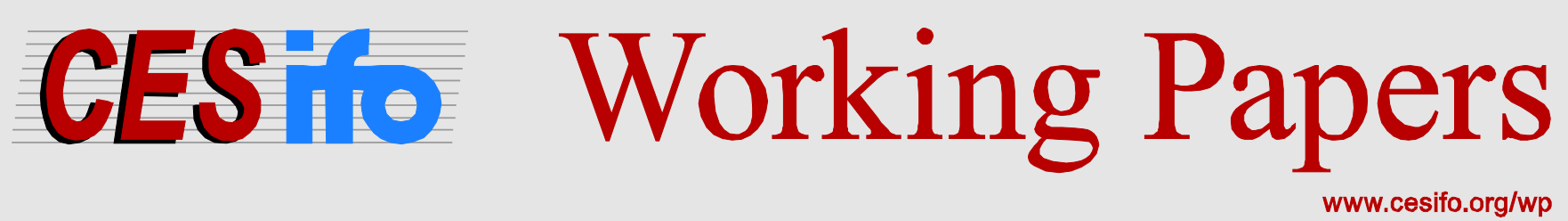

\title{
Going Deep: The Trade and Welfare Effects of TTIP
}

\author{
Rahel Aichele \\ Gabriel Felbermayr \\ Inga Heiland
}

CESIFO WORKING PAPER NO. 5150

CATEgory 8: Trade Policy

DECEMBER 2014

An electronic version of the paper may be downloaded
- from the SSRN website:
• from the RePEc website:
- from the CESifo website: 


\title{
Going Deep: The Trade and Welfare Effects of TTIP
}

\begin{abstract}
Since July 2013, the EU and the US have been negotiating a preferential trade agreement (PTA), the Transatlantic Trade and Investment Partnership (TTIP). We use a multi-country, multi-industry Ricardian trade model with national and international input-output linkages to quantify its potential economic consequences. We structurally estimate the sectoral trade flow elasticities of trade costs and of existing PTAs. We simulate the trade, value added, and welfare effects of the TTIP, assuming that the agreement would eliminate all transatlantic tariffs and reduce non-tariff barriers as other deep PTAs have. The long-run level of real per capita income would change by $2.12 \%$ in the EU, by $2.68 \%$ in the US, and by $-0.03 \%$ in the rest of the world relative to the status quo. However, there is substantial heterogeneity across the 134 geographical entities that we investigate. Gross value of EU-US trade could triple, but its value added would grow by substantially less. Moreover, trade diversion effects are more pronounced in value added trade than in gross trade. This signals a deepening of the transatlantic value chain.
\end{abstract}

JEL-Code: F130, F140, F170.

Keywords: structural gravity, preferential trade agreements, TTIP.

Rahel Aichele
Ifo Institute - Leibniz Institute for
Economic Research
at the University of Munich
Poschingerstrasse 5
Germany - 81679 Munich
aichele@ifo.de

We thank Lorenzo Caliendo, Peter Egger, Marc-Andreas Muendler, Mario Larch, and seminar participants in Lisbon, Munich, Rome, Venice, and Vienna for comments and suggestions. This paper provides the technical details for a report that the authors have prepared for the Bertelsmann foundation. 


\section{Motivation}

In July 2013, the EU and the US have begun negotiations on a Transatlantic Trade and Investment Partnership (TTIP). According to the High-Level Working Group (HLWG) on Jobs and Growth, set up by the so called Transatlantic Economic Council (TEC), the ambition is to eliminate all tariffs and to create "... a comprehensive, ambitious agreement that addresses a broad range of bilateral trade and investment issues, including regulatory issues, and contributes to the development of global rules" that "goes beyond what the United States and the EU have achieved in previous trade agreements." In this paper, we attempt a quantification of the potential effects of this endeavor.

TTIP is the first big trade agreement that tries to fill the "gap between 21st century trade and the 20th century trade rules" (Baldwin, 2011) that the relative stasis of the World Trade Organization (WTO) has left developed countries in. Our analysis captures the reality of international production networks and trade in intermediate inputs. It focuses on non-tariff barriers besides tariffs, and it explores scenarios in which the systemic importance of the TTIP also leads to trade cost reductions elsewhere, either through what Francois et al. (2013) have called spillovers, or through the completion of the Doha Round.

And it does so by extending the recent quantitative trade models by Eaton and Kortum (2002) and Caliendo and Parro (2014) to PTAs. Our framework covers 32 industries from the services, manufacturing and agriculture sectors for 134 countries or regions. It incorporates tariffs as well as non-tariff measures (NTMs). By allowing intra- and international trade of intermediate inputs into this stochastic Ricardian model, it allows to model international production networks and allows to differentiate the value added content from the gross value of bilateral trade flows. In contrast to the conventional CGE trade models, the key parameters - the Frechet parameter governing the distribution of productivities within sectors, or the coefficients of the trade cost function - are estimated using structural relationships strictly implied by the theoretical setup. 
Using data on sectoral trade flows and input-output linkages from the Global Trade Analysis Project (GTAP) and applying instrumental variables (IV) techniques to obtain unbiased parameter estimates, the central assumption of the analysis is that the TTIP between the EU and the USA will reduce trade costs by as much as other already existing deep trade agreements have. The key results are that the TTIP will yield a long-run increase in the level of real per capita income of $2.12 \%$ and $2.68 \%$ in the EU and the US, respectively. It would only marginally lower average real income in the rest of the world, leaving the world as a whole better off by about $1.32 \%$. If it were combined with the full elimination of tariffs within the group of WTO countries, almost all countries in the world would win. Similarly, if trade cost reductions between the EU and the US also improve the access of third countries to the TTIP partners or to each other, all could be made better off.

We find that the TTIP would result in a significant amount of trade creation between the insiders. For example, trade between Germany and the US, as measured at the customs, could go up by more than $200 \%$. At the same time, trade with the other EU countries would fall by between 5 and 10\%, reflecting trade diversion by preference erosion. Similarly, trade with most third countries or regions would go down. However, imports from suppliers of raw materials or intermediates can go up, reflecting the effect of higher income and of increased industrial production in TTIP partners. Also, trade diversion can be attenuated by imported competitiveness: when TTIP partners supply intermediates at lower prices to third countries, changes in relative prices of final goods are dampened. This latter effect, plus the restructuring of production chains explains the interesting finding that the value added content of trade flows goes up, sometimes substantially, in many trade relationships.

The introduction of a TTIP would alter the composition of aggregate value added. It would lead to a slight reindustrialization in the TTIP partners, reflecting the fact that the reduction in trade barriers is larger in manufacturing than in services. Moreover, the 
model does not predict that the sectoral impact simply follows the structure of comparative advantage as measured by the Balassa-Samuelson index. Again, this follows from the fact that changes in the competitiveness of sectors is very much driven by changes in the prices of intermediate goods, both domestic and imported.

The paper is related to three important strands of literature. First, it builds on recent work on quantitative trade models. Costinot and Rodríguez-Clare (2014) provide an excellent survey. The central element in these models is the gravity equation, a parsimonious relationship which allows to estimate parameters with the help of relatively simple econometrics but which requires strong functional assumptions. In our case, the Frechet distribution and CES demand systems. The great advantage of the gravity equation is its excellent empirical fit. However, this does not imply that out-of-sample its fit will be perfect as well. Nonetheless, the new "quantitative trade theory" offers important advantages over the more conventional large-scale CGE approach. First, the parsimony allows going relatively far with analytical descriptions. This feature reduces (but does not undo) the black box nature of large general equilibrium models. Second, the approach allows a tight link between theoretical structure and parameter estimation which allows a neater calibration. Finally, by exploiting what we know from existing deep agreements, one does not require bottom-up estimates of NTMs and one can let the data define the TTIP scenario.

Second, our work builds on earlier quantitative evaluations of the TTIP. In a study for the European Commission, Francois et al. (2013) employ a large scale CGE framework based on the well-known GTAP model (Hertel, ed, 1997) and extended to include features from the Francois et al. (2005) model. While their work is at the frontier of classical CGE modeling, it does not utilize the breakthroughs described in Costinot and Rodríguez-Clare (2014). It requires bottom-up estimates of NTMs which are, however, only available for a small set of bilateral trade links, and it defines the scenario on the basis of expert input rather than data. Egger et al. (2014) use the same model, but they rely on a top-down, 
gravity-based approach to NTMs. However, they do not derive the gravity equation from the model and they seem to use ad hoc calibration to parameterize other model parameters (such as trade elasticities). Moreover, these studies work with regional aggregates.

Felbermayr et al. (2013) and Felbermayr et al. (2014) apply the model and econometric approach of Egger et al. (2011) to simulate the effects of a possible TTIP. The model is a single-sector framework based on the Krugman (1980) model augmented with an extensive margin to capture the prevalence of zero-trade flows. The approach features a tight link between gravity estimation and model structure. However, it does not feature sectoral detail nor does it allow addressing production networks. The work by Anderson et al. (2014) sticks to the single-sector setup but endogenizes the capital stock in a fully structural quantitative trade model. These models have the advantage of great tractability and they can be understood as reduced-form approaches to more complicated setups.

Finally, the present paper relates to a large empirical literature on the determinants and effects of PTAs. Much of the earlier work, as surveyed by Cipollina and Salvatici (2010), is based on reduced form equations and does not properly deal with the potential endogeneity of trade agreements. More recent empirical studies provide a tight link between theoretical model and estimation (see Head and Mayer, 2014), and devote much attention to obtain the causal effects of PTAs on trade flows (see Egger et al., 2011, and the discussion of literature therein). The critical step is to find exogenous drivers of PTA formation. Controlling for tariffs, the estimated treatment effect of PTAs can be used to quantify how PTAs have reduced the costs of non-tariff barriers to trade. Interestingly, the literature suggests that OLS estimates tend to underestimate the true effects of PTAs and that their effect on NTMs must be quite substantial. In our work we provide instrumental variables estimates for 32 sectors (including services) and we distinguish between two types of PTA depth, borrowing a classification provided by Dür et al. (2014).

The remainder of this paper is structured as follows. Section 2 provides a quick overview of the theoretical model. Section 3 discusses the data and the identification of 
parameters. Section 4 provides the results of the simulation of counterfactual scenarios pertaining to the TTIP. Finally, Section 5 summarizes and concludes.

\section{Methodology}

We briefly summarize the Eaton and Kortum (2002)-type multi-sector, input-output gravity model developed by Caliendo and Parro (2014) used in our simulations. Their counterfactual analysis deals with the elimination of tariffs between the NAFTA countries. The TTIP will reduce NTMs along with tariffs. It will also provide a deep trade liberalization and go beyond the trade liberalizing effect of many existing PTAs. So to better capture these tariff and NTM trade cost reductions, we introduce PTAs of different depth into the Caliendo and Parro (2014) framework. We characterize the equilibrium changes after a trade policy shock to pave the path for our counterfactual analysis.

Compared to one sector models or models without input-output linkages, the model chosen here features additional welfare channels - an intermediates goods and sector linkages channel (see the discussion in Caliendo and Parro, 2014). Global value chains are increasingly important. The model helps to capture the additional effects.

\subsection{The Gravity Model}

In $n=1, \ldots, N$ countries, the utility function of the representative household is described by a Cobb-Douglas function over $j=1, \ldots, J$ sectoral composite goods. $\alpha_{n}^{j}$ denotes a sector's expenditure share. The household receives labor income $I_{n}$ and lump-sum tariff rebates.

Each sector $j$ comprises a continuum of varieties. Labor and the composite goods of each sector $k=1, \ldots, J$ are the inputs in $j$ 's production process. Let $\beta_{n}^{j} \in[0,1]$ denote

the cost share of labor and $\gamma_{n}^{k, j} \in[0,1]$ the share of sector $k$ in sector $j$ 's intermediate 
costs, with $\sum_{k=1}^{J} \gamma_{n}^{k, j}=1$. Then the production function for a variety $\omega^{j}$ is given by

$$
q_{n}^{j}\left(\omega^{j}\right)=x_{n}^{j}\left(\omega^{j}\right)^{-\theta^{j}}\left[l_{n}^{j}\left(\omega^{j}\right)\right]^{\beta_{n}^{j}}\left[\prod_{k=1}^{J} m_{n}^{k, j}\left(\omega^{j}\right)^{\gamma_{n}^{k, j}}\right]^{\left(1-\beta_{n}^{j}\right)}
$$

where $x_{n}^{j}\left(\omega^{j}\right)$ denotes the inverse efficiency of variety producer $\omega^{j}$. The dispersion of efficiencies across varieties is given by $\theta^{j} \in(0,1)$. The higher $\theta^{j}$, the greater the productivity dispersion in sector $j$. All varieties $\omega^{j}$ are aggregated with a Dixit-Stiglitz CES technology into sector $j$ 's composite good. It can be used for production or consumption purposes.

A sector's varieties are internationally traded. Producers search across all countries for the lowest-cost supplier of a variety. When importing good $j$ from country $i$ to country $n$, the importer has to pay the unit $\operatorname{costs} c_{i}^{j}$ times the trade $\operatorname{costs} \kappa_{i n}^{j}$ which consist of two parts: ad-valorem tariffs $\tau_{i n}^{j} \geq 0$ and iceberg trade costs $d_{i n}^{j} \geq 1$, with $d_{n n}^{j}=1$. Following other gravity applications, we can model iceberg trade costs as a function of bilateral distance, PTAs and other observable trade cost proxies such as sharing a common border, a common language or a common colonial history. So $d_{i n}^{j}=D_{i n}{ }^{\rho^{j}} e^{\delta^{j} \mathbf{z}_{i n}}$, where $D_{i n}$ is bilateral distance, and $\mathbf{Z}_{i n}$ is a vector collecting dichotomous trade cost proxies. More explicitly, we allow for two types of PTAs: shallow and deep treaties. The respective dummies are denoted by $P T A_{\text {shallow }}$ and $P T A_{\text {deep }}$. Since tariffs are an explicit part of trade costs, the PTA dummies capture trade cost reductions that go beyond the reduction or elimination of tariffs. Thus, the PTA dummies capture the trade-enhancing effect of reducing non-tariff trade barriers like sanitary and phytosanitary trade barriers and other technical barriers to trade like regulatory standards or labeling requirements.

The model gives rise to a gravity equation. Country $n$ 's expenditure share $\pi_{i n}^{j}$ for source country $i$ 's goods in sector $j$ depends on $i$ 's price relative to the price index. It can be written as

$$
\pi_{i n}^{j}=\frac{\lambda_{i}^{j}\left[c_{i}^{j} \kappa_{i n}^{j}\right]^{\frac{-1}{\theta^{j}}}}{\sum_{i=1}^{N} \lambda_{i}^{j}\left[c_{i}^{j} \kappa_{i n}^{j}\right]^{\frac{-1}{\theta^{j}}}} .
$$


This trade share can be interpreted as the probability that, for country $n$, the lowest cost supplier of a variety in sector $j$ is trade partner $i$. The model is closed with goods market clearing and an income-equals-expenditure condition for each country $n$.

Due to intermediates goods trade, there is double-counting of value added in trade statistics. Koopman et al. (2014) show how to decompose countries' trade flows into various value added and double-counted parts. ${ }^{5}$ Aichele and Heiland (2014) propose to study production networks by looking at the value added flows that are processed into final goods by one region and then absorbed in another one. Following Johnson and Noguera (2012), they derive counterfactual value added trade flows after a trade policy shock in the Caliendo and Parro (2014) model setup. We apply the same methodology and contrast the effects of the TTIP on trade flows, value added trade flows and production networks.

\subsection{Comparative Statics in General Equilibrium}

We are interested in the trade and welfare effects of the TTIP. In this section, we describe how the model reacts to a trade policy shock. Let $\hat{x} \equiv x^{\prime} / x$ be the relative change in a variable from its initial level $x$ to the counterfactual level $x^{\prime}$. The formation of a PTA implies changes in the tariff schedule and the reduction of NTMs. So the trade cost changes are given by $\hat{\kappa}_{i n}^{j}=\hat{\tau}_{i n}^{j} e^{\delta_{\text {shallow }}^{j}\left(P T A_{\text {shallow }, i n}^{\prime}-P T A_{\text {shallow }, i n}\right)+\delta_{\text {deep }}^{j}\left(P T A_{\text {deep }, i n}^{\prime}-P T A_{\text {deep }, i n}\right)}$. Since all trade flows between liberalizing countries benefit from the tariff and NTM cost reductions, the approach implicitly assumes that either rules of origin do not matter or the local content is sufficiently high.

As suggested by Dekle et al. (2008) one can solve for equilibrium changes: ${ }^{6}$

\footnotetext{
${ }^{5}$ Following Koopman et al. (2014), Wang et al. (2013) develop a methodology to decompose trade flows at the bilateral and sectoral level.

${ }^{6}$ When solving for the new equilibrium in changes instead of in levels, the set of parameters that have to be estimated is reduced. Information on price levels, iceberg trade costs, or productivity levels are not required.
} 


$$
\begin{aligned}
\hat{c}_{n}^{j} & =\hat{w}_{n}^{\beta_{n}^{j}}\left(\prod_{k=1}^{J}\left[\hat{p}_{n}^{k}\right]_{n}^{\gamma_{n}^{k, j}}\right)^{1-\beta_{n}^{j}}, \\
\hat{p}_{n}^{j} & =\left(\sum_{i=1}^{N} \pi_{i n}^{j}\left[\hat{\kappa}_{i n}^{j} \hat{c}_{i}^{j}\right]^{-1 / \theta^{j}}\right)^{-\theta^{j}}, \\
\hat{\pi}_{i n}^{j} & =\left(\frac{\hat{c}_{i}^{j}}{\hat{p}_{n}^{j}} \hat{\kappa}_{i n}^{j}\right)^{-1 / \theta^{j}}, \\
X_{n}^{j^{\prime}} & =\sum_{k=1}^{J} \gamma_{n}^{j, k}\left(1-\beta_{n}^{k}\right)\left(\sum_{i=1}^{N} \frac{\pi_{n i}^{k^{\prime}}}{1+\tau_{n i}^{k^{\prime}}} X_{i}^{k^{\prime}}\right)+\alpha_{n}^{j} I_{n}^{\prime}, \\
\sum_{j=1}^{J} F_{n}^{j^{\prime}} X_{n}^{j^{\prime}}+S_{n} & =\sum_{j=1}^{J} \sum_{i=1}^{N} \frac{\pi_{n i}^{j^{\prime}}}{1+\tau_{n i}^{j^{\prime}}} X_{i}^{j^{\prime}},
\end{aligned}
$$

where $\hat{w}_{n}$ denotes the wage change, $X_{n}^{j}$ denotes the sectoral expenditure level, $F_{n}^{j} \equiv$ $\sum_{i=1}^{N} \frac{\pi_{i n}^{j}}{\left(1+\tau_{i n}^{j}\right)}, I_{n}^{\prime}=\hat{w}_{n} w_{n} L_{n}+\sum_{j=1}^{J} X_{n}^{j^{\prime}}\left(1-F_{n}^{j^{\prime}}\right)-S_{n}, L_{n}$ is country $n$ 's labor force ${ }^{7}$, and $S_{n}$ is the trade surplus. Equation (3) shows how unit costs react to input price changes, i.e. to wage and intermediate price changes. Trade cost changes affect the sectoral price index $p_{n}^{j}$ directly, and also indirectly by affecting unit costs (see Equation (4)). Changes in trade shares result from these trade cost, unit cost and price changes. The strength of the reaction is governed by the productivity dispersion $\theta^{j}$. A high $\theta^{j}$ implies bigger trade changes. Equation (6) ensures goods market clearing in the new equilibrium and Equation (7) corresponds to the counterfactual income-equals-expenditure or balanced trade condition. The change in real income which is given by

$$
\widehat{W}_{n}=\frac{\hat{I}_{n}}{\prod_{j=1}^{J}\left(\hat{p}_{n}^{j}\right)^{\alpha_{n}^{j}}}
$$

serves as a statistic to assess welfare changes.

Caliendo and Parro (2014) extend the single-sector solution algorithm proposed by

\footnotetext{
${ }^{7}$ Labor can move freely between sectors. However, it cannot cross international borders.
} 
Alvarez and Lucas (2007) to solve the system of equations given by (3)-(7). The algorithm starts with an initial guess about a vector of wage changes. With (3) and (4), it then computes price and trade share changes and the new expenditure levels based on those wage changes, evaluates the trade balance condition (7), and then updates the wage change based on the error in the trade balance.

\section{Data and Parameter Identification}

To simulate the effects of TTIP in general equilibrium, we need to identify the model parameters $\alpha, \beta, \gamma, \theta$, and $\delta_{\text {shallow }}$ and $\delta_{\text {deep }}$, and collect data on bilateral trade shares $\pi$, tariff levels $\tau$, countries' total value added $w_{n} L_{n}$, and trade surpluses $S_{n}$. The expenditure shares $\alpha$ and the cost shares $\beta$ and $\gamma$ are obtained from input-output tables. $\theta, \delta_{\text {shallow }}$ and $\delta_{\text {deep }}$ are estimated based on the gravity equation following from the model.

\subsection{Data Sources}

Our main data source is the Global Trade Analysis Project (GTAP) 8.1 database, which provides sectoral production values, sectoral value added information and bilateral final and intermediate goods trade in producer and consumer prices, including for service sectors. Given this information, we can construct bilateral tariffs, bilateral input-output tables and expenditure levels. The GTAP database was chosen for its rich country detail. ${ }^{8}$ It contains data for 114 countries and 20 aggregate regions (e.g. "Rest of Southeast Asia"). These 134 countries and regions represent the world economy in the year 2007. GTAP distinguishes 58 sectors. We further aggregate the sectors into 32 industries to keep the simulations tractable. The aggregation pertains mostly to agricultural, resource and

\footnotetext{
${ }^{8}$ The World Input Output Database (WIOD) constitutes an alternative data source. It provides the same information for a sample of 40 countries and the rest of the world for the years 1995-2011. Since we are interested in trade creation and trade diversion and third country effects, we want to have as much country detail as possible.
} 
Figure 1: Status quo of depth of trade integration

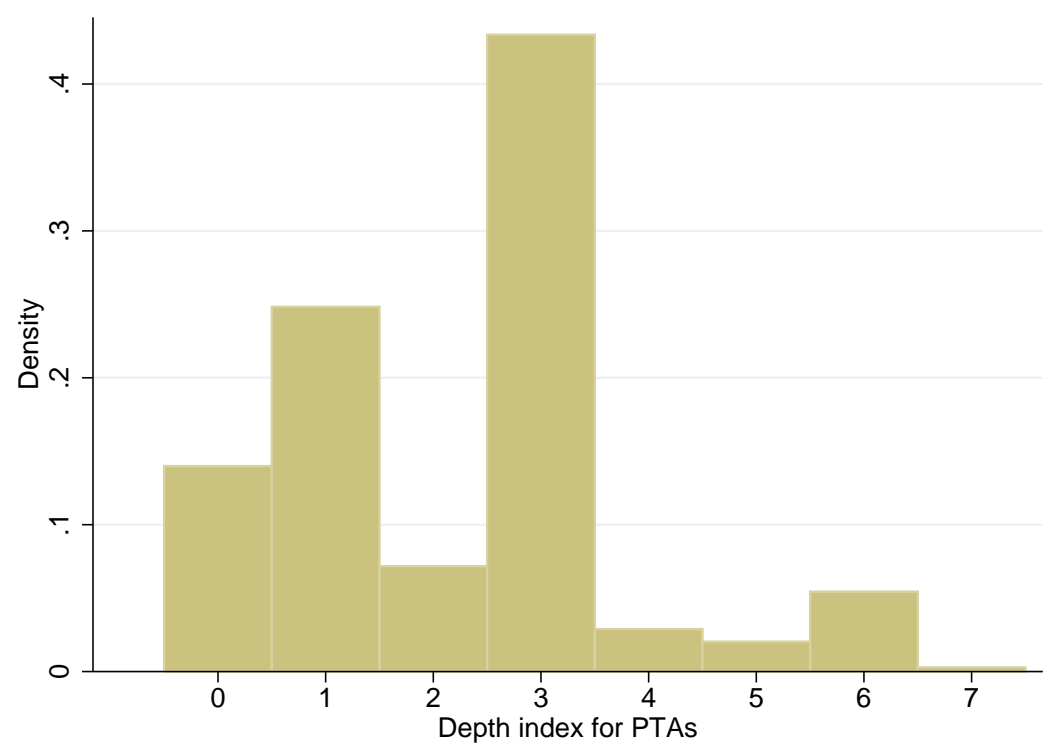

Note: The figure plots the index of depth of PTAs as classified by Dür et al. (2014) for country pairs with a PTA in 2007. The depth index counts the number of provisions and ranges from 0-7. The different provisions are: partial scope agreement, substantive provisions on services, investments, standards, public procurement, competition and intellectual property rights.

processed food sectors but we keep the sectoral detail in the manufacturing and services industries..$^{9}$

A key element of our simulations is to distinguish shallow from deep PTAs. The depth of existing PTAs is constructed from the Design of Trade Agreements (DESTA) database (see Dür et al., 2014). The database offers an index of depth which counts the numbers of provisions (partial scope agreement, substantive provisions on services, investments, standards, public procurement, competition and intellectual property rights) the respective PTA covers. The index ranges from 0 to 7 , where 0 indicates a partial scope agreement and 7 is the deepest level of integration. We recode this index of depth to obtain two classes of PTAs: shallow and deep agreements. The dummy indicating a shallow PTA switches to one if the depth index lies between 0 and 7 . The dummy for

\footnotetext{
${ }^{9}$ An overview of the sectoral breakdown is provided in Table A1 in the online appendix.
} 
a deep PTA takes the value of one if it index is between 4 and $7 .{ }^{10}$ Figure 1 shows the distribution of the depth of existing PTAs for the year 2007. About $10 \%$ of the PTAs (i.e., 836 bilateral relations out of the 7997 with a PTA) are classified as deep according to our definition; examples include NAFTA, the EU or USA-Korea. The Andean Community, MERCOSUR or ASEAN are examples for shallow agreements.

\subsection{Identification of Trade Cost Parameters}

The trade cost parameters $\theta$ and $\delta$ can be identified from the gravity equation. Take the trade share equation (2), plug in the functional form for trade costs and multiply by the total expenditure $X_{n}^{j}$, to obtain the following log-linearized estimable gravity equation for each sector $j$ :

$$
\ln \left(\pi_{i n}^{j} X_{n}^{j}\right)=-\frac{1}{\theta^{j}} \ln \tau_{i n}^{j}-\frac{\rho^{j}}{\theta^{j}} \ln D_{i n}-\frac{\boldsymbol{\delta}_{\boldsymbol{d}}^{j}}{\theta^{j}} \mathbf{P T A}_{d, i n}-\frac{\zeta^{j}}{\theta^{j}} \mathbf{Z}_{i n}+\nu_{i}^{j}+\mu_{n}^{j}+\varepsilon_{i n}^{j}
$$

where $\boldsymbol{\delta}_{\boldsymbol{d}}^{j}=\{$ shallow, deep $\}, \nu_{i}^{j} \equiv \ln \left(\lambda_{i}^{j} c_{i}^{j}\right)$ and $\mu_{n}^{j} \equiv \ln \left(X_{n}^{j} / \sum_{i=1}^{N} \lambda_{i}^{j}\left[c_{i}^{j} \kappa_{\text {in }}^{j}\right]^{\frac{-1}{\theta^{j}}}\right)$ are importer and exporter fixed effects, respectively, and $\varepsilon_{i n}^{j}$ is an i.i.d. error term.

The coefficient on tariffs directly identifies the productivity dispersion, $1 / \theta^{j}$. The higher $1 / \theta^{j}$, the stronger the response of trade flows to a cost shifter (here bilateral tariffs). The coefficients on PTAs, $-\frac{\delta_{d^{j}}}{\theta^{j}}$, are expected to be positive. Forming a PTA reduces nontariff trade barriers, and thus, bilateral trade increases. The coefficient is allowed to vary

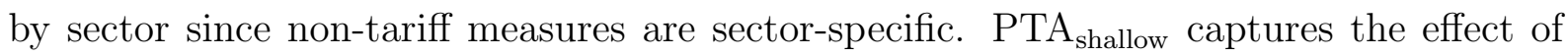
having a PTA. PTA deep captures the additional effects of having a deep agreement. If $-\frac{\delta_{\mathrm{deep}^{j}}}{\theta^{j}}$ is not statistically different from zero, in our data, deep trade liberalization does not provide stronger trade cost reductions than a shallow PTA. In our counterfactual analysis, we assume that the TTIP will reduce the costs of non-tariff measures by the

\footnotetext{
${ }^{10}$ In the regressions, the average effect of a PTA is given by the coefficient on the shallow PTA; the effect of the deep PTA is added to this average.
} 
same amount that other PTAs have reduced trade barriers. Thus, we do no not need direct estimates of the levels of NTMs for the 18,000 trade pairs in our analysis, ${ }^{11}$ nor do we need to speculate about changes in the costs of NTMs that may result from signing the TTIP.

The importer and exporter fixed effects take into account that bilateral trade volumes are influenced by country characteristics. However, the estimates of the PTA dummies could still suffer from an endogeneity bias when, e.g., countries that trade more with each other are also more likely to sign a PTA. In this case, the PTA dummy would overestimate the trade enhancing effect of a PTA. To reduce the endogeneity bias, we use an instrumental variables approach. The instruments should influence the probability to sign a PTA, but other than through the PTA should not affect current trade levels. One such instrument is the contagion index developed by Baldwin and Jaimovich (2012) and, e.g., also used in Martin et al. (2012). It measures the threat of trade diversion country $i$ faces in a trade partner $j$ 's market, by counting $j$ 's PTAs with third countries weighted with how important the third country's market is for $i$ (i.e. with the third country's share in $i$ 's exports). Additionally, we use historical and recent war frequency and lagged average variables for political similarity (average of 2000-2005) as instruments (see Egger et al., 2008, for a brief discussion). The rationale for these variables is that past conflicts will make it harder to negotiate PTAs, while political similarity might make it easier.

Table 1 displays the IV gravity results for the productivity dispersion and the PTA effects for the 17 manufacturing sectors. ${ }^{12}$ We drop the $0.5 \%$ of outlier observations with the highest tariffs from the sample. In general, our estimations can explain between 60

\footnotetext{
${ }^{11}$ We model $134 \times 133=17,822$ country pairs.

${ }^{12}$ The estimation is based on trade data from UN COMTRADE. The sample is restricted to the GTAP countries. Data on bilateral tariffs for manufacturing sectors are taken from UNCTAD's TRAINS database. The database can be accessed via the World Bank's World Integrated Trade Solution (WITS) project, https://wits.worldbank.org. The full regression output is relegated to Tables A2 and A3 in the online appendix. We use effectively applied tariffs which are aggregated to the GTAP sector classification with import weights. Other trade cost proxies, i.e., bilateral distance and a dummy for contiguity, are obtained from the CEPII distance database.
} 
and $80 \%$ of the variation in bilateral trade volumes. The coefficients on tariffs are highly statistically significant and satisfy the theoretical restriction $\theta^{j} \in(0,1)$. The ranking of sectors in terms of their productivity dispersion seems sensible. Sectors like "Mining", "Petroleum", "Ferrous metals" or "Chemicals" which provide fairly homogenous goods have a low $\theta$, i.e. trade flows react relatively strongly to cost changes. Sectors like "Transport equipment" or "Electronics", on the other hand, have a relatively high $\theta$ which indicates that they provide relatively heterogeneous sectoral varieties. ${ }^{13}$ We find weak evidence that shallow PTAs increase trade, at least in some sectors. In other sectors, the shallow PTA effect is not statistically different from zero. Deep PTAs, on the other hand, increase bilateral trade quite substantially. For example, in the Processed Food industry, the PTA coefficient is 1.564. This implies bilateral trade increases on average by $e^{1.564}-1=380 \%$ in preferential trade agreements. The coefficients on other trade cost proxies are as expected. Distance reduces bilateral trade volumes. A common border, common language and shared colonial past increases trade. ${ }^{14}$

Note that some PTA coefficients are not statistically significant. For the simulations, we take the positive PTA coefficients when their t-statistic exceeds the value of one. ${ }^{15}$

The estimates obtained for productivity dispersion and their ranking are fairly similar with OLS estimation and also using a simple PTA dummy instead of distinguishing two depths of trade liberalization. ${ }^{16}$ The PTA effects obtained from OLS are smaller than the respective IV estimates, in general. This is also true when employing a single PTA dummy and well documented in the literature. Egger et al. (2011), for example, find that unobservable determinants of PTAs typically have a negative effect on bilateral trade

\footnotetext{
${ }^{13}$ The estimates indicate that the agricultural sector has a rather high productivity dispersion. This results from the fact that we have aggregated agriculture, hunting, forestry, and fishing into a single sector.

${ }^{14}$ See Felbermayr et al. (2014) for a brief literature survey on the size of existing PTA estimates.

${ }^{15}$ In the mining and petroleum sectors, the estimated PTA effects are not stable across different specifications and sometimes implausible high, in spite of evidence from Francois et al. (2009) pointing to the opposite. So we chose to set $\delta$ to zero in these two sectors.

${ }^{16}$ Full regression output is provided in Tables A6 to A17 in the online appendix.
} 
volumes. Consequently, OLS estimates of PTA dummies are downward biased.

Table 2 provides gravity results for PTA effects in service sectors. ${ }^{17}$ In general, our estimations can explain between 90 and $97 \%$ of the variation in bilateral service trade flows. Distance seems to be irrelevant for most service sectors. A shared colonial past and a common border, on the other hand, tends to increase service trade. Shallow PTAs do not provide a positive impulse for service trade. The coefficient on the shallow PTA dummy is statistically insignificant in almost all sectors. For the sectors with a statistically significant coefficient, the effect is relatively small. In "Other business service sectors", e.g., a shallow PTA implies about 6\% higher trade volumes. A deep PTA, which typically has provisions on service trade, is trade-enhancing in almost all sectors. The effect is in the order of magnitude of $30 \%$ in most sectors. Since there are no tariffs levied on service trade flows, we cannot identify $\theta^{j}$ in service industries. We instead take an average value from Egger et al. (2012), who estimate a trade cost elasticity for services of 5.959. OLS gravity estimates provide similar results for the service sectors, even though the PTA effects tend to be smaller. ${ }^{18}$

\subsection{Expenditure and Cost Shares}

The remaining parameters, $\alpha, \beta$, and $\gamma$, and the trade shares $\pi$, tariffs $\tau$, and expenditure $X$ are obtained from GTAP. We perfectly match final goods expenditure, the sectoral bilateral trade flows (aggregating intermediate and final goods trade), the cost shares for intermediates and bilateral tariffs. Two adjustments to the data are necessary to align it with the assumptions of the model. The first adjustment relates to different bilateral trade shares between final and intermediate goods trade. The second adjustment concerns the international transport sector.

\footnotetext{
${ }^{17}$ The full regression output is relegated to Tables A4 and A5 in the online appendix.

${ }^{18}$ The regression output is provided in Tables A8 and A9 the online appendix.
} 


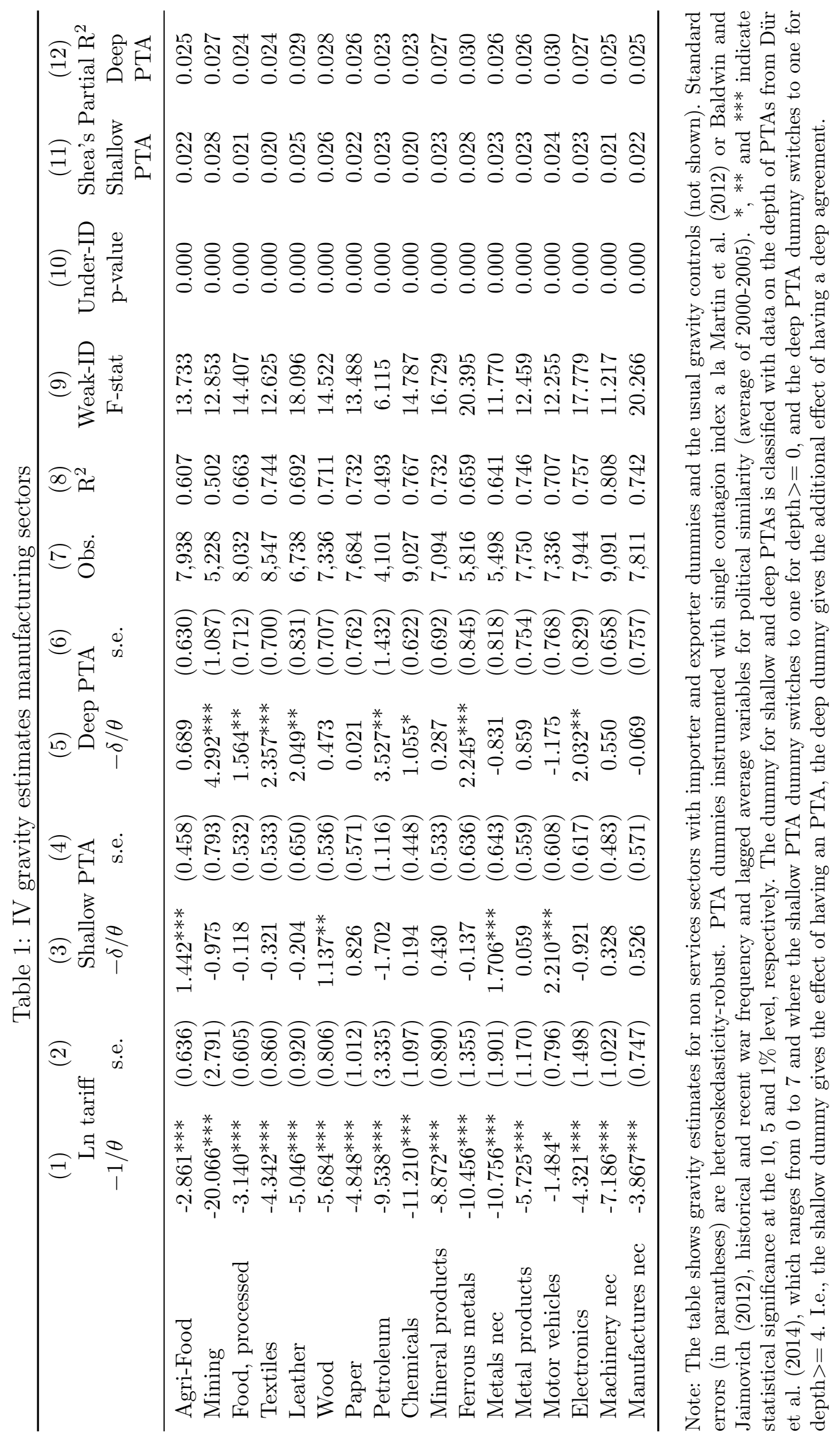




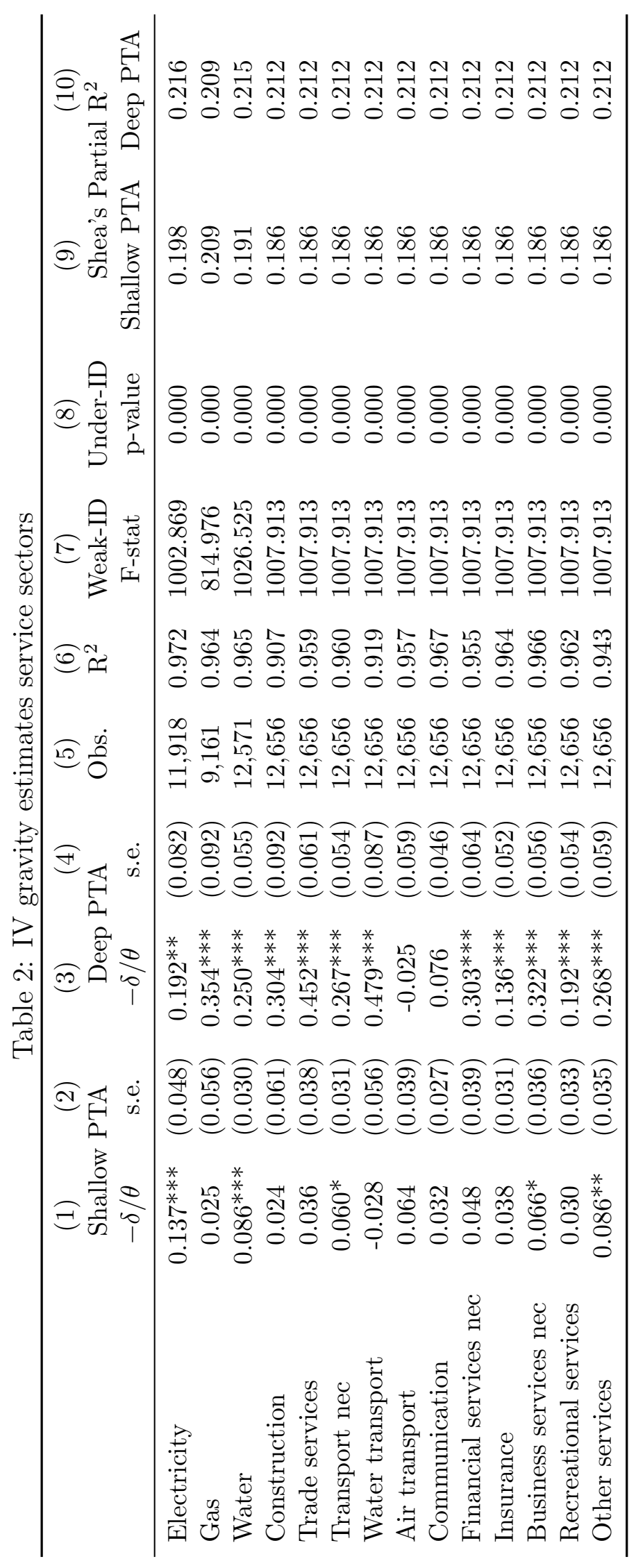

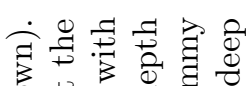

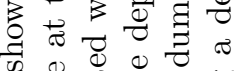

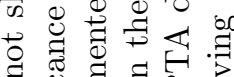

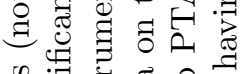

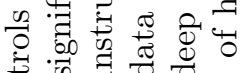

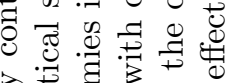

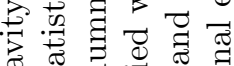

क⿺辶大

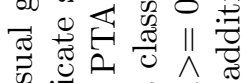

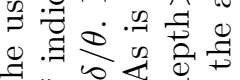

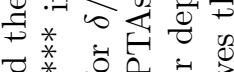

*艹

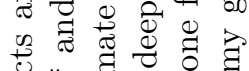

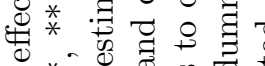

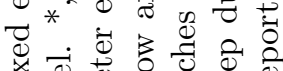

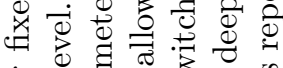

प

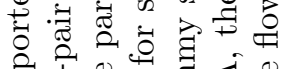

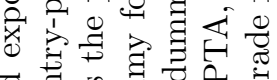

च

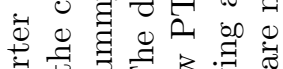

‡

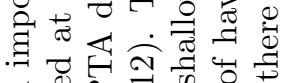

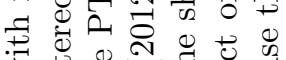

उ

곤

उ

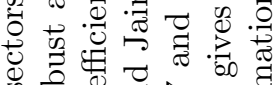

क

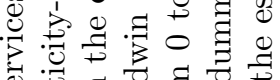

苟

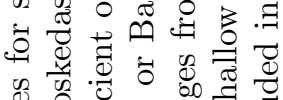

y क

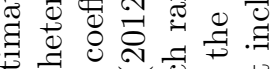

के

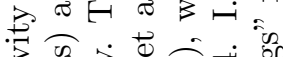

क्षे

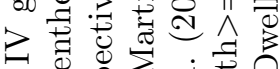

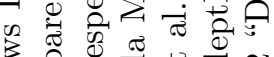

ठ

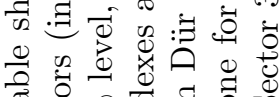

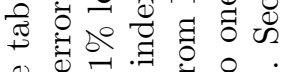

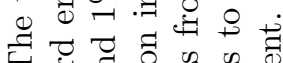

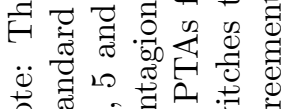

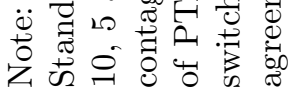


In the model, the bilateral trade shares are assumed to be identical across use. In the GTAP data, however, bilateral trade shares differ across final and intermediate usage. We match sectoral bilateral trade flows, final goods expenditure shares, and cost shares for intermediates to their empirical counterpart and bilateralize final and intermediate goods trade with the common bilateral trade share. And GTAP has a separate international transportation sector. To match the iceberg trade cost assumption, we assign the international transport margin and its respective share of intermediate demand to the sector demanding the international transportation service. This increases the respective sector's production value. The sectoral value added is calculated as the difference between the so obtained production value and intermediate costs. ${ }^{19}$

\section{Simulation results: Trade and Welfare Effects of TTIP}

We now have paved the way to simulate the effect of PTAs in general equilibrium. The setup allows to explore different scenarios: from a tariffs-only liberalization in selected sectors (e.g., excluding services and agriculture), to a deep PTA encompassing all 32 industries. We apply the framework to the case of the TTIP. We first review some important facts; then we analyze trade creation and diversion. Does TTIP strengthen the transatlantic production network? Then we describe the predicted sectoral value added changes and discuss whether comparative advantage plays a role in shaping sectoral responses to our trade policy shock. Last, we investigate the welfare changes under TTIP. The base scenario is a deep TTIP. However, we also characterize the welfare changes in different scenarios such as deep vs. shallow TTIP, no spillovers vs. spillovers, and we also investigate the interactions of TTIP with a round of multilateral trade liberalization. In

\footnotetext{
${ }^{19}$ This implies that production taxes are part of value added.
} 
the online appendix, we also provide some sensitivity checks pertaining to the parameter estimates, i.e. OLS vs. IV estimation and a single PTA dummy vs. two levels of PTA depth.

\subsection{Cross-industry facts for the EU and the US}

Tables 3 and 4 provide information on the status quo of trade between the EU and the US for 32 industries. All values are in US dollars and relate to the base year of $2007 .{ }^{20}$ Column (1) of Table 3 reports for the EU the value added generated in each sector. $73 \%$ of total value added (GDP) is generated in the services sectors, 25\% in manufacturing, and $2 \%$ in agriculture. Columns (2) and (3) shows that total EU exports to the US amount to $465 \mathrm{bn}$. US dollars; this amounts to about $8 \%$ of total exports to non-EU countries. However, in value added terms, the exports of $428 \mathrm{bn}$. US dollars amount to almost $11 \%$ of the total. ${ }^{21}$ This signals that EU exports to the US incorporate relatively little reexports of foreign (including of the US) value added. Column (4) provides tradeweighted sector-level tariff rates that EU exports encounter in the US. Tariffs are low; the average rate (excluding services trade) is just 1.35\%. Exports to the world encounter very similar tariff rates; thus, earlier rounds of (multilateral) trade liberalization have not particularly favored EU exports to the US. Columns (5) and (6) report EU exports to the world. This shows that the US is a particularly important market for EU services exporters: in this area the share of exports going to the US usually exceeds the $11 \%$ overall average (in VA terms) by a wide margin. The opposite is true in agri-food. The manufacturing industries mostly are below the $11 \%$ average, with a few exceptions, most notably Chemicals.

Table 4 provides information for the US side. It shows that the weight of the services

\footnotetext{
${ }^{20}$ This is the most recent year for which input-output data for 134 countries/regions is available. We do not predict baseline values for some future year, as Fontagné et al. (2013) or Francois et al. (2013), since this would introduce additional margins of error.

${ }^{21}$ European value added embodied in US absorption.
} 
Table 3: Status quo summary statistics EU27

\begin{tabular}{lccccccc}
\hline \multirow{2}{*}{ Sector } & $(1)$ & $(2)$ & $(3)$ & $(4)$ & \multicolumn{2}{c}{$(5)$} & \multicolumn{2}{c}{$(6)$} & $(7)$ \\
& Value & \multicolumn{2}{c}{ Exports to US } & \multicolumn{2}{c}{ Exports to World* } \\
& added & Gross & VA & Tariffs & Gross & VA & Tariffs \\
& \multicolumn{2}{c}{ (in bn. USD) } & & (in $\%)$ & (in bn. & USD) & (in \%) \\
\hline Agri-Food & 369 & 2 & 5 & 3.43 & 148 & 117 & 1.82 \\
Mining & 117 & 3 & 9 & 0.03 & 65 & 71 & 0.00 \\
Food, processed & 469 & 17 & 9 & 3.23 & 262 & 124 & 3.12 \\
Textiles & 177 & 7 & 5 & 8.08 & 168 & 80 & 8.61 \\
Leather & 45 & 3 & 2 & 7.43 & 48 & 23 & 10.57 \\
Wood & 94 & 5 & 4 & 0.43 & 106 & 51 & 0.27 \\
Paper & 272 & 5 & 8 & 0.01 & 138 & 101 & 0.00 \\
Petroleum & 180 & 16 & 11 & 1.26 & 133 & 84 & 0.67 \\
Chemicals & 549 & 71 & 45 & 1.13 & 863 & 385 & 1.08 \\
Mineral products & 160 & 6 & 5 & 4.76 & 79 & 53 & 2.88 \\
Ferrous metals & 109 & 7 & 7 & 0.16 & 187 & 81 & 0.18 \\
Metals nec & 56 & 7 & 5 & 1.78 & 129 & 44 & 0.58 \\
Metal products & 287 & 7 & 13 & 1.96 & 154 & 139 & 1.38 \\
Motor vehicles & 382 & 65 & 26 & 0.86 & 774 & 240 & 0.59 \\
Electronics & 146 & 12 & 9 & 0.28 & 261 & 100 & 0.31 \\
Machinery nec & 690 & 80 & 47 & 0.81 & 933 & 422 & 0.75 \\
Manufactures nec & 129 & 14 & 7 & 0.77 & 79 & 40 & 0.73 \\
Electricity & 268 & 0 & 8 & 0.00 & 28 & 85 & 0.00 \\
Gas & 21 & 0 & 1 & 0.00 & 2 & 6 & 0.00 \\
Water & 40 & 0 & 1 & 0.00 & 1 & 7 & 0.00 \\
Construction & 1203 & 1 & 5 & 0.00 & 43 & 64 & 0.00 \\
Trade services & 1107 & 5 & 12 & 0.00 & 129 & 129 & 0.00 \\
Transport nec & 523 & 14 & 20 & 0.00 & 106 & 165 & 0.00 \\
Water transport & 20 & 0 & 1 & 0.00 & 52 & 16 & 0.00 \\
Air transport & 80 & 17 & 7 & 0.00 & 113 & 46 & 0.00 \\
Communication & 374 & 5 & 10 & 0.00 & 49 & 86 & 0.00 \\
Financial services nec & 501 & 22 & 22 & 0.00 & 114 & 133 & 0.00 \\
Insurance & 145 & 21 & 10 & 0.00 & 60 & 34 & 0.00 \\
Business services nec & 3569 & 34 & 90 & 0.00 & 438 & 829 & 0.00 \\
Recreational services & 508 & 5 & 7 & 0.00 & 66 & 73 & 0.00 \\
Other services & 2793 & 14 & 15 & 0.00 & 52 & 82 & 0.00 \\
Dwellings & 328 & 0 & 2 & 0.00 & 0 & 17 & 0.00 \\
\hline Total & 465 & 428 & 1.35 & 5,780 & 3,929 & 1.30 \\
\hline & & & & & & \\
\hline
\end{tabular}

Note: The table shows the EU27's sectoral value added, exports and value added exports to the US and the world in the benchmark year 2007, and the respective tariffs; data source is GTAP 8.1. Tariffs are effectively applied tariffs. Tariffs w.r.t. world are trade weighted-averages. Total tariffs refer to a trade-weighted sum of manufacturing tariffs.

* EU exports to World exclude intra-EU trade. 
Table 4: Status quo summary statistics USA

\begin{tabular}{|c|c|c|c|c|c|c|c|}
\hline \multirow{3}{*}{ Sector } & \multirow{3}{*}{$\begin{array}{c}(1) \\
\text { Value } \\
\text { added } \\
\quad \text { in b }\end{array}$} & \multirow{2}{*}{\multicolumn{3}{|c|}{$\begin{array}{l}(2) \quad(3) \\
\text { Exports to EU27 }\end{array}$}} & \multirow{2}{*}{\multicolumn{3}{|c|}{$\begin{array}{l}(5) \quad(6) \\
\text { Exports to World }\end{array}$}} \\
\hline & & & & & & & \\
\hline & & $\begin{array}{l}\text { Gross } \\
\text {. USD }\end{array}$ & VA & $\begin{array}{l}\text { Tariffs } \\
\text { (in \%) }\end{array}$ & $\begin{array}{l}\text { Gross } \\
\text { (in bn. }\end{array}$ & $\begin{array}{c}\mathrm{VA} \\
\text { USD) }\end{array}$ & $\begin{array}{l}\text { Tariffs } \\
\text { (in \%) }\end{array}$ \\
\hline Agri-Food & 187 & 7 & 5 & 5.60 & 70 & 37 & 7.07 \\
\hline Mining & 167 & 4 & 11 & 0.00 & 17 & 41 & 0.00 \\
\hline Food, processed & 204 & 4 & 2 & 12.01 & 35 & 17 & 10.82 \\
\hline Textiles & 77 & 2 & 2 & 7.65 & 17 & 9 & 5.96 \\
\hline Leather & 6 & 0 & 0 & 3.95 & 2 & 1 & 6.27 \\
\hline Wood & 116 & 2 & 2 & 1.70 & 11 & 9 & 0.74 \\
\hline Paper & 212 & 4 & 7 & 0.01 & 29 & 29 & 0.01 \\
\hline Petroleum & 27 & 12 & 2 & 1.95 & 59 & 6 & 0.32 \\
\hline Chemicals & 351 & 55 & 32 & 2.09 & 190 & 104 & 1.53 \\
\hline Mineral products & 66 & 2 & 2 & 3.11 & 10 & 9 & 2.66 \\
\hline Ferrous metals & 58 & 2 & 4 & 0.45 & 19 & 17 & 0.21 \\
\hline Metals nec & 36 & 8 & 5 & 1.57 & 35 & 14 & 0.87 \\
\hline Metal products & 148 & 5 & 7 & 2.13 & 24 & 27 & 1.69 \\
\hline Motor vehicles & 247 & 47 & 17 & 3.28 & 203 & 63 & 3.95 \\
\hline Electronics & 69 & 19 & 5 & 0.55 & 95 & 18 & 1.40 \\
\hline Machinery nec & 474 & 49 & 31 & 1.22 & 232 & 128 & 1.22 \\
\hline Manufactures nec & 40 & 6 & 3 & 1.04 & 20 & 8 & 1.10 \\
\hline Electricity & 178 & 0 & 4 & 0.00 & 1 & 15 & 0.00 \\
\hline Gas & 57 & 0 & 1 & 0.00 & 1 & 5 & 0.00 \\
\hline Water & 59 & 0 & 1 & 0.00 & 0 & 3 & 0.00 \\
\hline Construction & 882 & 2 & 5 & 0.00 & 6 & 19 & 0.00 \\
\hline Trade services & 1804 & 4 & 26 & 0.00 & 17 & 96 & 0.00 \\
\hline Transport nec & 259 & 13 & 12 & 0.00 & 30 & 37 & 0.00 \\
\hline Water transport & 22 & 0 & 1 & 0.00 & 2 & 3 & 0.00 \\
\hline Air transport & 81 & 11 & 5 & 0.00 & 27 & 15 & 0.00 \\
\hline Communication & 297 & 5 & 6 & 0.00 & 11 & 16 & 0.00 \\
\hline Financial services nec & 1032 & 22 & 26 & 0.00 & 46 & 73 & 0.00 \\
\hline Insurance & 296 & 3 & 4 & 0.00 & 17 & 16 & 0.00 \\
\hline Business services nec & 1439 & 38 & 54 & 0.00 & 92 & 160 & 0.00 \\
\hline Recreational services & 467 & 7 & 5 & 0.00 & 28 & 17 & 0.00 \\
\hline Other services & 3187 & 17 & 15 & 0.00 & 64 & 55 & 0.00 \\
\hline Dwellings & 1258 & 0 & 0 & 0.00 & 0 & 0 & 0.00 \\
\hline Total & 13,800 & 351 & 299 & 2.24 & 1,412 & 1,069 & 2.10 \\
\hline
\end{tabular}

Note: The table shows the USA's sectoral value added, exports and value added exports to the EU27 and the world in the benchmark year 2007, and the respective tariffs; data source is GTAP 8.1. Tariffs are effectively applied tariffs. Tariffs w.r.t. world are trade weighted-averages. Total tariffs refer to a trade-weighted sum of manufacturing tariffs. 
industries in GDP is even more important for the US than for the EU (82\%), but that the agri-food area contributes even less (1\%). Moreover, the levels of GDP are similar, with the EU having a slight advantage. The US is more closed; domestic value added embodied in foreign absorption relative to GDP amounts to $8 \%$; in the EU the number stands at about 25\%. The EU has a bilateral surplus with the US of 114 bn. USD in gross terms and of 129 bn. USD in value added terms. This signals that EU value added is exported to the US via third countries, e.g., Canada or China. Exports to the EU are relatively more important for the US than exports to the US for the EU. US tariffs appear slightly higher than EU tariffs, but the correlation between the two tariff schedules is relatively high (about 61\%).

\subsection{Global trade effects of a deep TTIP}

Reflecting the official ambitions for the TTIP, our scenario assumes that all transatlantic tariffs are eliminated and costs of NTMs fall to the level observed in other deep PTAs. ${ }^{22}$ Moreover, we do not allow the agreement to affect trade costs in non-TTIP country pairs, i.e., we abstract from regulatory spillovers. In this case, the volume of international trade increases from 15.3 to $16.4 \mathrm{tn}$. US dollars ${ }^{23}$, i.e. aggregate trade grows by about $7.3 \%$, see also Table 5. Manufacturing trade (about $80 \%$ of the initially observed trade volume) increases by $7.8 \%$, trade in agricultural goods even by $12.9 \%$, whereas the growth rate in services trade is only $3.5 \%$. So with TTIP, the share of manufacturing trade increases further (by about 0.46 percentage points) at the expense of the trade in services share which falls by 0.62 percentage points. This seems plausible, since the trade cost reductions are largest in manufacturing.

The impressive trade growth our model predicts might however overstate the value added generated under the TTIP. Trade in intermediates - that are used to produce other

\footnotetext{
${ }^{22}$ We provide sensitivity analysis below.

${ }^{23}$ Note that intra-regional trade in GTAP's "Rest of ..." regions is not included in this figure.
} 
Table 5: Global trade effects of a deep TTIP by broad sector

\begin{tabular}{|c|c|c|c|c|c|c|c|c|}
\hline & (1) & $(2)$ & $(3)$ & (4) & $(5)$ & (6) & $(7)$ & (8) \\
\hline & \multicolumn{3}{|c|}{ Exports } & \multicolumn{3}{|c|}{ Value added exports } & \multicolumn{2}{|c|}{ VAX ratio } \\
\hline & $\begin{array}{l}\text { Initial } \\
\text { (in bn. } \\
\text { USD) }\end{array}$ & $\begin{array}{l}\text { Share } \\
\text { (in \%) }\end{array}$ & $\begin{array}{c}\text { Growth } \\
\text { with TTIP } \\
(\text { in } \%)\end{array}$ & $\begin{array}{l}\text { Initial } \\
\text { (in bn. } \\
\text { USD) }\end{array}$ & $\begin{array}{l}\text { Share } \\
(\text { in } \%)\end{array}$ & $\begin{array}{c}\text { Growth } \\
\text { with TTIP } \\
(\text { in } \%)\end{array}$ & $\begin{array}{l}\text { Initial } \\
\text { (in \%) }\end{array}$ & $\begin{array}{l}\text { With } \\
\text { TTIP } \\
(\text { in \%) } \\
\end{array}$ \\
\hline Agriculture & 466 & 3.0 & 12.9 & 478 & 4.4 & 5.5 & 102.5 & 95.7 \\
\hline Manufacturing & 12,154 & 79.4 & 7.9 & 6,139 & 55.9 & 5.9 & 50.5 & 49.6 \\
\hline Services & 2,690 & 17.6 & 3.5 & 4,358 & 39.7 & 6.1 & 162.0 & 166.0 \\
\hline Total & 15,311 & 100.0 & 7.3 & 10,975 & 100.0 & 5.9 & 71.7 & 70.8 \\
\hline
\end{tabular}

Note: The table shows exports and value added export statistics for agriculture, manufacturing and services on the world level.

traded goods - will lead to a double counting of value added embodied in total trade flows. In the baseline year of 2007, world GDP (or value added) amounts to roughly $53 \mathrm{tn}$. US dollar. Table 5 shows that about 11.0 tn. US dollars or $20.8 \%$ of this value added is generated in one country and ultimately absorbed (i.e. consumed or invested) in another one, i.e. the value added is exported. Comparing recorded trade volumes with value added trade volumes, we find a value added to export (VAX) ratio of $71.7 \%$. So almost $30 \%$ of the trade volume measured at the customs is double-counted value added. With the TTIP, our model predicts value added trade to increase by $11.6 \mathrm{tn}$. US dollar, or about $6 \%$. In value added terms, the world becomes more open with TTIP. About $22 \%$ of the value added is exported, an increase of 1.2 percentage points. But, both in the level as well as in the growth created with the TTIP, world value added trade falls behind world trade. The VAX ratio falls by about 1 percentage points to $70.8 \%$. So the TTIP leads to more double-counting of value added in trade statistics, presumably because it fosters the transatlantic production network (with back-and-forth trade of intermediates).

A decomposition of the total value added trade into manufacturing, services and agricultural value added reveals that services trade is more important than recorded trade flows would suggest. Even though manufacturing value added has the highest share in value added transfers between countries, with $56 \%$ in total traded value added it lies well below the $80 \%$ share of manufacturing trade. The VAX ratio of manufacturing is 
only $50.5 \%$. This indicates that (1) manufacturing trade partly takes place in the form of intermediates trade and that (2) traded manufacturing goods embody value added of the services industries. Indeed, while the recorded services trade is about $2.7 \mathrm{bn}$. USD, the trade in embodied services value added is $4.4 \mathrm{bn}$. USD. So in terms of value added, services account for $40 \%$ of value added trade, against $17 \%$ in recorded trade volumes. The VAX ratio for services is $162 \%$, implying that service value added trade is by $62 \%$ higher than recorded trade. A large fraction of services value added is traded indirectly via the domestic value chain. An example would be domestic accounting or IT services that are embodied in exported cars.

Under the TTIP, agricultural, manufacturing and services value added trade all grow. But whereas recorded manufacturing trade increases by $7.8 \%$, manufacturing value added associated with trade flows only increases by $5.9 \%$ (and starting from a lower level). The reverse happens in services sectors, which grow with $6.1 \%$ in terms of value added trade, compared to only $3.5 \%$ in recorded trade. So, our simulations now suggest that the TTIP will lead to a slight increase in the share of services value added trade of 0.05 percentage points, at the costs of manufacturing (-0.03 percentage points) and agricultural (-0.02 percentage points) value added trade. While the TTIP predominantly fosters manufacturing trade, indirectly, i.e. via domestic supply chains, a lot of the associated value added is generated in the service sectors and not in manufacturing. Given that both liberalizing regions, the US and the EU, are mature economies with a large share of value added in services, this may not come as a surprise. The VAX ratio in agriculture is roughly $103 \%$ in the initial situation; with the TTIP it falls to $96 \%$. The US has a comparative advantage in agriculture and increases its agricultural exports. In the US, agriculture uses more services inputs than the average country. This explains why the agricultural VAX ratio goes down with TTIP. 
Table 6: Aggregate trade effects of deep TTIP

\begin{tabular}{|c|c|c|c|c|c|c|c|c|c|c|}
\hline Region & $\begin{array}{c}(1) \\
\text { ASEAN }^{b}\end{array}$ & $\begin{array}{c}(2) \\
\text { Brazil }\end{array}$ & $\begin{array}{c}(3) \\
\text { Canada }\end{array}$ & $\begin{array}{c}(4) \\
\text { China }\end{array}$ & $\begin{array}{c}(5) \\
\text { EU27* }\end{array}$ & $\begin{array}{c}(6) \\
\text { Germany }\end{array}$ & $\begin{array}{c}(7) \\
\text { Mexico }\end{array}$ & $\begin{array}{c}(8) \\
\mathrm{SACU}^{a}\end{array}$ & $\begin{array}{c}(9) \\
\text { Turkey }\end{array}$ & $\begin{array}{l}(10) \\
\text { USA }\end{array}$ \\
\hline \multicolumn{11}{|c|}{ Export growth (in \%) from ... to } \\
\hline $\operatorname{ASEAN}^{b}$ & -1 & -0 & -2 & -3 & -1 & -3 & -3 & -0 & -0 & -7 \\
\hline Brazil & -2 & -1 & -8 & -3 & 0 & 0 & -7 & -2 & 1 & -7 \\
\hline Canada & -1 & 1 & -1 & -1 & -2 & 6 & -4 & 1 & 2 & -8 \\
\hline China & -2 & 1 & -2 & -1 & -1 & -5 & -3 & 1 & 1 & -7 \\
\hline $\mathrm{EU} 27^{*}$ & -6 & -5 & -9 & -6 & -1 & -5 & -7 & -4 & -5 & 171 \\
\hline Germany & -7 & -6 & -9 & -6 & -8 & -1 & -7 & -3 & -4 & 216 \\
\hline Mexico & 0 & 1 & -5 & -1 & 4 & -11 & -1 & 2 & 1 & -6 \\
\hline $\mathrm{SACU}^{a}$ & -3 & -1 & -4 & -4 & 2 & 1 & -4 & -1 & -0 & -11 \\
\hline Turkey & -1 & -1 & -3 & -1 & -4 & -3 & -3 & -0 & -1 & -5 \\
\hline USA & -4 & -3 & -6 & -4 & 212 & 259 & -5 & -2 & 21 & -2 \\
\hline \multicolumn{11}{|c|}{ Growth of value added transfers (in \%) from ... to } \\
\hline $\mathrm{ASEAN}^{b}$ & -1 & 0 & -3 & -1 & 1 & 0 & -4 & -0 & -0 & -6 \\
\hline Brazil & -2 & -1 & -6 & -3 & 0 & 0 & -6 & -1 & -0 & -5 \\
\hline Canada & -0 & 1 & -1 & -1 & 25 & 42 & -4 & 3 & 9 & -9 \\
\hline China & -1 & 1 & -3 & -1 & 2 & 1 & -3 & 1 & 1 & -7 \\
\hline EU27* & -6 & -5 & 7 & -6 & -2 & -7 & 7 & -6 & -7 & 120 \\
\hline Germany & -7 & -6 & 12 & -7 & -10 & -2 & 4 & -6 & -8 & 136 \\
\hline Mexico & 0 & 2 & -6 & 0 & 44 & 33 & -1 & 5 & 13 & -9 \\
\hline $\mathrm{SACU}^{a}$ & -3 & -2 & -5 & -4 & -0 & -0 & -6 & -1 & -0 & -0 \\
\hline Turkey & -2 & -2 & -1 & -3 & -6 & -4 & -2 & -2 & -1 & 21 \\
\hline USA & -2 & -2 & -9 & -3 & 149 & 169 & -8 & 10 & 34 & -2 \\
\hline
\end{tabular}

Note: The table shows bilateral changes in trade flows and value added transfers (in \%) from deep TTIP. The diagonal describes changes in intra-national trade and/or in the trade volume within a region.

${ }^{*}$ EU27 without Germany. ${ }^{a}$ Southern African Customs Union, ${ }^{b}$ Association of Southeast Asian Nations.

\subsection{Bilateral trade effects of a deep TTIP}

While Table 5 offers insights into the evolution of total trade flows under the TTIP, Table 6 looks into its effects on regional trade links. Again, we discuss trade and value added trade changes. Our model predicts a substantial amount of trade creation between the EU and the US in the long run. German and EU exports to the US are expected to roughly triple. And also the US exports to the EU and Germany are expected to go up by 212 and $259 \%$, respectively. However, trade statistics exaggerate the transfer of value added between the two transatlantic economies. German value added exports to the US, e.g., are predicted to increase by $136 \%$ instead of $216 \%$. And also the US export growth with Germany is only $169 \%$ under the TTIP. One explanation for this observed pattern 
is the deepening of transatlantic production chains. Then, the US would process more EU value added in the form of intermediate inputs under the TTIP and vice versa. As a consequence, changes in recorded trade flows would overstate how much value added is generated. We will look into this possibility in more detail in the next section.

Figure 2 shows the EU-US trade changes for four sectors: Agri-Food, Chemicals, Transport equipment and Other Business Services. The blue lines represent kernel density estimates for the bilateral trade changes. Trade between the US and EU countries grows in all sectors. The growth is particularly high for Transport Equipment. This is not unexpected, since tariffs are still relatively high in this sector. Figure 2 also shows a kernel density estimate of the respective bilateral growth rate in value added trade between the EU and US for these sectors. ${ }^{24}$ The two distributions strongly deviate from each other. The pattern is as described for aggregate trade flows. For manufacturing industries, where trade in intermediate inputs is extensive, the growth in value added exports tend to be smaller than the growth in gross exports. For other business services, however, the reverse is true.

We have seen that German exports to the US rise by about $216 \%$. German value added exports, on the other hand, only grow by $136 \%$. This implies that the ratio of value added exports to exports between Germany and the US declines from 0.95 to 0.71 . This can mean two things: (1) The domestic value added content of German goods falls with the TTIP. This is confirmed by looking at the inverse Leontief coefficients. The German value added needed to produce output worth one dollar falls between 0.2 and 4.6 US cents ${ }^{25}$, depending on the sector at hand. (2) Some German value added that is shipped to the US embodied in German exports does not remain in the US, is processed

\footnotetext{
${ }^{24}$ We define the value added export of a sector as the value added generated in this particular sector, i.e. in the source sector. It implies that the sector's value added can reach the absorbing country embodied in the trade flows of other sectors as well as directly.

${ }^{25}$ To begin with, the German value added content of German (final) goods lies between 51 and 84 US cents per USD of output in the manufacturing sector. In service industries, these values are typically higher and lie between 74 and 96 US cents.
} 
Figure 2: Changes in trade and value added trade in EU-US pairs and within EU

(a) Agri-Food, EU-US pairs

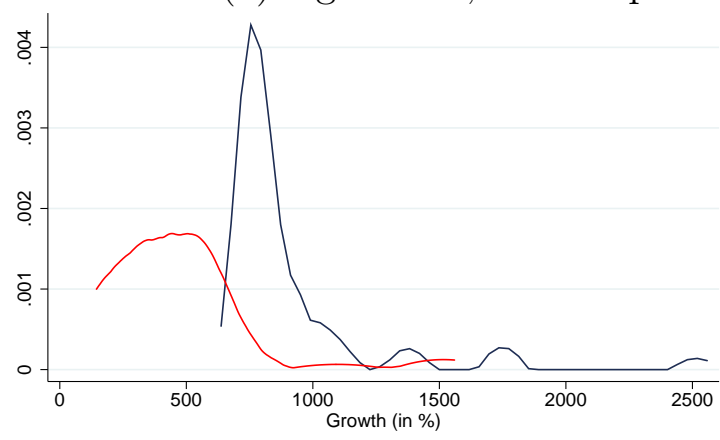

(c) Chemicals, EU-US pairs

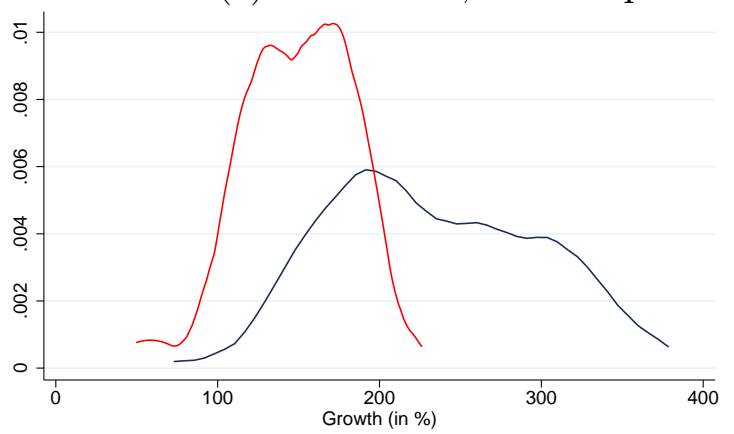

(e) Transport equipment, EU-US pairs (f) Transport equipment, within-EU

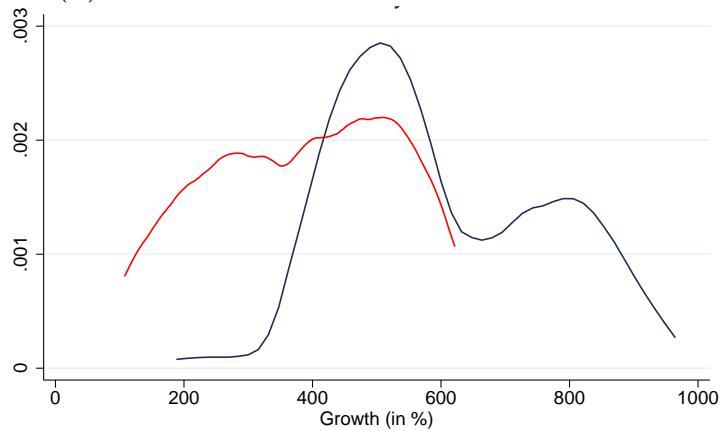

(g) Business serv., EU-US pairs

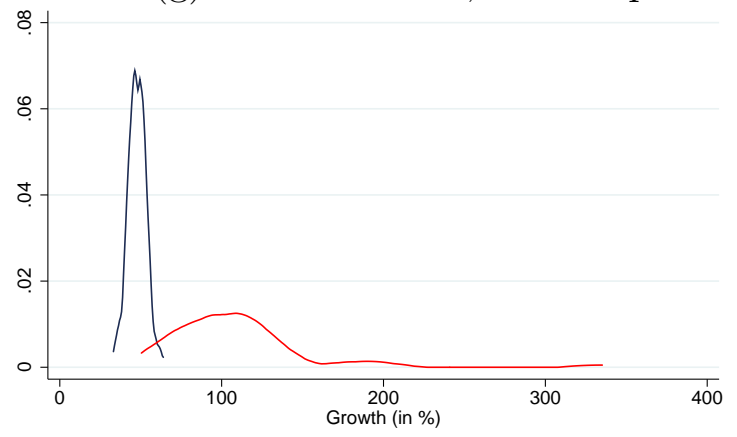

(b) Agri-Food, within-EU

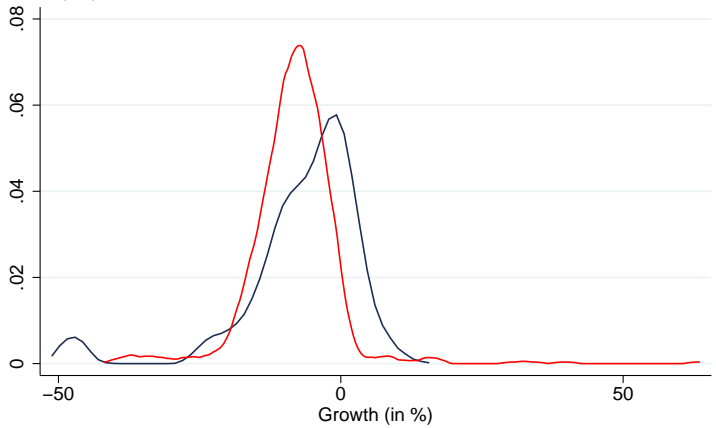

(d) Chemicals, within-EU

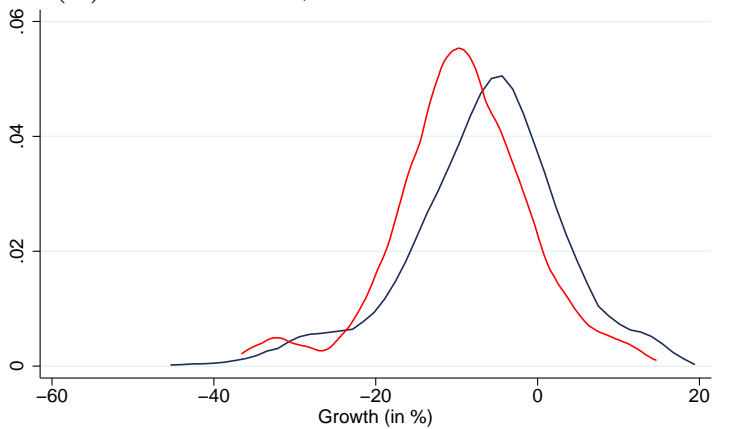

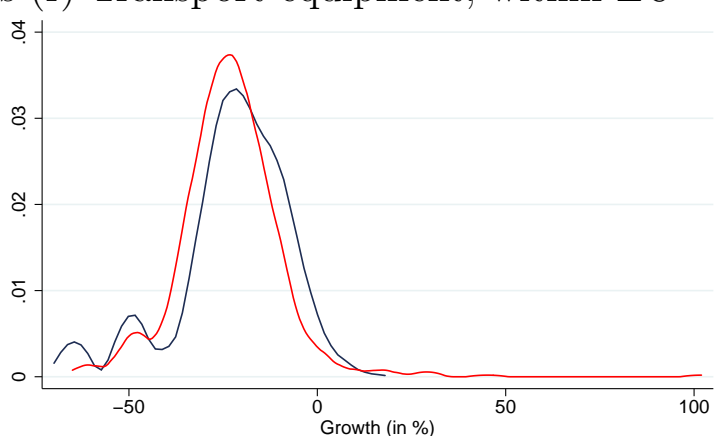

(h) Business serv., within-EU

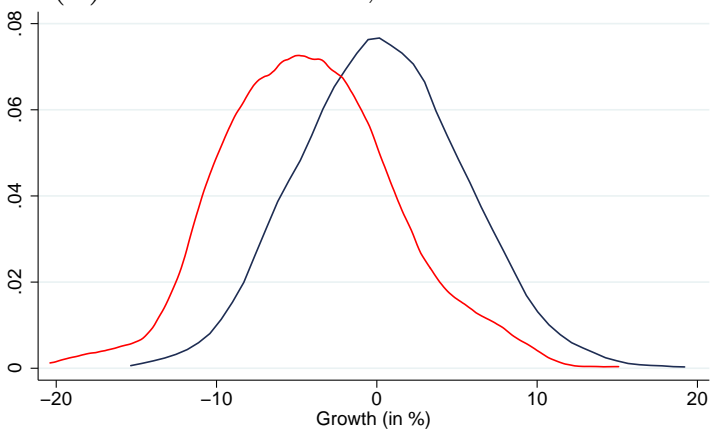

Note: The figure shows kernel density estimates (Epanechnikov, optimal bandwidth) of the changes in trade (blue lines) and value added trade (red lines) for the TTIP scenario of deep trade integration. Trade between EU-US country pairs is displayed in the first column of graphs, within-EU trade is represented in the second column of graphs. The sectors shown are Agri-Food, Chemicals, Transport equipment and Other business services. 
further and finally consumed in a third country (e.g. in other EU countries that also intensify their trading relation with the US). In value added terms, this is counted as German value added export to the third country. In all likelihood, the observed decline in the German-US bilateral VAX ratio is a combination of both effects.

Figure 3 shows the sectoral composition and evolution of Germany's exports to the USA under the TTIP. The sectors are arranged in descending order of their trade volumes. The blue, solid line shows the initial export volumes, the red, solid line the counterfactual export volumes with the TTIP. Germany's most important export good to the US is Machinery, followed by Transport Equipment, Chemicals and Other business services. Although the exports of all sectors increase with the TTIP, there is big sectoral heterogeneity. In some sectors, the growth rates are very high-for example, $513 \%$ for Transport Equipments or $628 \%$ for Electronics - whereas the predicted growth rates are smaller, especially for services industries.

Figure 3 also shows the respective German sectors' value added exports to the US in the initial situation (blue, dashed line) and with TTIP (red, dashed line). Interestingly, in value added terms, the German top export sector is no longer Machinery but Other business services. As discussed earlier, a lot of services value added is traded indirectly. For German business services, for example, the corresponding value added export is roughly 3.5 times higher than the recorded export flow. In these service sectors or also in other upstream sectors, the value added exports growth tends to be substantially higher than the export growth. Again looking at Other business services the export growth is $43 \%$, the respective value added export growth rate, however, is $124 \%$.

In many manufacturing industries, on the other hand, the value added generated by exports to the US is largely exaggerated with export growth statistics. In these sectors, the German value added embodied in exports typically falls quite substantially. For example, in the Transport equipment sector, the initial German value added share is 65 US cents per one USD of output (i.e. 65\%). Compared with other industries, this is already 
Figure 3: Sectoral composition of German exports and value added exports to the US

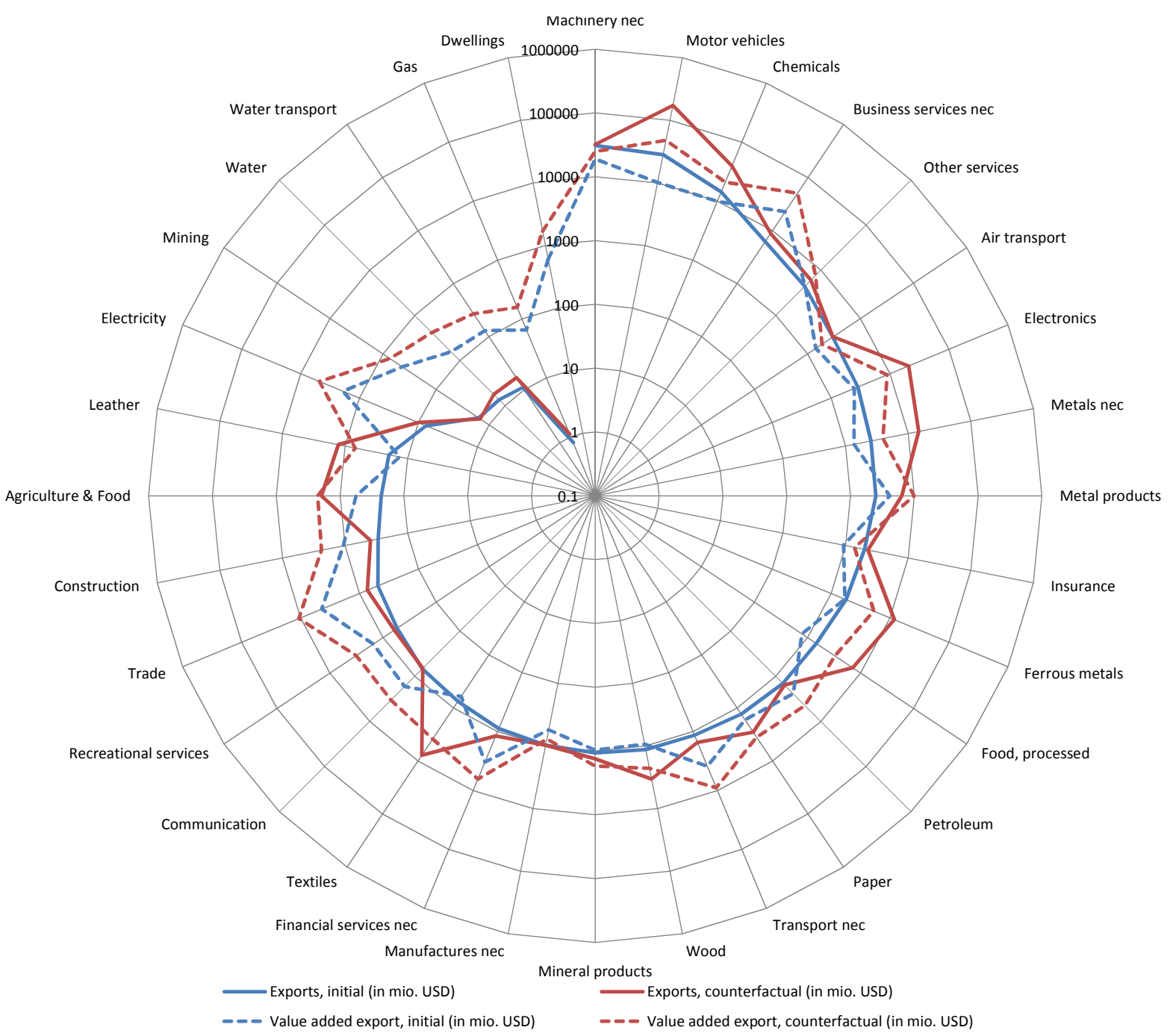

Note: The polar plot shows a sectoral decomposition of the German exports (solid lines) and value added exports (dashed lines) to the USA in the initial situation (blue lines) and in the counterfactual with the TTIP (red lines) on a logarithmic scale with the base 10. The sectors are sorted (clockwise) according to the initial value of exports. The difference between the lines gives the growth rate of exports.

low. With the TTIP, this falls by almost $7 \%$ and reaches a counterfactual level of 61 US cents per USD of output. Consequently, while these sector's exports grow by $513 \%$, the respective value added export growth is only $367 \%$. In other words, Germany increasingly exports value added generated in the transport equipment sector to the US. However, the export growth rate overstates the amount of value added generated in Germany in this 
Figure 4: Sectoral composition of US exports and value added exports to Germany

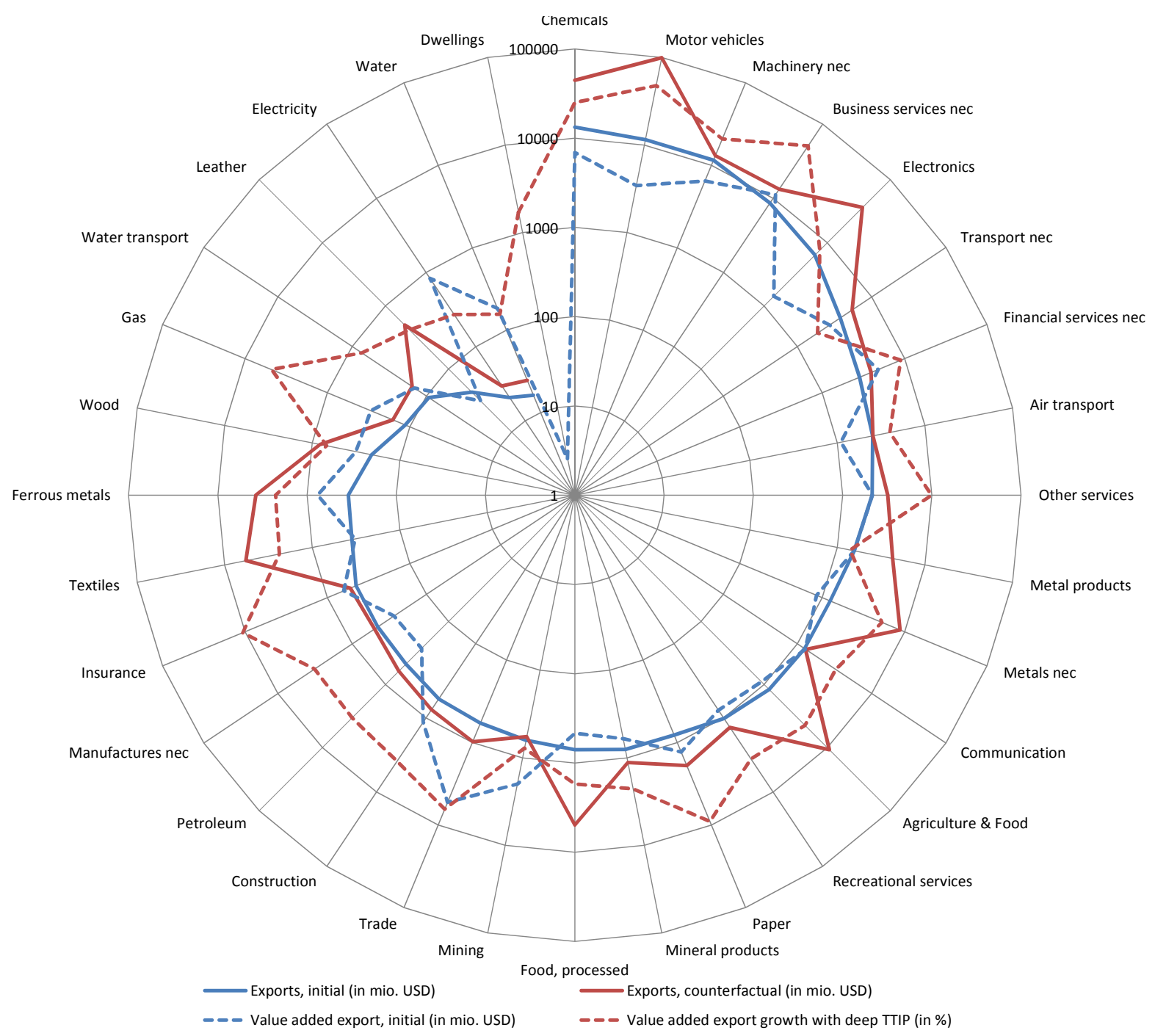

Note: The polar plot shows a sectoral decomposition of the US exports (solid line) and value added exports (dashed lines) to Germany in the initial situation (blue lines) and in the counterfactual with the TTIP (red lines) on a logarithmic scale with the base 10. The sectors are sorted (clockwise) according to the initial value of exports. The difference between the lines gives the growth rate of exports.

way because (1) the value added is generated in upstream sectors like Other business services and (2) the foreign content of the traded goods increases.

Figure 4 shows a similar graph for US exports to Germany.

Table 6 also shows that the TTIP will lead to substantial trade diversion within the EU. Intra-EU trade falls by some $5 \%$. In value added terms, the trade diversion is even more 
pronounced. Value added exports fall by $7 \%$. Figure 2 provides a more disaggregated view for selected sectors. It shows the kernel density estimates of the trade and value added trade changes within the EU. The distribution of value added changes lies to the left of the distribution of recorded trade changes in all shown sectors. This pattern is stronger for more upstream sectors like Chemicals or Other Business Services. Value added trade also captures indirect effects via sectors that use the sector's output as input. So the pattern of bigger reductions in value added terms can be explained either by the fact that other sectors (in Germany or abroad) reduce the usage of the sector's intermediates or that sectors which heavily rely on the sector's inputs have adverse trade effects or that more of the sector's value added does not stay in the EU trade partner but is processed and shipped on (e.g. to the US), or all of the above.

The TTIP will not only lead to trade diversion within the EU. Both the EU and the US are predicted to export less to non-TTIP countries and mostly also import less from non-TTIP countries. In value added terms, however, the picture is more nuanced. In particular, the predicted patterns show how the growing transatlantic production network interacts with the NorthAmerican production network. Even though the EU exports less to Canada (-9\%), Canadian absorption of European value added increases (by $+7 \%$ for EU27 exclusive Germany, and by even $+12 \%$ for Germany). A similar pattern emerges for EU trade with Mexico. So, more EU value added is embodied in US goods, and thus absorbed in Canada and Mexico which trade intensively with the US. Vice versa, the EU increases its absorption of Canadian and Mexican value added. It reaches the EU embodied in US exports. Canadian value added exports to the EU27 exclusive Germany, e.g., increases by $25 \%$, and to Germany by $42 \%$; compared to changes of Canadian exports of -2 and $+6 \%$, respectively.

The EU, on the other hand, has production networks e.g. with Turkey and South Africa. Even though the SACU exports to the US fall by $11 \%$, the SACU value added exports to the US remain constant (i.e. $+0 \%$ ). EU imports from SACU countries increase, 
and so are (partly) indirectly transferred to the US. Another interesting case is the US's trade relationship with Turkey. Turkey is in a currency union with the EU, and so the Turkish import tariffs on US products would fall away with the TTIP. Thus, US exports to Turkey are stimulated and increase by $21 \%$. The asymmetric nature of the Turkish currency union with the EU becomes evident when looking at the Turkish exports to the US. The US does not eliminate its import tariffs on Turkish products with the TTIP, and hence, Turkish exporters suffer from trade diversion on the US market. Turkish exports to the US fall by $5 \%$. But indirectly (presumably via the EU because the input-output linkages between Turkey and the EU are strong), Turkish value added exports to the US grow by $21 \%$.

Last, the TTIP tends to reduce trade flows between third countries. But in some cases, it will lead to trade creation between third countries, such as, e.g., between China and Brazil. This general ambiguity is due to the joint effects of two opposing facts: first, as incomes in third countries fall, demand for imports generally decline; second, trade may rise as exports that went to the EU or the US in the baseline situation are redirected.

Summarizing, trade and value added trade changes mostly follow similar patterns. However, there are some important exceptions where recorded and value added trade flows change nonproportionally or even go in different directions. This is the result of newly forming or existing international production chains.

The described trade changes have important implications for the openness of countries. Our data set allows us to describe changes in countries' openness in value added terms. How does the TTIP affect the amount of foreign value added contained in domestic absorption? In the US, the initial foreign value added share in domestic absorption is 12.8\%. With the TTIP, the absorption of foreign value added increases by almost a quarter to $15.8 \%$. So the US becomes more open with the TTIP. In the EU, the foreign 
value added share in absorption is higher to start with. The EU average is $26 \%{ }^{26}$ It is lowest in France (21\%), and highest in Malta (70\%). With a foreign value added share of $26 \%$, Germany lies well within the EU average. With the TTIP, the EU on average increases the foreign value added share by 6.5\%. Germany and the UK (both $9 \%$ ) experience the largest increases of foreign value added absorption. On the other end of the within-EU distribution are Slovenia, Estonia and the Czech Republic with an increase of below $0.5 \%$.

While the foreign value added in absorption increases in the TTIP countries, it falls by $1.3 \%$, on average, in non-TTIP countries. The reductions are largest for Canada $(-3.1 \%)$, Mexico (-2.6\%), and Japan (-2.4\%); while in some African, non-EU European and Central Asian countries the foreign value added in domestic absorption increases slightly. So, in general, non-TTIP countries tend to become less open.

\subsection{Bilateral trade balances}

Missing an intertemporal savings-investment tradeoff, the model fixes multilateral trade imbalances to the initial situation. However, in the counterfactual situation, the structure of trade imbalances will change. With the TTIP, the US increases its trade deficit with the EU from 118.4 bn. USD (of which 43.5 with Germany) to $179.0 \mathrm{bn}$. USD. ${ }^{27}$ This is a long-term increase of more than $40 \mathrm{bn}$. USD. The US deficit with the SACU region and the oil exporting countries also increases. On the other hand, the US deficit with most other regions is reduced. For example, the deficit with Canada is reduced by 9.4 bn. USD, the one with the Pacific Alliance countries by $6.3 \mathrm{bn}$. USD. Furthermore, the deficit with Asian countries, in particular China ( +22 bn. USD), East Asia (+18 bn. USD), ASEAN $(+7$ bn. USD) and South Asia ( +4 bn. USD) is cut substantially. The same pattern emerges for the US bilateral deficit in value added transfers.

\footnotetext{
${ }^{26}$ This is a weighted average, where the country's total absorption is used as weight.

${ }^{27}$ To construct the trade balances, imports are valued inclusive of tariffs.
} 
Germany increases its trade surplus to the US by 46 bn. USD after the introduction of TTIP (from 34.4 to 80.3 bn. USD). The trade deficit with East Asia and also with China is reduced, albeit by 124 and 295 mio. USD only. With most other regions, Germany has a trade surplus. This surplus is cut substantially with the other EU27 countries (-29 bn. USD) and also with most other regions. In value added terms, the German surplus with the US increases less (42 instead of $46 \mathrm{bn}$. USD). So the regular trade surplus overstates the increasing imbalance.

\subsection{The transatlantic production network}

In this section, we analyze the transatlantic production network in more detail. We focus on the trade relation between the two biggest Atlantic economies, Germany and the US. To capture the effects along the total world production chain, we focus on value added flows. The Leontief logic allows to single out for each final goods trade between two countries, how much value added is generated in each source country and sector. Thus, the production networks can be analyzed coming from two different angles (see also Aichele and Heiland, 2014). First, we can ask through which final goods producing countries German value added reaches the US. Second, we can ask from which regions the value added stems that Germany processes into final goods exports to the US. The first method investigates the (final) route German value added takes into the US, while the second method highlights the sourcing structure of the German economy.

German value added exports to the US rise by $136 \%$. Table 7 summarizes via which final goods producing regions, i.e. processing region, the German value added reaches the US consumers. Column (1) shows that, in the initial situation, almost $40 \mathrm{bn}$. USD of German value added reaches the US embodied in German final goods exports to the US. An even more substantial part reaches the US via products that are finally assembled in the US (roughly 50 bn. US dollars). This captures that Germany may export intermediates to the US or other countries, which in turn export final or intermediate 
Table 7: German value added flows to US via different processing regions

\begin{tabular}{|c|c|c|c|c|c|c|}
\hline \multirow{3}{*}{ Processing region } & (1) & $(2)$ & $(3)$ & $(4)$ & $(5)$ & (6) \\
\hline & \multicolumn{3}{|c|}{ VA flow (in Mio USD) } & \multicolumn{3}{|c|}{ VA flow, growth rate (in \%) } \\
\hline & Initial & $\begin{array}{r}\text { With TTIP, } \\
\text { initial sourcing } \\
\text { structure }\end{array}$ & $\begin{array}{l}\text { With } \\
\text { TTIP }\end{array}$ & $\begin{array}{l}\text { Scale } \\
\text { effect }\end{array}$ & $\begin{array}{r}\text { Sourcing } \\
\text { effect }\end{array}$ & $\begin{array}{l}\text { Total } \\
\text { effect }\end{array}$ \\
\hline USA & 52,588 & 49,894 & 106,270 & -5 & 113 & 102 \\
\hline Germany & 38,175 & 121,985 & 115,867 & 220 & -5 & 204 \\
\hline EU27 & 6,506 & 23,285 & 19,807 & 258 & -15 & 204 \\
\hline China & 1,826 & 1,679 & 1,585 & -8 & -6 & -13 \\
\hline East Asia & 1,503 & 1,192 & 1,149 & -21 & -4 & -24 \\
\hline Canada & 1,311 & 965 & 1,216 & -26 & 26 & -7 \\
\hline Pacific Alliance & 1,065 & 886 & 967 & -17 & 9 & -9 \\
\hline $\mathrm{ASEAN}^{d}$ & 976 & 901 & 868 & -8 & -4 & -11 \\
\hline $\mathrm{EFTA}^{b}$ & 747 & 703 & 672 & -6 & -4 & -10 \\
\hline $\mathrm{MENA}^{c}$ & 401 & 377 & 351 & -6 & -7 & -12 \\
\hline South Asia & 167 & 149 & 139 & -11 & -7 & -17 \\
\hline MERCOSUR & 114 & 94 & 90 & -17 & -5 & -21 \\
\hline Eurasian Customs Union & 81 & 77 & 72 & -5 & -6 & -11 \\
\hline $\mathrm{SACU}^{a}$ & 70 & 57 & 54 & -18 & -6 & -23 \\
\hline Latin America \& Caribbean & 66 & 60 & 64 & -10 & 7 & -3 \\
\hline Australia \& New Zealand & 57 & 54 & 50 & -6 & -6 & -11 \\
\hline Turkey & 44 & 37 & 34 & -15 & -8 & -21 \\
\hline Oil exporters & 40 & 40 & 38 & 0 & -5 & -5 \\
\hline Sub-Saharan Africa & 36 & 35 & 33 & -3 & -6 & -9 \\
\hline Central Asia & 28 & 25 & 24 & -9 & -6 & -15 \\
\hline Rest of Europe & 27 & 25 & 24 & -8 & -5 & -13 \\
\hline Rest of World & 16 & 15 & 14 & -7 & -6 & -13 \\
\hline Oceania & 5 & 5 & 5 & -0 & -8 & -8 \\
\hline
\end{tabular}

Note: The table shows German value added flows to the US via different processing regions, i.e. final goods exporters. Scale effect: VA growth going from initial to deep TTIP, but keeping sourcing structure (i.e. Leontief coefficients) as in initial situation. The scale effect corresponds to the export growth of the processing region with the US. Sourcing effect: VA growth going from deep TTIP with initial sourcing structure to deep TTIP with new sourcing structure (i.e. counterfactual Leontief coefficients). It shows the effect of changes in the supply chains. Total effect: total VA growth going from initial to deep TTIP.

${ }^{a}$ Southern African Customs Union, ${ }^{b}$ European Free Trade Association, ${ }^{c}$ Middle East \& North Africa, ${ }^{d}$ Association of Southeast Asian Nations.

goods for further processing to the US. Under the same logic, other EU countries' exports also contain German value added of around $6.5 \mathrm{bn}$. USD. TTIP now leads to intensified transatlantic trade. German exports to the US roughly triple; those of other EU27 countries, on average, increase by $170 \%$. Keeping the sourcing structure constant (i.e. fixing the Leontief inverse coefficient in the baseline and only increasing final goods trade flows to their counterfactual value), this scale effect implies that more German value added 
reaches the US via German exports, but also via final goods exports of other EU countries to the US. The scale effect also shows trade diversion; the US trades less with all non-EU regions including itself, and this implies less German value added (that is used to produce the other regions' goods) reaches the US via other regions. The intra US trade also falls by about $6 \%$. But in GE, the sourcing structure adjusts with the TTIP. The US has more imports from the EU, and in part uses them as inputs to produce its own goods. Therefore, the US sourcing effect in column (5) is positive. More German value added reaches the US consumers embodied in US final goods because they use more German, and generally EU inputs (which also contain considerable amounts of German value added). The sourcing effect is negative for most other regions. Trade diversion implies that non-TTIP regions use less TTIP inputs to produce their output. However, Canada, the Pacific Alliance and Latin America display a positive sourcing effect. These regions all trade a lot with the US and are an integral part of the North American production network. Since the US uses more German (and EU) products as inputs, these countries indirectly also source more value added from Germany via the US.

Overall, German value added increasingly reaches the US via final goods exports of Germany and the other EU countries as well as intra-USA trade. In other words, the TTIP strengthens the transatlantic production network.

Table 8 looks into the sourcing structure of the German economy. Initially, roughly $52 \mathrm{bn}$. USD of value added reach the US consumers via final goods exports of Germany. The largest share, about three quarters, is value added generated in Germany itself. This indicates that the domestic value chain is still predominant. Other EU countries, the USA, East Asia, EFTA countries and China are also important source countries. The substitution and income effect leads to more US final goods imports from Germany. Thus, keeping the sourcing structure constant, the value added sourced in all regions and processed in Germany for US consumers increases. The effect is not uniform across all source countries due to sectoral heterogeneity. This depends on how important the source 
Table 8: Value added flows to US with final processing in Germany

\begin{tabular}{|c|c|c|c|c|c|c|}
\hline \multirow{3}{*}{ VA source country } & (1) & $(2)$ & $(3)$ & $(4)$ & $(5)$ & (6) \\
\hline & \multicolumn{3}{|c|}{ VA flow (in Mio USD) } & \multicolumn{3}{|c|}{ VA flow, growth rate (in \%) } \\
\hline & Initial & $\begin{array}{r}\text { With TTIP, } \\
\text { initial sourcing } \\
\text { structure }\end{array}$ & $\begin{array}{l}\text { With } \\
\text { TTIP }\end{array}$ & $\begin{array}{l}\text { Scale } \\
\text { effect }\end{array}$ & $\begin{array}{r}\text { Sourcing } \\
\text { effect }\end{array}$ & $\begin{array}{l}\text { Total } \\
\text { effect }\end{array}$ \\
\hline Germany & 38,175 & 121,985 & 115,867 & 220 & -5 & 204 \\
\hline EU27 & 7,022 & 27,887 & 23,791 & 297 & -15 & 239 \\
\hline USA & 1,163 & 4,655 & 15,691 & 300 & 237 & 1249 \\
\hline East Asia & 867 & 3,483 & 3,142 & 302 & -10 & 263 \\
\hline $\mathrm{EFTA}^{b}$ & 778 & 2,634 & 2,401 & 239 & -9 & 209 \\
\hline China & 744 & 2,741 & 2,725 & 269 & -1 & 266 \\
\hline Eurasian Customs Union & 717 & 2,487 & 2,321 & 247 & -7 & 224 \\
\hline $\mathrm{ASEAN}^{d}$ & 340 & 1,273 & 1,224 & 275 & -4 & 260 \\
\hline $\mathrm{MENA}^{c}$ & 329 & 1,169 & 1,145 & 256 & -2 & 248 \\
\hline MERCOSUR & 230 & 898 & 880 & 291 & -2 & 283 \\
\hline Pacific Alliance & 229 & 965 & 1,097 & 321 & 14 & 379 \\
\hline Oil exporters & 224 & 834 & 846 & 273 & 1 & 278 \\
\hline Turkey & 175 & 780 & 650 & 345 & -17 & 271 \\
\hline South Asia & 136 & 544 & 538 & 301 & -1 & 296 \\
\hline Canada & 128 & 500 & 781 & 290 & 56 & 509 \\
\hline Sub-Saharan Africa & 112 & 410 & 441 & 266 & 8 & 294 \\
\hline $\mathrm{SACU}^{a}$ & 110 & 424 & 389 & 284 & -8 & 252 \\
\hline Central Asia & 108 & 387 & 361 & 257 & -7 & 232 \\
\hline Australia \& New Zealand & 94 & 346 & 335 & 269 & -3 & 258 \\
\hline Rest of Europe & 62 & 240 & 212 & 287 & -12 & 241 \\
\hline Latin America \& Caribbean & 54 & 207 & 219 & 286 & 6 & 310 \\
\hline Rest of World & 17 & 66 & 65 & 277 & -1 & 272 \\
\hline Oceania & 8 & 31 & 29 & 261 & -5 & 242 \\
\hline
\end{tabular}

Note: The table shows by source country the value added flows embodied in German final goods exports to the US. Scale effect: VA growth going from initial to deep TTIP, but keeping the (German) sourcing structure (i.e. Leontief coefficients) as in initial situation. The scale effect corresponds to the export growth of Germany, but due to sectoral heterogeneity the scale effect can vary by source country. Sourcing effect: VA growth going from deep TTIP with initial sourcing structure to deep TTIP with new sourcing structure (i.e. counterfactual Leontief coefficients). It shows the effect of changes in the supply chains. Total effect: total VA growth going from initial to deep TTIP.

${ }^{a}$ Southern African Customs Union, ${ }^{b}$ European Free Trade Association, ${ }^{c}$ Middle East \& North Africa, ${ }^{d}$ Association of Southeast Asian Nations.

countries are in faster growing sectors. When allowing for the adjustment of the inputoutput coefficients along the global value chain, the US considerably increases its role for Germany as a source of value added. Its share in processed value added goes up from 2 to 9\%. Countries in the North American production network (like Canada or Mexico) also benefit from this. Germany sources more value added from these countries (because they trade intensively with the US). However, their shares still remain small. 
Summarizing, the transatlantic production network is strengthened with the TTIP. Germany relies more on US inputs to process its output. And German value added becomes more important in the absorption of US consumers directly (by final goods exports), and indirectly by exporting intermediates, in particular to the US and other EU countries, which then process the German value added for final consumption in the US.

\subsection{Effects on sectoral value added}

In this section, we investigate the effects of the TTIP on the production structure. All results stem from the base scenario, i.e. deep TTIP from IV regressions. Table 9 shows by region the share of agriculture, manufacturing and services in total value added. In both the EU and the US, services industries make up by far the largest part of total value added. $73 \%$ in the EU and $82 \%$ in the US. Manufacturing is still more important in the EU than in the US. In Germany, the share of manufacturing is $28.4 \%$ and higher than in most developed economies. Agricultural value added, on the other hand, plays a minor role. Our simulations predict that the TTIP leads to a slight reindustrialization in the EU. The share of manufacturing value added in total value added increases by 0.3 percentage points, on average. In Germany, it is even 0.4 percentage points, and starting from a higher initial value. On the other hand, both service industries and agriculture lose a small share in total value added.

Within the EU, however, this trend of reindustrialization is not universal. Figure 5 shows a kernel density estimate of the changes in the manufacturing (dark blue lines) and service industry (light blue lines) share. The distribution for the TTIP countries (solid line) of manufacturing peaks slightly above zero, but also reaches into the negative area. So while the shifts are not dramatic, some Central and Eastern European economies-like Bulgaria, the Czech Republic, Estonia, Poland and Slovenia-and also Spain and Luxembourg shift away from manufacturing. In Bulgaria, the agricultural share increases. In the other countries, service industries pick up. Still, in the big economic centers in 
Table 9: The effects of a TTIP on sectoral value added

\begin{tabular}{|c|c|c|c|c|c|c|}
\hline & (1) & $(2)$ & $(3)$ & $(4)$ & $(5)$ & (6) \\
\hline & \multicolumn{2}{|c|}{ Agriculture } & \multicolumn{2}{|c|}{ Manufacturing } & \multicolumn{2}{|c|}{ Services } \\
\hline & $\begin{array}{l}\text { Initial } \\
\text { share } \\
(\text { in } \%)\end{array}$ & $\begin{array}{c}\text { Counter- } \\
\text { factual } \\
\text { change } \\
\text { (in \%points) }\end{array}$ & $\begin{array}{l}\text { Initial } \\
\text { share } \\
(\text { in } \%)\end{array}$ & $\begin{array}{c}\text { Counter- } \\
\text { factual } \\
\text { change } \\
\text { (in \%points) }\end{array}$ & $\begin{array}{l}\text { Initial } \\
\text { share } \\
(\text { in } \%)\end{array}$ & $\begin{array}{c}\text { Counter- } \\
\text { factual } \\
\text { change } \\
\text { (in \%points) }\end{array}$ \\
\hline \multicolumn{7}{|l|}{ TTIP countries } \\
\hline EU27 & 2.3 & -0.1 & 24.6 & 0.3 & 73.1 & -0.2 \\
\hline Germany & 1.4 & -0.1 & 28.4 & 0.4 & 70.2 & -0.3 \\
\hline USA & 1.4 & 0.1 & 16.6 & -0.1 & 82.0 & -0.0 \\
\hline \multicolumn{7}{|l|}{ Non-TTIP regions } \\
\hline ASEAN & 10.6 & -0.0 & 36.7 & -0.2 & 52.7 & 0.3 \\
\hline Australia \& New Zealand & 4.0 & -0.0 & 19.8 & -0.1 & 76.1 & 0.1 \\
\hline Canada & 2.2 & -0.0 & 23.0 & -0.2 & 74.8 & 0.2 \\
\hline Central Asia & 9.3 & -0.0 & 28.9 & -0.1 & 61.8 & 0.1 \\
\hline China & 10.8 & -0.1 & 37.6 & -0.0 & 51.6 & 0.1 \\
\hline EFTA & 1.4 & -0.0 & 24.4 & -0.2 & 74.2 & 0.2 \\
\hline East Asia & 1.5 & 0.0 & 21.8 & -0.2 & 76.7 & 0.1 \\
\hline Eurasian Customs Union & 6.9 & -0.0 & 27.8 & -0.1 & 65.3 & 0.1 \\
\hline Latin America \& Caribbean & 8.3 & -0.1 & 20.6 & -0.1 & 71.1 & 0.2 \\
\hline MERCOSUR & 7.2 & -0.1 & 23.0 & -0.0 & 69.8 & 0.1 \\
\hline MENA & 8.0 & -0.0 & 39.3 & -0.1 & 52.6 & 0.2 \\
\hline Oceania & 5.8 & -0.1 & 25.7 & -0.3 & 68.5 & 0.4 \\
\hline Oil exporters & 0.9 & -0.0 & 62.1 & -0.2 & 37.0 & 0.2 \\
\hline Pacific Alliance & 5.1 & -0.0 & 29.1 & 0.0 & 65.8 & -0.0 \\
\hline Rest of Europe & 7.7 & -0.0 & 24.6 & -0.2 & 67.6 & 0.2 \\
\hline Rest of World & 11.7 & -0.1 & 14.2 & -0.3 & 74.1 & 0.4 \\
\hline South Asia & 17.3 & -0.0 & 19.5 & -0.1 & 63.1 & 0.2 \\
\hline $\mathrm{SACU}$ & 3.5 & -0.0 & 25.8 & -0.1 & 70.8 & 0.1 \\
\hline Sub-Saharan Africa & 26.2 & -0.1 & 33.4 & -0.0 & 40.4 & 0.1 \\
\hline Turkey & 7.6 & -0.1 & 27.2 & -0.1 & 65.2 & 0.2 \\
\hline
\end{tabular}

Note: The table shows the initial shares of agriculture, manufacturing and service industries in total value added in \% (odd columns), and the respective counterfactual change with deep TTIP in percentage points (even columns).

Europe - like Germany, Italy, the UK and also France - there is a shift towards manufacturing under the TTIP. In the US, on the other hand, the manufacturing share declines by 0.08 percentage points and also services industries lose some ground to the benefit of agriculture.

Table 9 also shows that in non-TTIP countries, the opposite trend occurs. The share of services in total value added tends to increase at the detriment of manufacturing. This pattern is also support by Figure 5. The distribution of the changes in manufacturing shares for non-TTIP countries (dashed, dark blue line) is mostly in the negative area. 
Figure 5: Changes in manufacturing and services shares with the TTIP

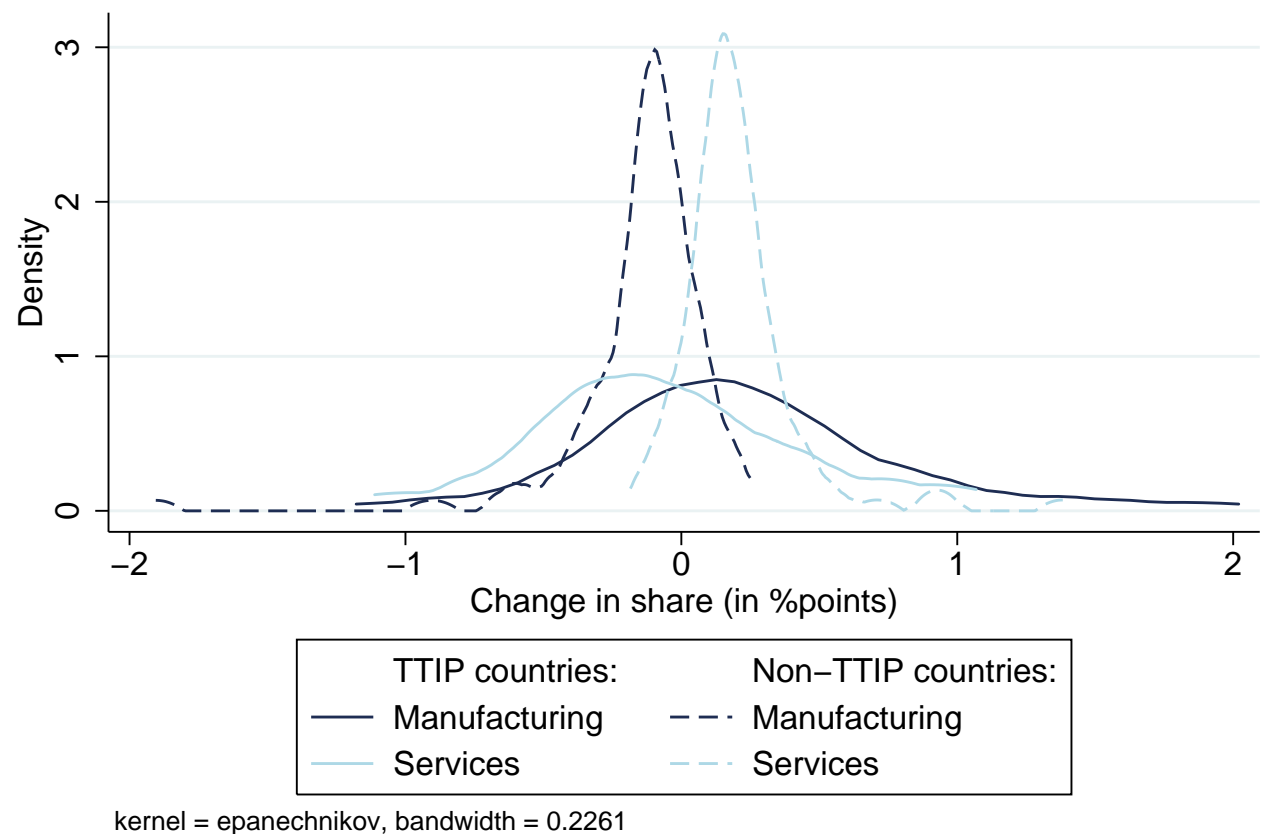

Note: The figure shows the density of changes of the share of manufacturing (dark blue line) and services (light blue line) value added (in percentage points) for the TTIP scenario of deep trade integration distinguished by the TTIP (solid line) and non-TTIP countries (dashed line). Malta for scaling reasons not in graph.

Next, we provide a detailed analysis of the sectoral changes in the biggest Atlantic economies, namely Germany and the USA. Figure 6 shows the changes in sectoral value added from the TTIP (red lines, right scale). As a reference, the figure shows the initial value added of all sectors with a value added share above $1 \%$ in descending order of their share in total value added (dark blue bars, left scale).

The effect of the TTIP on sectoral production values is very heterogenous. In Germany, the transport equipment sector experiences the largest growth in value added, $+17 \%$. Given that tariffs on transport equipment are still relatively high in the US and that German car manufacturing is an important economic sector (about 4\% of total German value added), this seems plausible. Sectors that provide services to the car manufacturing industry also grow. For example, Other Business Services have a value added growth of about $0.6 \%$, although from a larger base (the sector makes up about a quarter of total 
Figure 6: Sectoral value added: initial levels and TTIP-induced changes

(a) Germany

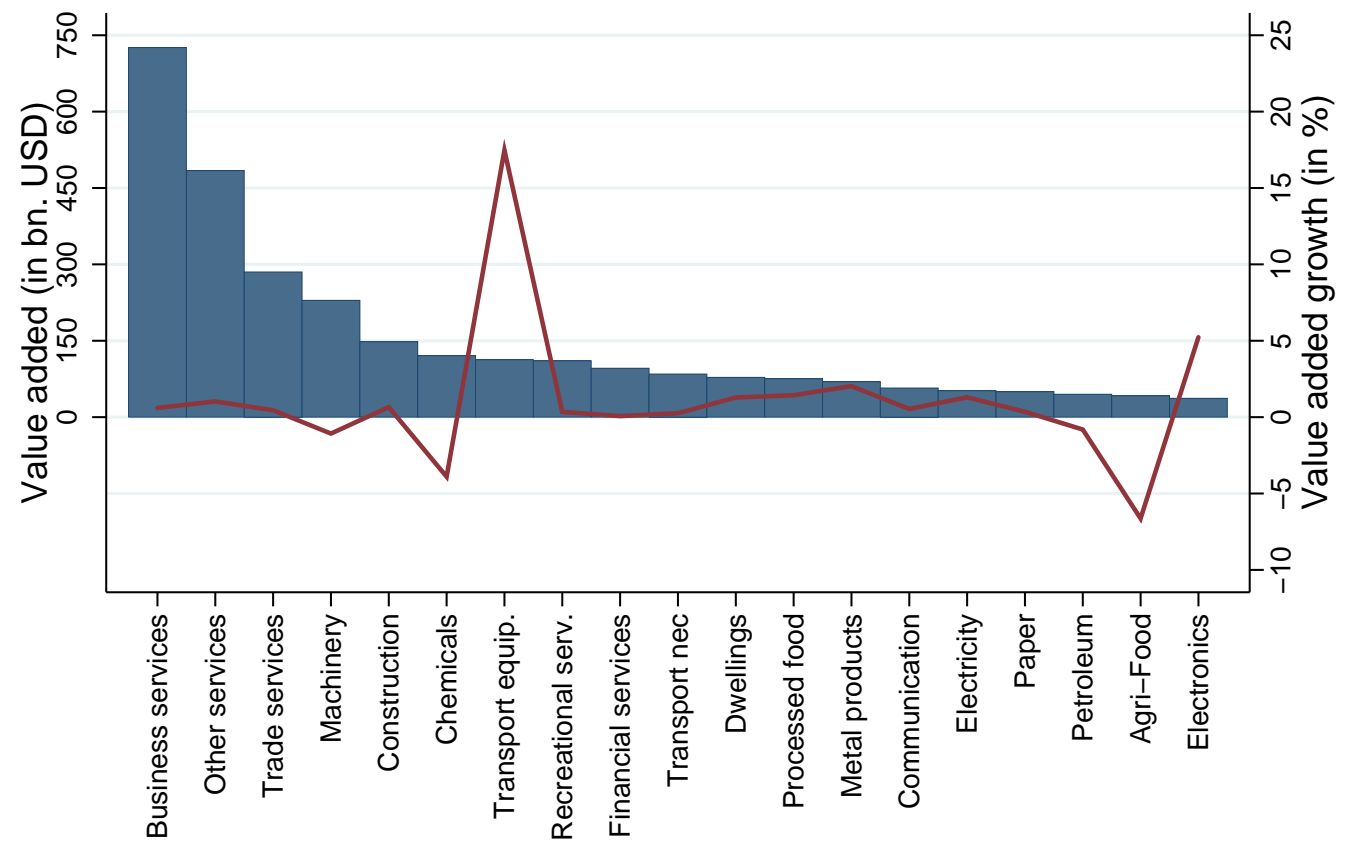

(b) United States

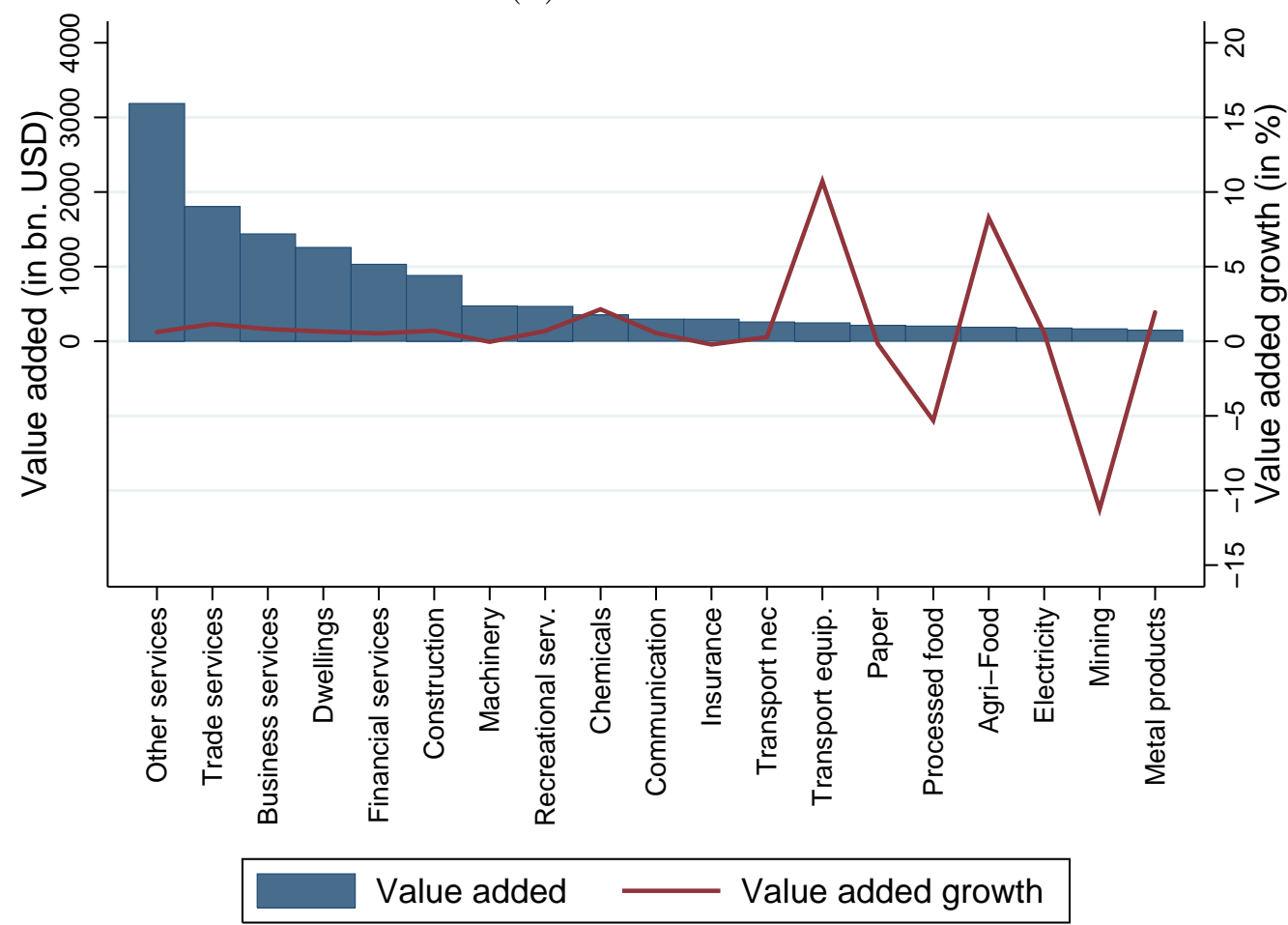

Note: The figure shows the changes in sectoral output (in \%) for the TTIP scenario of deep trade integration, for (a) Germany and (b) the USA. The figure only lists sectors with a value added share of above 1\%. Due to the Cobb-Douglas production structure, output changes are equivalent to value added changes. The sectors are listed on the vertical axis with their GTAP short description. An overview of the sectors is provided in Table A1 in the online appendix. 
value added in Germany). The chemical and machinery sector, on the other hand, shrink.

In the US, the most important sectors are service industries like Other, Trade, Business, and Financial Services and Construction. These sectors slightly grow with the TTIP. As in Germany, however, the transport equipment sector grows most, by about $10 \%$. The US can also increase its production of Agri-Food products. Interestingly the Processed Food sector shrinks.

The observed pattern suggests that comparative advantage plays a role for specialization under the TTIP. Germany specializes more in manufacturing, and especially so in the transport equipment sector. The US, on the other hand, presumably has a comparative advantage in chemicals and agriculture and increases its share of agriculture in total value added. A regression of the change in the (multilateral) revealed comparative advantage ${ }^{28}$ (RCA, in percentage points) on the initial RCA gives a positive coefficient of 0.047 , statistically significant at the $1 \%$ level. ${ }^{29}$ So the increase in the RCA is positively correlated with the initial revealed comparative advantage under the TTIP. This suggests that, with the TTIP, countries tend to specialize in sectors they have a comparative advantage in.

Figure 7 shows that in Germany, the transport equipment sector is the only sector with an initial revealed comparative advantage that can further increase its RCA. Other sectors, where Germany is relatively good at exporting, like "Chemicals" or "Machinery", lose some of their revealed comparative advantage. The upper left quadrant shows sectors, for which Germany so far had a revealed comparative disadvantage, and could increase its competitiveness. Examples are "Electronics", "Textiles" or "Leather". However, these sectors might indirectly benefit from increased transport equipment exports. So while there is some evidence, that Germany specializes in comparative advantage industries,

\footnotetext{
${ }^{28}$ The RCA of a country in a given sector is defined as the sector's share in the country's export in relation to the sector's share in world exports (see Balassa, 1965). An RCA larger than 1 reveals that, compared to the world, the country exports relatively much of the sector's goods, i.e. the country has a revealed comparative advantage. And vice versa for an RCA smaller than one.

${ }^{29}$ The result does not change when including sector dummies or looking at the subsample of sectors with an RCA larger than one.
} 
Figure 7: Changes in revealed comparative advantage

(a) Germany

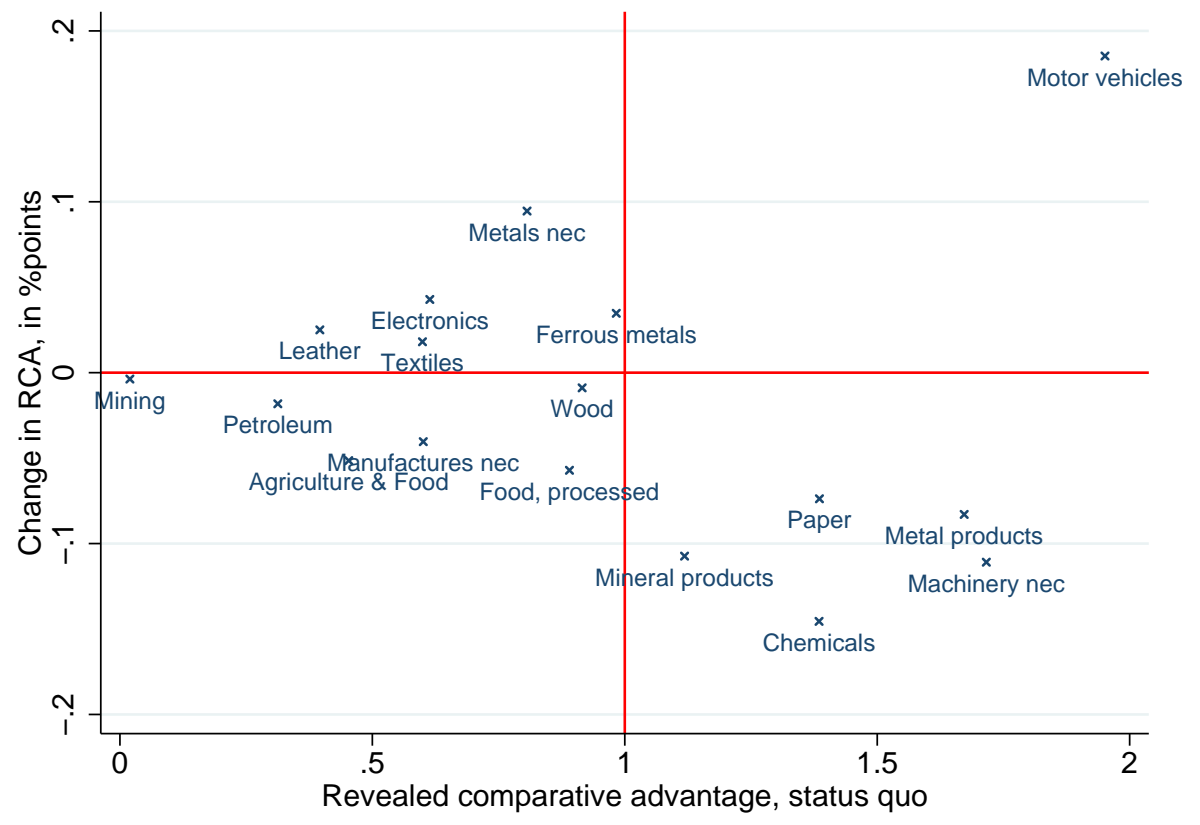

(b) United States

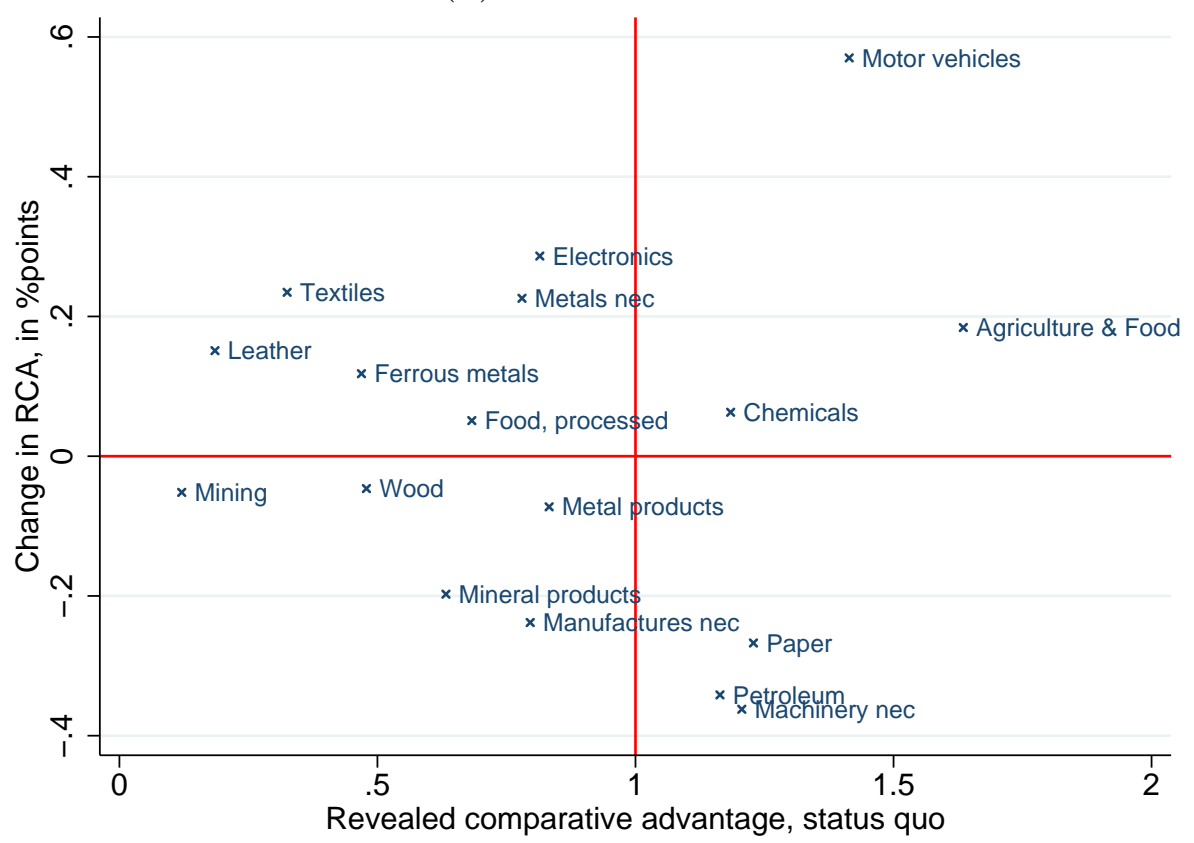

Note: The figure shows a scatter plot of the sectoral measure of revealed comparative advantage plotted against its change (in percentage points) from switching to the TTIP scenario with deep integration, for (a) Germany and (b) the United States. 
Table 10: Explaining sectoral value added change

\begin{tabular}{lcccccc}
\hline & $(1)$ & $(2)$ & $(3)$ & $(4)$ & $(5)$ & $(6)$ \\
& \multicolumn{5}{c}{$\ln (\widehat{V A})$} \\
\hline Ln price change & $0.143^{*}$ & $0.140^{*}$ & $0.135^{*}$ & 0.025 & $0.165^{* *}$ & 0.057 \\
& $(0.078)$ & $(0.078)$ & $(0.078)$ & $(0.091)$ & $(0.082)$ & $(0.093)$ \\
Ln productivity dispersion & $-0.123^{* * *}$ & $-0.121^{* * *}$ & $-0.122^{* * *}$ & & $-0.112^{* * *}$ & \\
& $(0.024)$ & $(0.024)$ & $(0.024)$ & & $(0.024)$ & \\
Ln value added cost share & $0.044^{* * *}$ & $0.060^{* * *}$ & $0.057^{* * *}$ & -0.024 & $0.059^{* * *}$ & -0.018 \\
& $(0.015)$ & $(0.016)$ & $(0.016)$ & $(0.022)$ & $(0.015)$ & $(0.023)$ \\
Ln initial VA share & 0.013 & $-0.039^{* *}$ & $-0.060^{* * *}$ & 0.012 & $-0.068^{* * *}$ & -0.020 \\
& $(0.016)$ & $(0.016)$ & $(0.017)$ & $(0.036)$ & $(0.017)$ & $(0.038)$ \\
Ln initial RCA & & $0.078^{* * *}$ & $0.089^{* * *}$ & $0.052^{* * *}$ & $0.079^{* * *}$ & $0.048^{* * *}$ \\
& & $(0.015)$ & $(0.016)$ & $(0.016)$ & $(0.017)$ & $(0.015)$ \\
Ln initial import penetration & & & $-0.048^{* * *}$ & $0.060^{* * *}$ & $-0.062^{* * *}$ & 0.026 \\
& & & $(0.014)$ & $(0.019)$ & $(0.013)$ & $(0.019)$ \\
\hline Sector FE & & & & YES & & YES \\
Country FE & 4,266 & 4,132 & 4,132 & 4,132 & 4,132 & 4,132 \\
\hline Observations & 0.050 & 0.053 & 0.055 & 0.140 & 0.110 & 0.187 \\
$\mathrm{R}^{2}$ & & & & & & \\
\hline
\end{tabular}

Note: The table shows standardized coefficients of estimates on pooled sectoral data of the log of $\widehat{V A}_{i}^{s}$. Standard errors (in parentheses) are heteroskedasticity-robust. *, ** and *** indicate statistical significance at the 10,5 and $1 \%$ level, respectively. The covariates are (all in logs): the sectoral productivity dispersion $\theta^{s}$, the sectoral value added intensity $\beta_{i}^{s}$, the initial share of the sectoral value added in a country's total value added (to measure the sector's importance) $\frac{V A_{i}^{s}}{V A_{i}}$, the initial revealed comparative advantage (RCA), the initial level of import penetration $1-\frac{I m p_{i i}}{\sum_{j} I m p_{j i}}$, and the initial export share $1-\frac{E x p_{i i}}{\sum_{j} E x p_{i j}}$.

there are many rules to the exception. I.e. there are many observations in the off-diagonal quadrants in Figure 7.

For the US, a similar picture emerges. The country increases its revealed comparative advantage in three of its six RCA industries, namely "Transport equipment", "Agriculture" and "Chemicals". It also gains ground in some revealed comparative disadvantage industries like "Electronics".

Next, we look into the determinants of sectoral value added changes. Table 10 shows standardized coefficients of pooled sectoral regressions of $\ln \left(\widehat{V A}_{i}^{s}\right)$ on different explanatory variables. ${ }^{30}$ Some regressions include sector and/or country dummies. Between 5 and $20 \%$

\footnotetext{
${ }^{30}$ From column (1) to (2), the number of observations drops by 32 because there is no trade in the sector 32 "Dwellings" and therefore, the RCA measure is not defined.
} 
of the variation in sectoral changes of value added can be explained with our regressions. Aside from country or sector dummies, a sector's productivity dispersion has the highest explanatory power for sectoral changes in value added. A one standard deviation increase of $\ln \theta$ leads to a reduction of $\ln V A$ of about 0.12 of a standard deviation. In highly dispersed sectors, i.e. sectors with a high $\theta$, output reacts less to our trade policy shock. ${ }^{31}$ In more dispersed sectors sectoral varieties are less substitutable. Consequently, trade cost changes have a smaller impact on sectoral trade and sectoral output. The second most important explanatory variable is revealed comparative advantage. Sectors with a higher initial revealed comparative advantage experience stronger growth in sectoral value added. So with the TTIP, countries tend to specialize in sectors in which they have a comparative advantage. Higher import penetration, on the other hand, deters sectoral growth. Labor-intensive sectors have higher value added growth. A sector's initial share in total value added is negatively related to sectoral growth. However, the coefficient is not statistically different from zero in most cases. So there is some weak evidence, that countries do not necessarily grow in important sectors. An alternative explanation for this finding is that growth rates are smaller in large sectors because they start from a higher initial output level.

\subsection{Welfare effects of the TTIP}

In our baseline scenario, we assume that the TTIP will be a deep PTA. Given that most new PTAs between developed countries are PTAs of the new generation and go way beyond a mere reduction or elimination of bilateral tariffs, this choice seems reasonable. Moreover, the negotiating mandate that EU member states have given to the EU Commission makes the high level of ambition for the agreement very clear. Nonetheless, we contrast the so obtained results with alternative TTIP scenarios in the next section. In a

\footnotetext{
${ }^{31}$ Note that, since productivity is sector-specific but does not vary across countries, we cannot identify the coefficient on sectoral productivity dispersion once we include sector fixed effects.
} 
first set of scenarios, the depth of trade liberalization is adjusted. In a second set of scenarios, we investigate the effects of regulatory spillovers. Last, we investigate the welfare effects when the TTIP is accompanied by a round of multilateral tariff reductions under the WTO.

A regional breakdown of the effect of a deep TTIP on countries' real incomes is provided in column 1 of Table $11 .{ }^{32}$ With the TTIP, the US real income increases by $2.7 \%$. In the EU, real income rises slightly less on average, by $2.1 \%{ }^{33}$ The effect is dispersed within the EU. While the core EU countries like the UK, Germany and France benefit more than the average EU country, in particular the Southern European countries like Spain, Italy and Greece and most Central and Eastern European countries (CEEC) only realize welfare gains of around $1 \%$. I.e. the TTIP leads to a divergence in real incomes within the EU. Hence, the finding in Felbermayr et al. (2014) does not seem to be robust to allowing for multiple sectors and input-output links.

Most non-TTIP regions also slightly benefit from the TTIP. Regions close to the EU, like the Rest of Europe, Central Asia, the EFTA and MENA countries as well as Turkey stand to gain most. These regions are deeply embedded in the European production network and therefore benefit from an increased demand for (final and intermediate) goods in the EU. For Canada, the increase in real income is small (about 0.1\%). Countries in the Asian production network, on the other hand, tend to lose from the TTIP. Our simulations predict a reduction of real income of $0.23 \%$ for China, $0.20 \%$ for ASEAN countries and $0.13 \%$ for Japan and South Korea (East Asia). Since the TTIP leads to losses in the big economies in East and Southeast Asia it is, on average, marginally detrimental for non-TTIP countries. Given that these losses will be realized in the medium run (over 10-12 years), the annualized malus on growth is relatively low compared to the annual growth rates in most developing countries. So, taken together, TTIP is beneficial for the

\footnotetext{
${ }^{32}$ The online appendix presents effects for all 134 countries/regions.

${ }^{33}$ The EU countries' real income changes are weighted with GDP shares to calculate the average.
} 
Table 11: Simulated changes of real income due to the TTIP

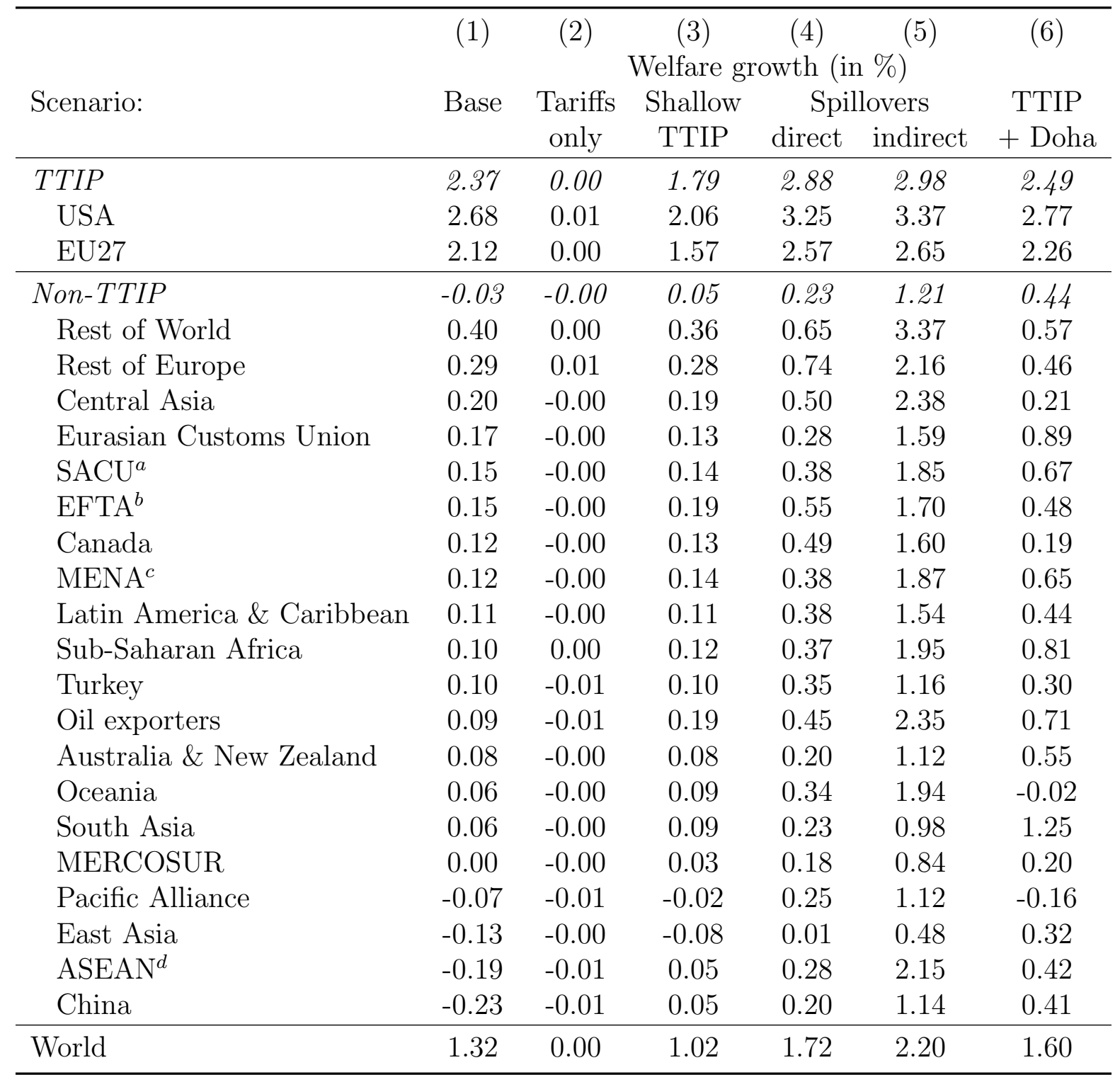

Note: The regional real income change is a GDP-weighted sum of the respective countries' real income changes. An overview of the classification of countries into regions is provided in the online appendix. Base: deep TTIP scenario. Direct spillovers: deep TTIP scenario plus trade cost reduction for non-TTIP countries' exports to the EU and US by $20 \%$ of the trade cost reduction within TTIP. Indirect spillovers: Direct spillover scenario plus trade cost reduction between third countries and TTIP countries' exports to third countries of $10 \%$ of the trade cost reductions within TTIP. TTIP+Doha: deep TTIP scenario plus elimination of all tariffs between WTO member states.

${ }^{a}$ Southern African Customs Union, ${ }^{b}$ European Free Trade Association, ${ }^{c}$ Middle East \& North Africa,

${ }^{d}$ Association of Southeast Asian Nations.

world. It leads to an increase in world real income of $1.3 \%$, on average. 


\subsection{Welfare effects of TTIP-Alternative scenarios}

To get a better sense of the magnitude of the effects, we now vary the intensity of trade cost reductions the TTIP may provide. First, the TTIP may only lead to the elimination of tariffs. Second, it may only achieve a shallow instead of a deep reduction of NTMs. The results are presented in columns 2 and 3 of Table 11. The tariffs between the EU and the US are already relatively low. An elimination of the bilateral tariffs therefore does not lead to any measurable gains from trade. If the negotiated TTIP agreement is shallow the gains from trade fall slightly short of the ones in the baseline scenario. However, the expected welfare gains are still sizable, $2.1 \%$ higher real income for the US and $1.6 \%$ for the EU, on average. The negative consequences for third countries are also less severe. Non-TTIP countries slightly raise their real income by $0.05 \%$, on average.

Next, we discuss two scenarios where the TTIP also leads to spillovers. The rationale behind these scenarios is that the TTIP might lead to unified transatlantic product standards due to regulatory cooperation, or the mutual recognition of standards (see, e.g., the discussions in WTO, 2012). This potentially leads to trade cost reductions for firms who export to the US and the EU (direct spillovers) because they only have to abide by one standard for exports to both regions. ${ }^{34}$ If the TTIP shapes global product standards, the trade cost reductions may even spill over to trade between third countries (indirect spillovers). ${ }^{35}$ Whether spillovers are likely is not clear. So far, there is little empirical evidence pointing toward positive third-country effects of mutual recognition agreements or standard harmonization (see Chen and Mattoo, 2008; Baller, 2007). And if so, it seems to be crucial that the countries can adopt the (high) standards. So especially developing countries are hurt by standard harmonization. ${ }^{36}$ Therefore, we use rather ad-hoc assump-

\footnotetext{
${ }^{34}$ For the simulation, we work with a trade cost reduction of $20 \%$ of the full PTA effect that arises between the TTIP countries.

${ }^{35}$ We assume that the indirect spillovers amount to $10 \%$ of the trade cost reduction between the TTIP countries.

${ }^{36}$ Cadot et al. (2012) show that regulatory cooperation in North-South PTAs deters South-South trade.
} 
Figure 8: Density of changes in real income with the TTIP

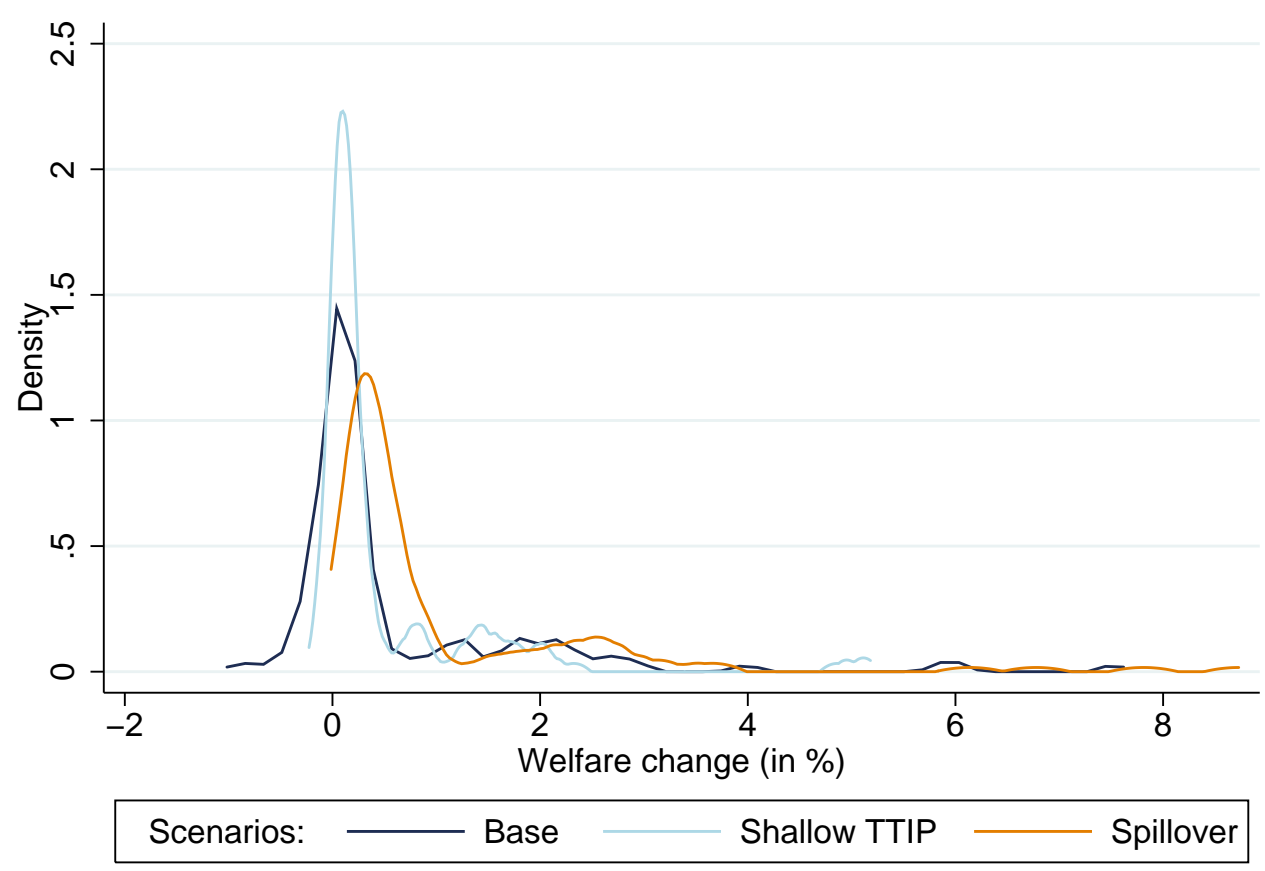

kernel $=$ epanechnikov, bandwidth $=0.1091$

Note: The figure shows the density of changes in real income (in \%) for different TTIP scenarios.

tions as to how spillovers affect trade costs. Nevertheless, it is instructive to simulate spillover scenarios. In terms of policy implications, they provide interesting insights, as we will discuss later.

Direct spillovers from unified standards bring additional welfare gains for the TTIP regions (see column 3 of Table 11). For the EU and the US, the real income increase is by 0.4 and 0.6 percentage points, respectively, higher than in the baseline. But also nonTTIP countries benefit from 0.3 percentage points higher growth. If the gains from global standards also indirectly spill over to third country trade, non-TTIP countries will also largely benefit from the TTIP, see column 4 of Table 11. The average real income increase is $1.2 \%$. The additional effects for the TTIP countries are small and in the magnitude of 0.1 percentage points more growth.

Figure 8 visualizes the welfare effects of the TTIP across different scenarios. It shows 
the density of the distribution of real income changes. The dark blue line represents the baseline scenario. It has two peaks, one around zero which captures the real income effects for non-TTIP countries and a second peak to the right (around 2\%) which traces the effects on TTIP countries. With a shallow TTIP (light blue line), the two peaks slightly move together. The effects for both TTIP and non-TTIP countries are dampened. With direct spillovers (orange line), the distribution moves to the right. All countries tend to be better off and there are virtually no negative real income effects. What is more, the shift of the first peak is relatively larger. So non-TTIP countries benefit more from spillovers. Nevertheless, the TTIP countries would also benefit from unified product standards.

These findings imply that a TTIP with spillovers is a win-win situation for the TTIP insiders as well as outsiders. Consequently, an inclusive TTIP that, e.g., interprets rules of origins fairly generously can increase good-will in third countries. This in turn may stimulate multilateral trade liberalization. But of course it all hinges on the (implicit) assumption, that developing countries can meet the set standards.

Last, we simulate the effects of a TTIP in a world where a further wave of multilateral tariff liberalizations could be achieved in the Doha round. More specifically, the simulation is based on eliminating all tariffs between WTO member states. If the TTIP is inclusive, i.e. the agreement is such that trade diversion in third countries is limited as best as possible, it may help to stimulate another round of multilateral tariff liberalization. Indeed, the international economics literature discusses whether PTAs constitute a "building block" or "stumbling block" for free trade (see Bhagwati, 1991, for an introduction of the concepts). In the TTIP + Doha scenario, we find that real income rises for all regions except Oceania and the Pacific Alliance. The additional effects for the TTIP countries are relatively small. However, for some regions like South Asia, Sub-Saharan Africa or the Eurasian Customs Union a sizeable positive impulse for the economy can be expected. These regions are still characterized by considerable MFN tariffs.

Summarizing, only a deep TTIP will reap the full gains from trade for TTIP countries. 
They are in the order of magnitude of 2 to $3 \%$ real income growth. If the TTIP is accompanied by spillover effects, adverse effects for other regions of the world can be prevented and instead turned into small welfare increases as well. This is also beneficial for TTIP countries. Especially from the point of view of developing countries, it is highly desirable to accompany the TTIP by another round of multilateral trade liberalization. This will raise real income in all regions as well.

\section{Conclusion}

A number of systemically relevant preferential trade agreements (PTAs) are under negotiation. The largest of these mega-regionals is the proposed Transatlantic Trade and Investment Partnership (TTIP). In this paper, we have extended the recent multi-country, multi-industry Ricardian trade model by Caliendo and Parro (2014) so that it features PTAs, the costs of non-tariff measures (NTMs), and also covers services trade. We use the gravity equation generated by the model to estimate the Frechet parameters governing the world-wide dispersion of productivities within sectors and the trade cost reductions achieved by existing shallow and deep PTAs. We simulate the model to quantify the trade and welfare effects that a deep TTIP could have. However, the model could also be applied to PTAs, or to trade policy initiatives at the multilateral level.

The main assumption of our quantitative experiment is that the TTIP eliminates tariffs between EU countries and the US and lowers the costs of NTMs by the amount empirically identified for existing bilateral agreements. We find that the potential effects of the TTIP are quite substantial: per capita income could go up by between $2 \%$ and $3 \%$ in the EU and US, respectively. Average per capita income in the world would also increase, but some non-TTIP countries, mostly in East and Southeast Asia would lose. These effects are driven by a strong amount of trade creation within the TTIP. The framework is ideally suited to study the effects of the agreement on the structure of regional and 
global production networks. Our results suggest that the TTIP would strengthen trade in parts and components across the Atlantic, thereby creating a transatlantic production network.

Our framework is close to recent work surveyed by Costinot and Rodríguez-Clare (2014). New quantitative trade theory uses parsimonious trade models and shows how they can be brought to the data by structurally estimating the key parameters. For the time being, these frameworks are only starting to be applied to the analysis of real trade policy initiatives; most existing work still uses more traditional large-scale computable general equilibrium (CGE) models. While the availability of industry-level trade and output data, the information on existing PTAs, and the state-of-the-art of econometric tools has much improved over the last years, there is particular need for further work in at least four areas: First, the unbiased econometric estimation of structural parameters requires quasi-experimental variation and appropriate methods. This remains an important area for future work. Second, top-down approaches to NTMs, as used in this paper, differ from bottom-up assessments based on Francois et al. (2009). Understanding this discrepancy is key if one wants to narrow the interval of welfare predictions found in studies with different approaches to NTMs. Third, both traditional CGE models as well as the frameworks surveyed by Costinot and Rodríguez-Clare (2014) neglect foreign direct investment. This is particularly important in the transatlantic context. Fourth, estimates presented in this paper may underestimate the true effects as they do not account for effects of trade liberalization on the incentives to develop new products or engineer new processes. A tractable dynamic framework would be highly welcome. 


\section{References}

Aichele, Rahel and Inga Heiland, "Where is the Value Added? Trade Liberalization and Production Networks," Technical Report, mimeo 2014.

Alvarez, Fernando and Robert Jr. Lucas, "General equilibrium analysis of the EatonKortum model of international trade," Journal of Monetary Economics, September 2007, 54 (6), 1726-1768.

Anderson, James E., Mario Larch, and Yoto V. Yotov, "On the Effects of the Transatlantic Trade and Investment Partnership on Trade and Capital Accumulation," Technical Report, Boston University 2014.

Balassa, Bela, "Trade Liberalization and Revealed Comparative Advantage," The Manchester School, 1965, 33 (2), 99-123.

Baldwin, Richard, "21st Century Regionalism: Filling the gap between 21st century trade and 20th century trade rules," CEPR Policy Insight No. 56, Center for Economic Policy Research May 2011.

- and Dany Jaimovich, "Are Free Trade Agreements contagious?," Journal of International Economics, 2012, 88 (1), 1 - 16.

Baller, Silja, Trade Effects Of Regional Standards Liberalization : A Heterogeneous Firms Approach, The World Bank, 2007.

Bhagwati, Jagdish N., The World Trading System at Risk, Princeton University Press, 1991.

Cadot, Olivier, Anne-Célia Disdier, and Lionel Fontagné, "North-South Standards Harmonization and International Trade," CEPR Discussion Papers 8767, Centre for Economic Policy Research January 2012. 
Caliendo, Lorenzo and Fernando Parro, "Estimates of the Trade and Welfare Effects of NAFTA," Review of Economic Studies, 2014, forthcoming.

Chen, Maggie Xiaoyang and Aaditya Mattoo, "Regionalism in standards: good or bad for trade?," Canadian Journal of Economics, August 2008, 41 (3), 838-863.

Cipollina, Maria and Luca Salvatici, "Reciprocal Trade Agreements in Gravity Models: A Meta-Analysis," Review of International Economics, February 2010, 18 (1), 63-80.

Costinot, Arnaud and Andrés Rodríguez-Clare, "Trade Theory with Numbers: Quantifying the Consequences of Globalization," in Gita Gopinath, Elhanan Helpman, and Kenneth Rogoff, eds., Handbook of International Economics, Vol. 4 2014, chapter 4, pp. 197-261.

Dekle, Robert, Jonathan Eaton, and Samuel Kortum, "Global Rebalancing with Gravity: Measuring the Burden of Adjustment," IMF Staff Papers, July 2008, 55 (3), 511-540.

Dür, Andreas, Leonardo Baccini, and Manfred Elsig, "The Design of International Trade Agreements: Introducing a New Database," Review of International Organizations, 2014, 9 (3), 353-375.

Eaton, Jonathan and Samuel Kortum, "Technology, Geography, and Trade," Econometrica, September 2002, 70 (5), 1741-1779.

Egger, Hartmut, Peter Egger, and David Greenaway, "The trade structure effects of endogenous regional trade agreements," Journal of International Economics, 2008, 74 (2), $278-298$.

Egger, Peter, Joseph Francois, Miriam Manchin, and Douglas Nelson, "Non- Tariff Barriers, Integration, and the Trans-Atlantic Economy," Technical Report, paper prepared for the 60th Panel Meeting of Economic Policy, October 2014, Rom 2014. 
_, Mario Larch, and Kevin E Staub, "Trade Preferences and Bilateral Trade in Goods and Services: A Structural Approach," CEPR Discussion Papers 9051, C.E.P.R. Discussion Papers July 2012.

_ , _, Kevin E. Staub, and Rainer Winkelmann, "The Trade Effects of Endogenous Preferential Trade Agreements," American Economic Journal: Economic Policy, August 2011, $3(3), 113-43$.

Felbermayr, Gabriel, Benedikt Heid, and Sybille Lehwald, "Transatlantic Free Trade: Winners, Losers, and Necessary Accompanying Measures," Law and Business Review of the Americas, 2013, 19 (4), 445-484.

_, _, Mario Larch, and Erdal Yalcin, "Macroeconomic potentials of transatlantic free trade: A high resolution perspective for Europe and the world," Technical Report, paper prepared for the 60th Panel Meeting of Economic Policy, October 20142014.

Fontagné, Lionel, Julien Gourdon, and Sébastian Jean, "Transatlantic Trade: Whither Partnership, Which Economic Consequences?," CEPII Policy Brief No. 2013-01, CEPII September 2013.

Francois, Joseph, Hans van Meijl, and Frank van Tongeren, "Trade liberalization in the Doha Development Round," Economic Policy, April 2005, 20 (42), 349-391.

_, Koen Berden, Saara Tamminen, Martin Thelle, and Paul Wymenga, "NonTariff Measures in EU-US Trade and Investment - An Economic Analysis," Technical Report 2009. Study commissioned by the European Commission, DG Trade, ECORYS Netherland BV.

_, Miriam Manchin, Hanna Norberg, Olga Pindyuk, and Patrick Tomberger, "Reducing Transatlantic Barriers to Trade and Investment. An Economic Assessment," Technical Report, Centre for Economic Policy Research 2013. 
Head, Keith and Thierry Mayer, "Gravity Equations: Workhorse,Toolkit, and Cookbook," in G. Gopinath, E. Helpman, and K. Rogoff, eds., Handbook of International Economics, Vol. 4 2014, chapter 3, pp. 131-195.

Hertel, T.W., ed., Global Trade Analysis: Modeling and Applications, Cambridge University Press, 1997.

Johnson, Robert C. and Guillermo Noguera, "Accounting for intermediates: Production sharing and trade in value added," Journal of International Economics, March 2012, $86(2), 224-236$.

Koopman, Robert, Zhi Wang, and Shang-Jin Wei, "Tracing Value-added and Double Counting in Gross Exports," American Economic Review, 2014, 104 (2), 459-494.

Krugman, Paul, "Scale Economies, Product Differentiation, and the Pattern of Trade," The American Economic Review, 1980, 70 (5), 950-959.

Martin, Philippe, Thierry Mayer, and Mathias Thoenig, "The Geography of Conflicts and Regional Trade Agreements," American Economic Journal: Macroeconomics, October 2012, 4 (4), 1-35.

Wang, Zhi, Shang-Jin Wei, and Kunfu Zhu, "Quantifying International Production Sharing at the Bilateral and Sector Levels," NBER Working Paper No. 19677, National Bureau of Economic Research November 2013.

WTO, World Trade Report 2012 - Trade and public policies: A closer look at non-tariff measures in the 21st century, World Trade Organization, 2012. 
Online Appendix to

\title{
Going Deep: The Trade and Welfare Effects of TTIP
}

\author{
CESifo Working Paper No. 5150, 2014
}

Rahel Aichele*, Gabriel Felbermayr ${ }^{\dagger}$ and Inga Heiland ${ }^{\ddagger}$

*ifo Institute-Leibniz Institute for Economic Research at the University of Munich, Poschingerstr. 5, 81679 Munich, Germany and CESifo.

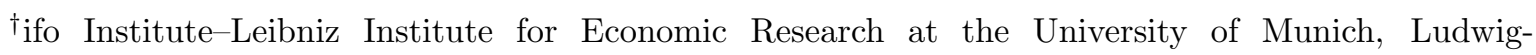
Maximilians-University Munich, CESifo, and GEP.

${ }^{\ddagger}$ ifo Institute-Leibniz Institute for Economic Research at the University of Munich. 
Table A1: Country-specific welfare results, various TTIP scenarios

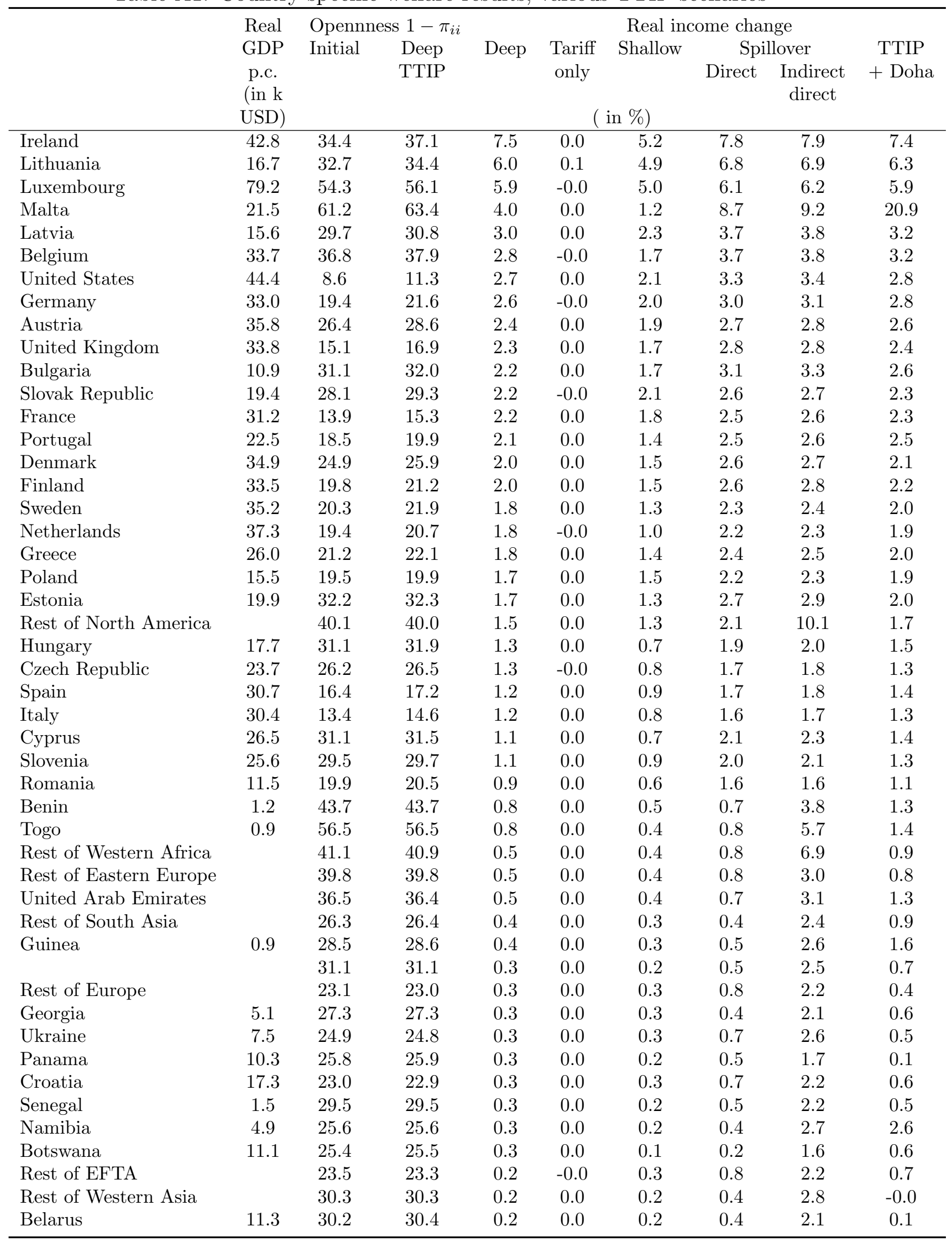


Table A1: Country-specific welfare results, various TTIP scenarios

\begin{tabular}{|c|c|c|c|c|c|c|c|c|c|}
\hline & \multirow{3}{*}{$\begin{array}{c}\text { Real } \\
\text { GDP } \\
\text { p.c. } \\
\text { (in k } \\
\text { USD) }\end{array}$} & \multicolumn{2}{|c|}{ Opennness $1-\pi_{i i}$} & \multicolumn{6}{|c|}{ Real income change } \\
\hline & & \multirow[t]{2}{*}{ Initial } & \multirow{2}{*}{$\begin{array}{l}\text { Deep } \\
\text { TTIP }\end{array}$} & \multirow[t]{2}{*}{ Deep } & \multirow{2}{*}{$\begin{array}{c}\text { Tariff } \\
\text { only }\end{array}$} & \multirow[t]{2}{*}{ Shallow } & \multicolumn{2}{|c|}{ Spillover } & \multirow{2}{*}{$\begin{array}{c}\text { TTIP } \\
+ \text { Doha }\end{array}$} \\
\hline & & & & & & & Direct & $\begin{array}{c}\text { Indirect } \\
\text { direct }\end{array}$ & \\
\hline Rest of Central America & & 29.4 & 29.4 & 0.2 & -0.0 & 0.3 & 1.3 & 3.9 & 12.9 \\
\hline Morocco & 3.2 & 20.4 & 20.3 & 0.2 & 0.0 & 0.2 & 0.8 & 2.6 & 1.5 \\
\hline Mauritius & 9.4 & 38.6 & 38.5 & 0.2 & 0.0 & 0.3 & 0.9 & 2.7 & 1.1 \\
\hline Ghana & 1.8 & 24.7 & 24.6 & 0.2 & 0.0 & 0.1 & 0.4 & 2.0 & 0.7 \\
\hline Qatar & 107.8 & 22.0 & 21.9 & 0.2 & -0.0 & 0.3 & 0.6 & 2.1 & 0.6 \\
\hline Norway & 50.0 & 17.9 & 17.8 & 0.2 & 0.0 & 0.2 & 0.5 & 1.6 & 0.5 \\
\hline Kenya & 1.3 & 18.5 & 18.4 & 0.2 & 0.0 & 0.2 & 0.5 & 2.1 & 1.1 \\
\hline Tunisia & 6.4 & 29.6 & 29.5 & 0.2 & 0.0 & 0.2 & 1.1 & 3.2 & 1.2 \\
\hline Ethiopia & 0.6 & 18.4 & 18.4 & 0.2 & 0.0 & 0.1 & 0.3 & 1.3 & 0.6 \\
\hline Russia & 16.4 & 12.8 & 12.8 & 0.2 & -0.0 & 0.1 & 0.3 & 1.6 & 1.0 \\
\hline Venezuela & 10.1 & 12.6 & 12.7 & 0.2 & 0.0 & 0.1 & 0.3 & 1.6 & 0.5 \\
\hline Kyrgyzstan & 2.2 & 29.9 & 29.8 & 0.2 & 0.0 & 0.1 & 0.2 & 1.8 & 0.5 \\
\hline Hong Kong & 37.0 & 26.5 & 26.5 & 0.2 & 0.0 & 0.1 & 0.4 & 2.5 & 0.6 \\
\hline South Africa & 7.7 & 14.3 & 14.2 & 0.2 & -0.0 & 0.1 & 0.4 & 1.8 & 0.5 \\
\hline Egypt & 4.3 & 19.7 & 19.7 & 0.2 & -0.0 & 0.1 & 0.4 & 1.9 & 3.9 \\
\hline Albania & 6.1 & 28.1 & 28.1 & 0.1 & 0.0 & 0.2 & 0.5 & 1.7 & 0.1 \\
\hline Caribbean & & 16.3 & 16.2 & 0.1 & -0.0 & 0.1 & 0.3 & 1.4 & 0.4 \\
\hline Armenia & 5.4 & 19.9 & 19.8 & 0.1 & 0.0 & 0.1 & 0.2 & 1.0 & 0.6 \\
\hline Paraguay & 3.8 & 22.9 & 22.9 & 0.1 & -0.0 & 0.0 & 0.7 & 2.8 & 1.6 \\
\hline Tanzania & 1.0 & 23.1 & 23.1 & 0.1 & 0.0 & 0.1 & 0.4 & 1.7 & 1.5 \\
\hline Bahrain & 29.7 & 30.6 & 30.5 & 0.1 & -0.0 & 0.2 & 0.4 & 2.8 & 0.6 \\
\hline Nepal & 1.0 & 17.1 & 17.1 & 0.1 & 0.0 & 0.1 & 0.1 & 1.1 & 1.5 \\
\hline Canada & 35.7 & 16.5 & 15.8 & 0.1 & -0.0 & 0.1 & 0.5 & 1.6 & 0.2 \\
\hline Israel & 24.4 & 22.5 & 22.3 & 0.1 & 0.0 & 0.2 & 0.4 & 1.6 & 0.4 \\
\hline Rwanda & 1.0 & 18.6 & 18.7 & 0.1 & 0.0 & 0.1 & 0.2 & 1.2 & 0.8 \\
\hline Laos & 2.1 & 21.6 & 21.6 & 0.1 & 0.0 & 0.1 & 0.2 & 2.4 & 0.3 \\
\hline Rest of North Africa & & 16.4 & 16.4 & 0.1 & -0.0 & 0.1 & 0.3 & 1.6 & -0.2 \\
\hline Kazakhstan & 11.8 & 17.8 & 17.8 & 0.1 & -0.0 & 0.1 & 0.3 & 1.8 & 0.2 \\
\hline Nigeria & 1.9 & 25.0 & 25.0 & 0.1 & 0.0 & 0.1 & 0.2 & 1.4 & 0.5 \\
\hline Madagascar & 0.8 & 18.1 & 17.9 & 0.1 & 0.0 & 0.1 & 0.6 & 1.9 & -0.2 \\
\hline Turkey & 12.7 & 15.6 & 15.5 & 0.1 & -0.0 & 0.1 & 0.4 & 1.2 & 0.3 \\
\hline Switzerland & 42.4 & 25.1 & 24.8 & 0.1 & -0.0 & 0.2 & 0.6 & 1.8 & 0.5 \\
\hline Cameroon & 1.8 & 12.6 & 12.5 & 0.1 & 0.0 & 0.1 & 0.4 & 1.3 & 0.4 \\
\hline Burkina Faso & 0.9 & 17.6 & 17.7 & 0.1 & 0.0 & 0.1 & 0.2 & 1.2 & 0.5 \\
\hline Colombia & 7.3 & 10.7 & 10.7 & 0.1 & -0.0 & 0.1 & 0.2 & 1.1 & 0.0 \\
\hline Honduras & 2.9 & 29.7 & 29.1 & 0.1 & -0.0 & 0.1 & 0.8 & 2.5 & -0.0 \\
\hline Rest of Eastern Africa & & 15.0 & 14.9 & 0.1 & 0.0 & 0.1 & 0.2 & 1.7 & 0.5 \\
\hline Central Africa & & 20.4 & 20.3 & 0.1 & 0.0 & 0.2 & 0.4 & 1.7 & 1.3 \\
\hline Australia & 36.5 & 10.6 & 10.6 & 0.1 & -0.0 & 0.1 & 0.2 & 1.1 & 0.5 \\
\hline El Salvador & 1.1 & 22.3 & 21.9 & 0.1 & -0.0 & 0.2 & 0.4 & 1.8 & 0.3 \\
\hline Uganda & 1.1 & 17.2 & 17.2 & 0.1 & 0.0 & 0.0 & 0.2 & 1.3 & 0.7 \\
\hline New Zealand & 27.2 & 12.7 & 12.6 & 0.1 & -0.0 & 0.1 & 0.3 & 1.4 & 0.8 \\
\hline India & 2.8 & 13.1 & 13.1 & 0.1 & -0.0 & 0.1 & 0.2 & 0.9 & 1.5 \\
\hline Pakistan & 2.3 & 15.5 & 15.3 & 0.1 & -0.0 & 0.1 & 0.2 & 1.2 & 0.4 \\
\hline Rest of Oceania & & 20.6 & 20.4 & 0.1 & -0.0 & 0.1 & 0.3 & 1.9 & -0.0 \\
\hline Malawi & 0.7 & 20.6 & 20.6 & 0.1 & 0.0 & 0.1 & 0.4 & 2.3 & 7.3 \\
\hline Rest of the World & & 14.6 & 14.3 & 0.1 & 0.0 & 0.1 & 0.3 & 1.2 & 0.0 \\
\hline Azerbaijan & 7.7 & 25.5 & 25.5 & 0.0 & 0.0 & 0.1 & 0.2 & 1.7 & -0.4 \\
\hline
\end{tabular}


Table A1: Country-specific welfare results, various TTIP scenarios

\begin{tabular}{|c|c|c|c|c|c|c|c|c|c|}
\hline & \multirow{3}{*}{$\begin{array}{c}\text { Real } \\
\text { GDP } \\
\text { p.c. } \\
\text { (in k } \\
\text { USD) }\end{array}$} & \multicolumn{2}{|c|}{ Opennness $1-\pi_{i i}$} & \multirow{3}{*}{ Deep } & \multirow{3}{*}{\multicolumn{2}{|c|}{$\begin{array}{cl} & \text { Real ince } \\
\text { Tariff } & \text { Shallow } \\
\text { only } & \end{array}$}} & me chan & & \multirow{3}{*}{$\begin{array}{c}\text { TTIP } \\
+ \text { Doha }\end{array}$} \\
\hline & & \multirow{2}{*}{ Initial } & \multirow{2}{*}{$\begin{array}{l}\text { Deep } \\
\text { TTIP }\end{array}$} & & & & Spil & ver & \\
\hline & & & & & & & Direct & $\begin{array}{c}\text { In- } \\
\text { direct }\end{array}$ & \\
\hline Bolivia & 3.6 & 15.7 & 15.7 & 0.0 & 0.0 & 0.0 & 0.2 & 1.0 & 0.4 \\
\hline Guatemala & 3.9 & 20.1 & 20.0 & 0.0 & -0.0 & 0.1 & 0.4 & 1.7 & -0.1 \\
\hline Zimbabwe & 3.7 & 36.6 & 36.5 & 0.0 & 0.0 & 0.1 & 0.4 & 3.6 & 5.3 \\
\hline Ecuador & 6.2 & 17.1 & 17.2 & 0.0 & 0.0 & 0.0 & 0.4 & 1.4 & 0.1 \\
\hline Oman & 23.4 & 32.5 & 32.4 & 0.0 & -0.0 & 0.2 & 0.4 & 2.9 & 0.5 \\
\hline Singapore & 51.9 & 43.2 & 42.8 & 0.0 & -0.0 & 0.3 & 0.7 & 3.5 & 0.7 \\
\hline Uruguay & 9.6 & 17.8 & 17.8 & 0.0 & 0.0 & 0.0 & 0.4 & 1.5 & 1.8 \\
\hline Iran & 12.2 & 17.0 & 17.0 & -0.0 & -0.0 & 0.1 & 0.2 & 1.4 & 0.1 \\
\hline Brazil & 8.1 & 7.0 & 6.9 & -0.0 & -0.0 & 0.0 & 0.1 & 0.6 & 0.1 \\
\hline Cote d'Ivoire & 1.4 & 19.7 & 19.6 & -0.0 & -0.0 & 0.0 & 0.7 & 2.0 & 0.1 \\
\hline Sri Lanka & 3.7 & 23.1 & 22.8 & -0.0 & -0.0 & 0.1 & 0.3 & 1.6 & 1.2 \\
\hline Argentina & 11.6 & 12.0 & 11.9 & -0.0 & -0.0 & 0.0 & 0.3 & 1.3 & 0.2 \\
\hline Vietnam & 2.6 & 41.4 & 41.2 & -0.1 & -0.0 & 0.2 & 0.7 & 3.9 & 0.2 \\
\hline Rest of Frm. Sov. Union & & 18.9 & 18.9 & -0.1 & -0.0 & -0.0 & 0.2 & 2.2 & -0.6 \\
\hline Mexico & 12.9 & 15.2 & 14.7 & -0.1 & -0.0 & -0.0 & 0.3 & 1.1 & -0.1 \\
\hline South Central Africa & & 28.1 & 28.0 & -0.1 & 0.0 & 0.1 & 0.4 & 2.2 & 1.0 \\
\hline Indonesia & 3.5 & 13.4 & 13.3 & -0.1 & -0.0 & -0.0 & 0.1 & 0.9 & 0.6 \\
\hline Rest of East Asia & & 20.7 & 20.6 & -0.1 & -0.0 & -0.0 & 0.2 & 1.0 & -0.1 \\
\hline Rest of Southeast Asia & & 17.0 & 17.0 & -0.1 & -0.0 & -0.0 & 0.1 & 1.3 & -0.0 \\
\hline Zambia & 1.7 & 15.6 & 15.5 & -0.1 & -0.0 & -0.1 & 0.1 & 1.2 & 0.5 \\
\hline Saudi Arabia & 21.5 & 27.9 & 27.8 & -0.1 & -0.0 & 0.1 & 0.3 & 1.9 & 0.3 \\
\hline Japan & 31.7 & 8.3 & 8.1 & -0.1 & -0.0 & -0.1 & -0.0 & 0.4 & 0.3 \\
\hline Bangladesh & 1.3 & 13.9 & 13.6 & -0.1 & -0.0 & 0.1 & 0.3 & 1.4 & -0.6 \\
\hline Peru & 7.0 & 10.3 & 10.1 & -0.1 & -0.0 & -0.1 & 0.1 & 0.9 & -0.3 \\
\hline Rest of South America & & 25.0 & 24.5 & -0.2 & -0.0 & -0.2 & 0.6 & 2.4 & 7.0 \\
\hline Kuwait & 62.9 & 24.0 & 24.0 & -0.2 & -0.0 & 0.1 & 0.3 & 2.0 & 0.9 \\
\hline Mozambique & 0.7 & 31.0 & 30.9 & -0.2 & -0.0 & -0.2 & 0.4 & 2.4 & 1.5 \\
\hline Chile & 13.7 & 17.3 & 17.1 & -0.2 & -0.0 & -0.1 & 0.3 & 1.5 & -0.4 \\
\hline Costa Rica & 9.3 & 26.2 & 25.8 & -0.2 & -0.0 & 0.1 & 0.9 & 2.6 & -0.4 \\
\hline Korea, Republic of & 26.0 & 17.7 & 17.4 & -0.2 & -0.0 & -0.1 & 0.1 & 1.0 & 0.6 \\
\hline Philippines & 3.2 & 24.6 & 24.2 & -0.2 & -0.0 & 0.0 & 0.2 & 1.7 & -0.2 \\
\hline China & 6.6 & 10.8 & 10.6 & -0.3 & -0.0 & 0.0 & 0.2 & 1.1 & 0.4 \\
\hline Mongolia & 4.4 & 32.0 & 31.9 & -0.3 & -0.0 & -0.1 & 0.2 & 2.4 & 0.4 \\
\hline Thailand & 8.0 & 28.9 & 28.6 & -0.3 & -0.0 & -0.0 & 0.2 & 2.2 & 0.3 \\
\hline Taiwan & 28.2 & 26.9 & 26.6 & -0.4 & -0.0 & -0.0 & 0.2 & 1.6 & 1.0 \\
\hline Malaysia & 12.2 & 30.3 & 29.8 & -0.5 & -0.0 & -0.0 & 0.4 & 3.5 & 0.6 \\
\hline Rest of $\mathrm{SACU}^{a}$ & & 19.4 & 19.0 & -0.7 & -0.0 & -0.0 & -0.0 & 1.1 & 5.3 \\
\hline Cambodia & 1.8 & 34.2 & 33.2 & -0.9 & -0.0 & 0.2 & 0.4 & 3.1 & -1.0 \\
\hline
\end{tabular}

Note: The table provides an overview of the country-specific effects of different TTIP scenarios.

${ }^{a}$ SACU stands for Southern African Customs Union. 


\section{A Regional and sectoral breakdown}

Countries and regions in GTAP The 114 countries in GTAP are: Albania, Argentina, Armenia, Australia, Austria, Azerbaijan, Bangladesh, Belarus, Belgium, Benin, Bolivia, Botswana, Brazil, Bulgaria, Burkina Faso, Cambodia, Cameroon, Canada, Chile, China, Colombia, Costa Rica, Cote d Ivoire, Croatia, Cyprus, Czech Republic, Denmark, Ecuador, Egypt, El Salvador, Estonia, Ethiopia, Finland, France, Georgia, Germany, Ghana, Greece, Guatemala, Guinea, Honduras, Hong Kong, Hungary, India, Indonesia, Iran, Ireland, Israel, Italy, Japan, Kazakhstan, Kenya, Kuwait, Kyrgyzstan, Laos, Latvia, Lithuania, Luxembourg, Madagascar, Malawi, Malaysia, Malta, Mauritius, Mexico, Mongolia, Morocco, Mozambique, Namibia, Nepal, Netherlands, New Zealand, Nicaragua, Nigeria, Norway, Oman, Pakistan, Panama, Paraguay, Peru, Philippines, Poland, Portugal, Qatar, Russian Federation, Rwanda, Saudi Arabia, Senegal, Singapore, Slovakia, Slovenia, South Africa, South Korea, Spain, Sri Lanka, Sweden, Switzerland, Taiwan, Tanzania, Thailand, Togo, Tunisia, Turkey, Uganda, Ukraine, United Arab Emirates, United Kingdom, United States of America, Uruguay, Venezuela, Vietnam, Zambia and Zimbabwe.

Other countries are aggregated into 20 regional composites such as, e.g., Rest of Southeast Asia comprising Brunei Darussalam, Myanmar, and Timor Leste.

Region listing The following list provides an overview of the regional breakdown we use to present the results. Note that the simulations are performed with the 134 original GTAP countries and regions, though.

- ASEAN: Indonesia, Cambodia, Laos, Malaysia, Philippines, Singapore, Thailand, Vietnam, Rest of Southeast Asia (Brunei Darussalam, Myanmar, Timor Leste ${ }^{1}$ )

\footnotetext{
${ }^{1}$ Timor Leste is not part of ASEAN. However, in GTAP's regional breakdown it is included in the region "Rest of Southeast Asia" together with Brunei Darussalam and Myanmar, both ASEAN member states. Therefore, we assigned the region "Rest of Southeast Asia" to ASEAN.
} 
- Central Asia: Azerbaijan, Georgia, Kyrgyzstan, Ukraine, Mongolia, Rest of Eastern Europe (Moldova), Rest of Former Soviet Union (Tajikistan, Turkmenistan, Uzbekistan)

- China: China, Hong Kong

- East Asia: Japan, South Korea, Taiwan

- EFTA: Norway, Switzerland, Rest of EFTA (Iceland, Liechtenstein)

- Eurasian Customs Union: Armenia, Belarus, Kazakhstan, Russian Federation

- Latin America \& Caribbean: Bolivia, Ecuador, Guatemala, Honduras, Nicaragua, Panama, El Salvador, Rest of Central America (Belize), Rest of South America (Falkland Islands, French Guiana, Guyana, South Georgia and the South Sandwich Islands, Suriname), Caribbean (Anguilla, Antigua \& Barbuda, Aruba, Bahamas, Barbados, Cayman Islands, Cuba, Dominica, Dominican Republic, Grenada, Haiti, Jamaica, Montserrat, Netherlands Antilles, Puerto Rico, Saint Kitts and Nevis, Saint Lucia, Saint Vincent and the Grenadines, Trinidad and Tobago, Turks and Caicos Islands, Virgin Islands British, Virgin Islands U.S.)

- MERCOSUR: Argentina, Brazil, Paraguay, Uruguay, Venezuela

- Middle East \& North Africa: Israel, Egypt, Iran, Morocco, Tunisia, Rest of North Africa (Algeria, Libyan Arab Jamahiriya, Western Sahara), Rest of Western Asia (Iraq, Jordan, Lebanon, Palestinian Territory Occupied, Syrian Arab Republic, Yemen)

- Oil exporters: United Arab Emirates, Bahrain, Kuwait, Oman, Qatar, Saudi Arabia

- Pacific Alliance: Chile, Colombia, Costa Rica, Mexico, Peru 
- Rest of Europe: Albania, Croatia, Rest of Europe (Andorra, Bosnia and Herzegovina, Faroe Islands, Gibraltar, Guernsey, Holy See, Isle of Man, Jersey, Former Yugoslav Republic of Macedonia, Monaco, Montenegro, San Marino, Serbia)

- Rest of Oceania: Rest of Oceania (American Samoa, Cook Islands, Fiji, French Polynesia, Guam, Kiribati, Marshall Islands, Micronesia Federated States of, Nauru, New Caledonia, Niue, Northern Mariana Islands, Palau, Papua New Guinea, Pitcairn, Samoa, Solomon Islands, Tokelau, Tonga, Tuvalu, United States Minor Outlying Islands, Vanuatu, Wallis and Futuna)

- Rest of World: Rest of East Asia (Democratic People's Republic of Korea, Macao), Rest of South Asia (Afghanistan, Bhutan, Maldives), Rest of North America (Bermuda, Greenland, Saint Pierre and Miquelon), Rest of the World (Antarctica, Bouvet Island, British Indian Ocean Territory, French Southern Territories)

- South Asia: Bangladesh, India, Sri Lanka, Nepal, Pakistan

- Southern African Customs Union: Botswana, Namibia, South Africa, Rest of South African Customs Union (Lesotho, Swaziland)

- Sub-Saharan Africa: Benin, Burkina Faso, Ivory Coast, Ethiopia, Cameroon, Ghana, Guinea Bissau, Kenya, Madagascar, Mozambique, Nigeria, Malawi, Mauritius, Rwanda, Senegal, Togo, Tanzania, Uganda, Rest of Western Africa (Cape Verde, Gambia, Liberia, Mali, Mauritania, Niger, Saint Helena, Ascension and Tristan Da Cunha, Sierra Leone), Central Africa (Central African Republic, Chad, Congo, Equatorial Guinea, Gabon, Sao Tome and Principe), South Central Africa (Angola, Congo the Democratic Republic of), Rest of Eastern Africa (Burundi, Comoros, Djibouti, Eritrea, Mayotte, Seychelles, Somalia, Sudan) 
Table A2: Overview of sectors

\begin{tabular}{|c|c|c|}
\hline & GTAP sector & Sector description \\
\hline 1 & $1-14,19,20,23$ & Agriculture \& Food \\
\hline 2 & $15-18$ & Mining \\
\hline 3 & $21,22,24-26$ & Food, processed \\
\hline 4 & $27+28$ & Textiles \& Wearing apparel \\
\hline 5 & 29 & Leather \\
\hline 6 & 30 & Wood \\
\hline 7 & 31 & Paper \\
\hline 8 & 32 & Petroleum \\
\hline 9 & 33 & Chemicals \\
\hline 10 & 34 & Mineral products \\
\hline 11 & 35 & Ferrous metals \\
\hline 12 & 36 & Metals nec \\
\hline 13 & 37 & Metal products \\
\hline 14 & $38+39$ & Transport equipment \\
\hline 15 & 40 & Electronics \\
\hline 16 & 41 & Machinery nec \\
\hline 17 & 42 & Manufactures nec \\
\hline 18 & 43 & Electricity \\
\hline 19 & 44 & Gas \\
\hline 20 & 45 & Water \\
\hline 21 & 46 & Construction \\
\hline 22 & 47 & Trade services \\
\hline 23 & 48 & Transport nec \\
\hline 24 & 49 & Water Transport \\
\hline 25 & 50 & Air Transport \\
\hline 26 & 51 & Communication \\
\hline 27 & 52 & Financial services nec \\
\hline 28 & 53 & Insurance \\
\hline 29 & 54 & Business services nec \\
\hline 30 & 55 & Recreational services \\
\hline 31 & 56 & Other services \\
\hline 32 & 57 & Dwellings \\
\hline
\end{tabular}

Note: The table provides an overview of the sectoral aggregation used throughout this publication. There are one agricultural and one resource extraction sector, 15 manufacturing sectors and 15 services sectors. 
B Detailed estimation results 


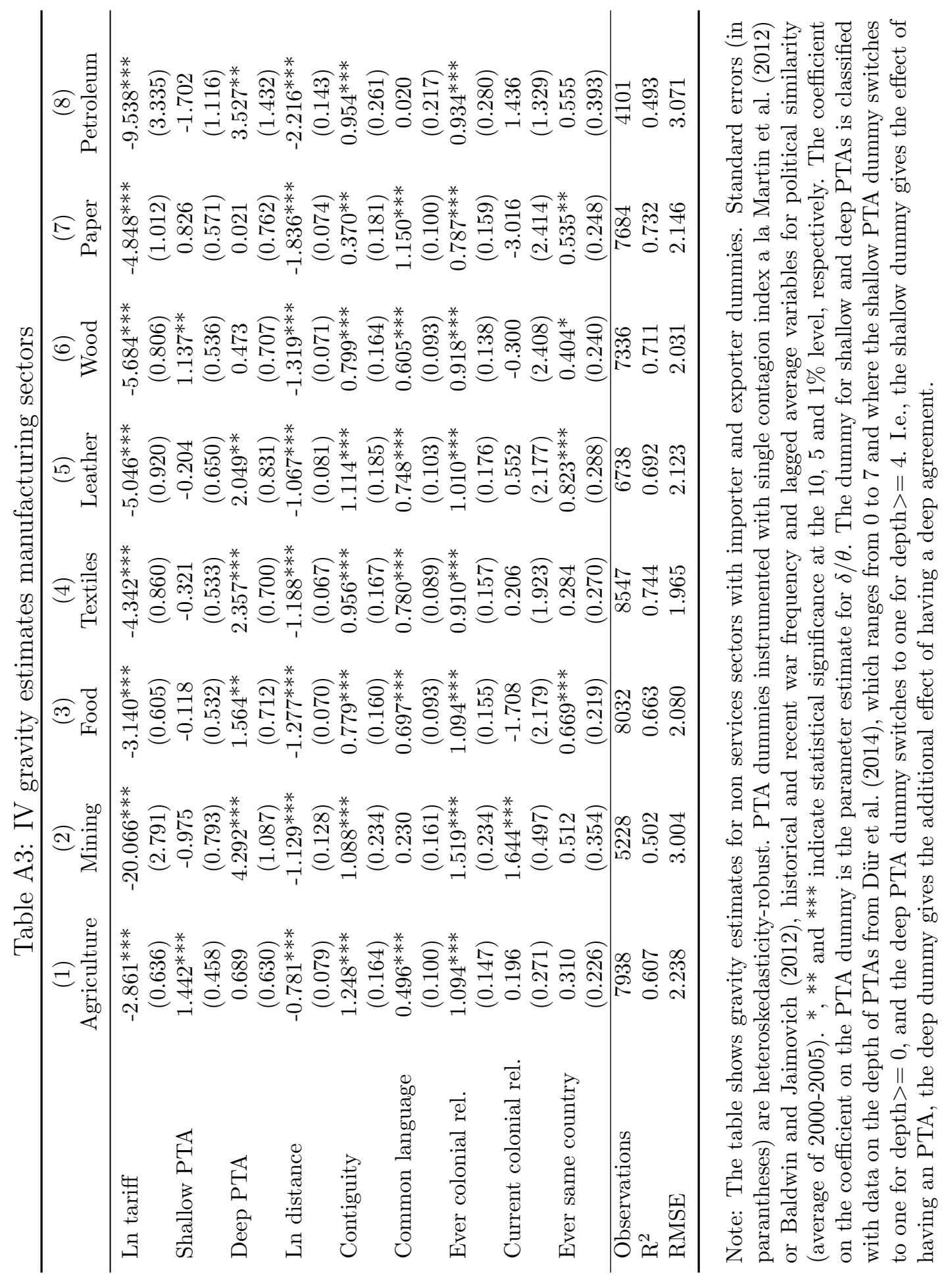




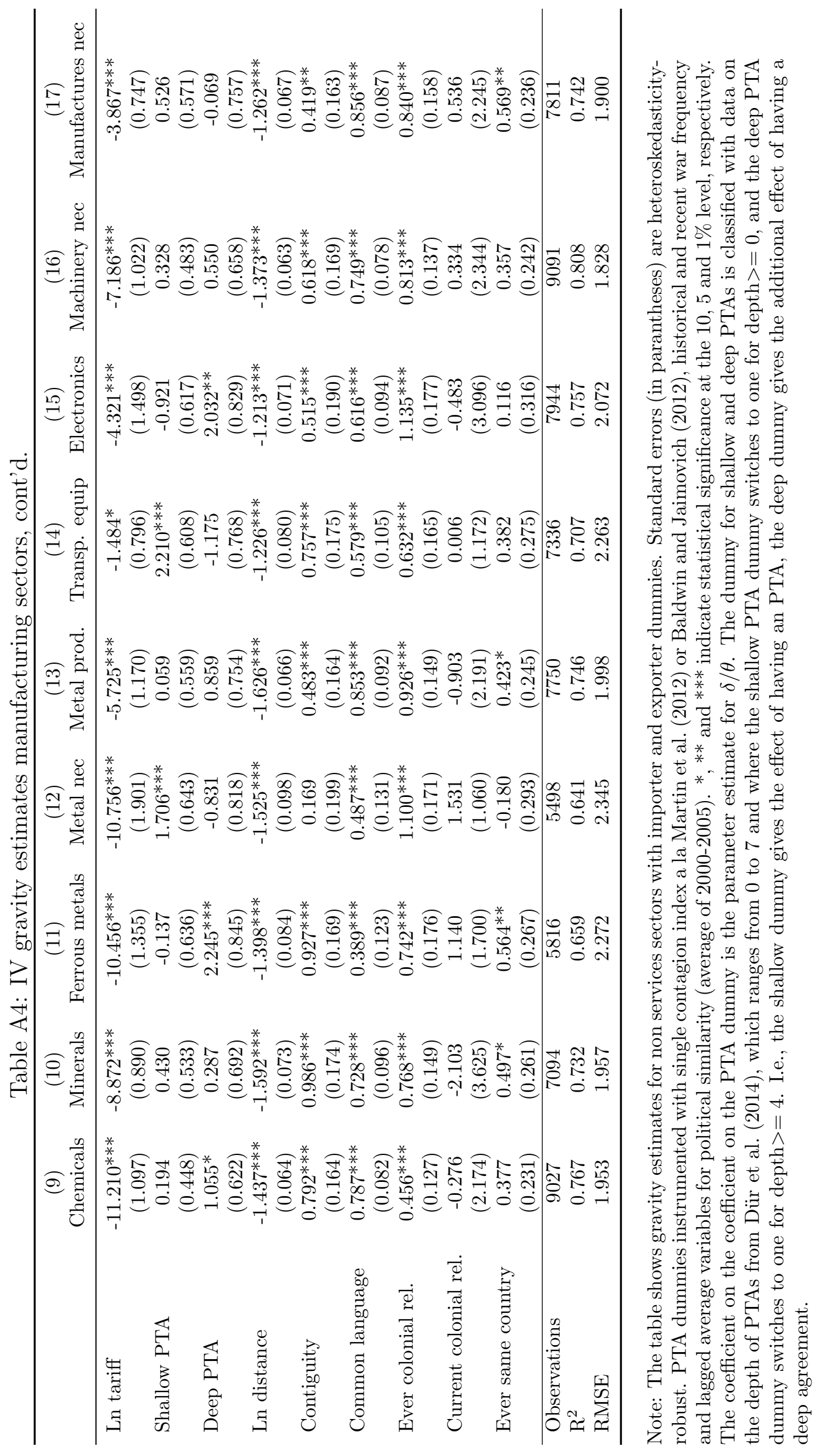




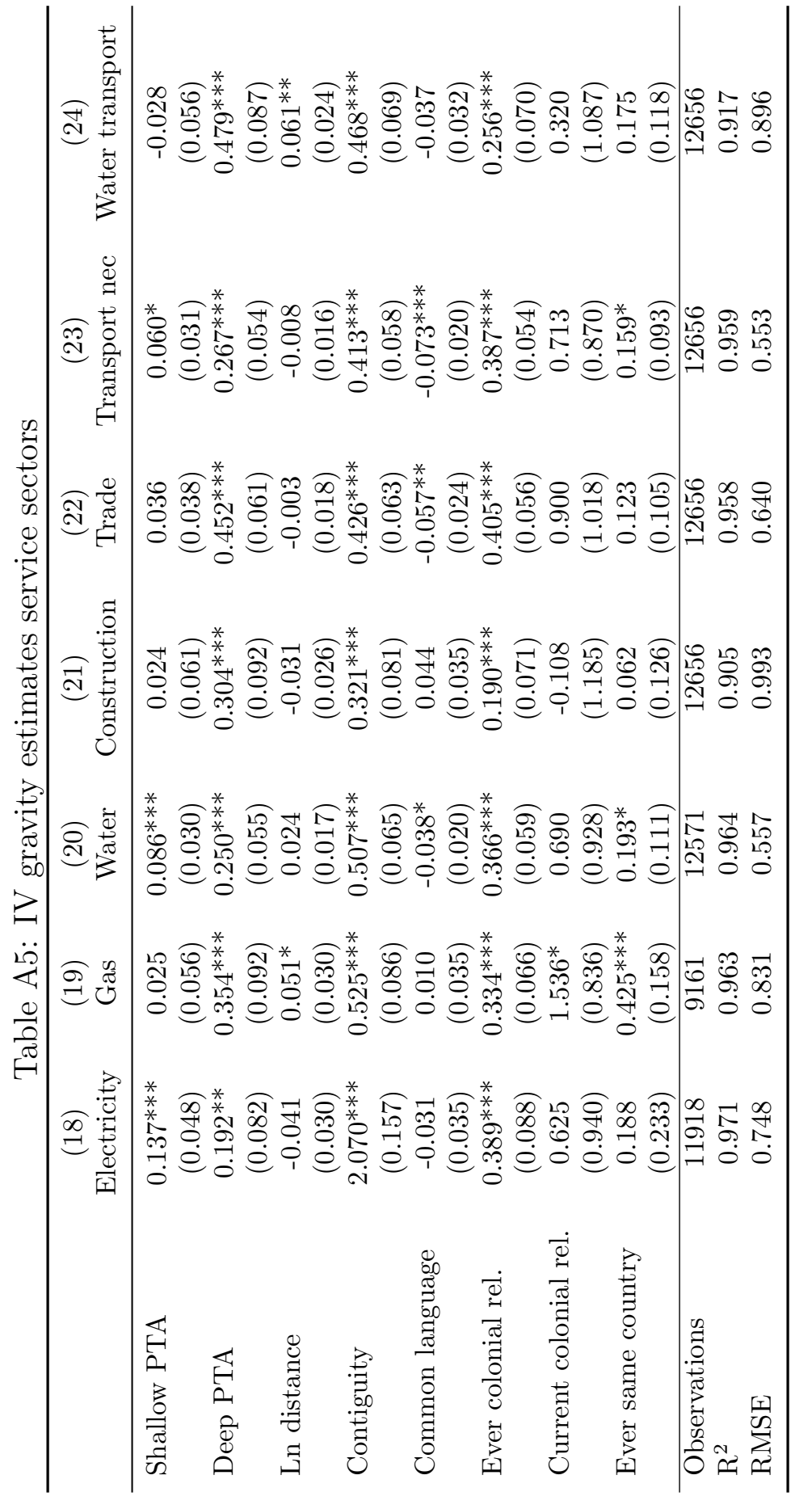

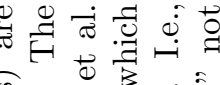

कु

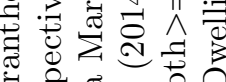

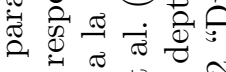

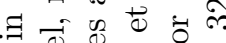

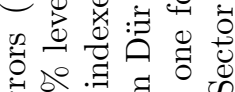

형

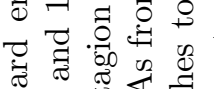

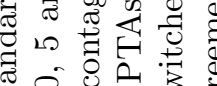

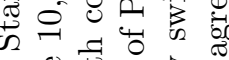

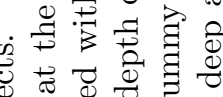

噧

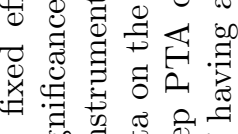

$\overrightarrow{0} .00$.

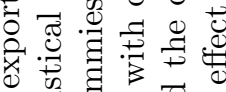

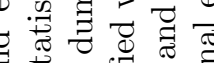

क

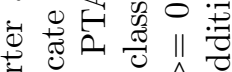

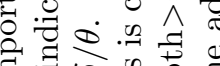

家: 10 事

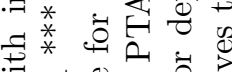

讨

跣

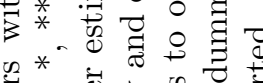

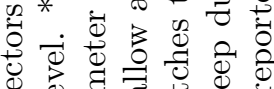

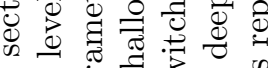

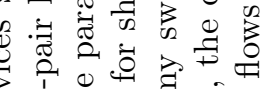

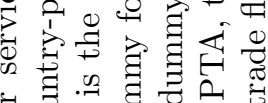

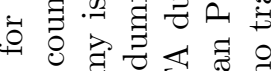

\%

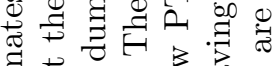

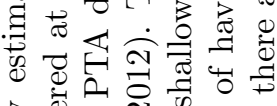

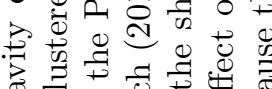

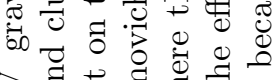

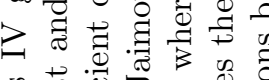

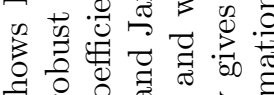

क

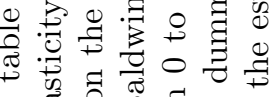

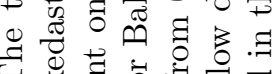

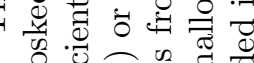

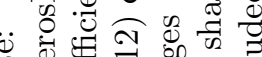

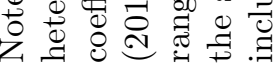




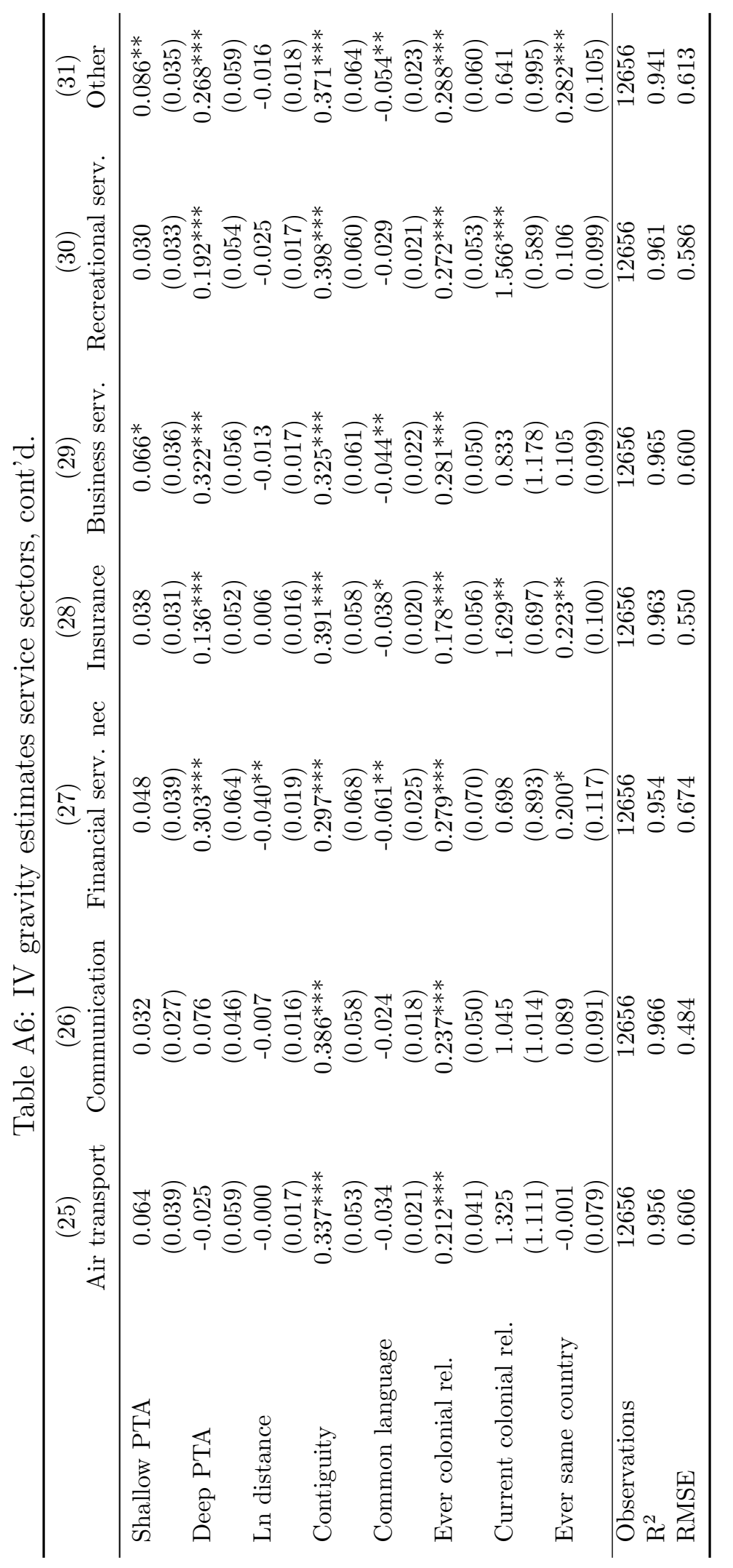

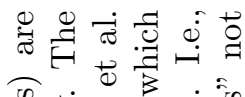

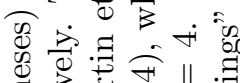

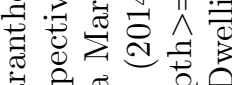

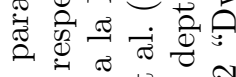

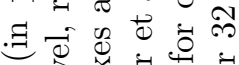

녕

解

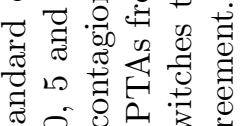

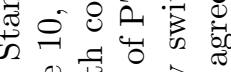

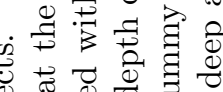

递

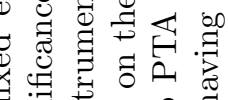

焉

可 $\frac{50 .}{\sigma}$.

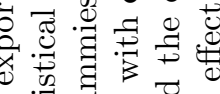

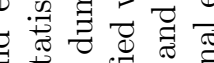

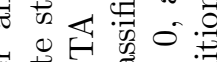

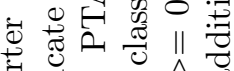

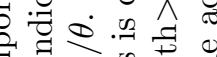

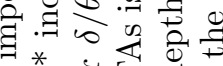

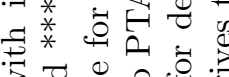

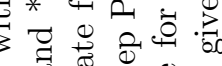

풀

** 范

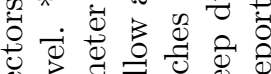

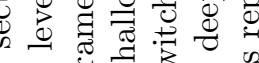

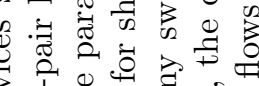

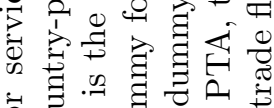

엉 응

ष

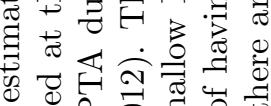

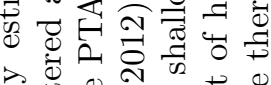

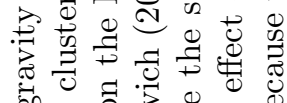

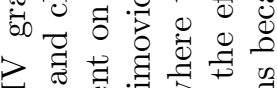

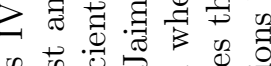

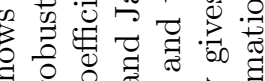

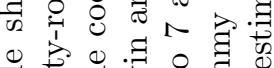

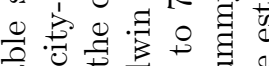

露

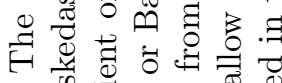

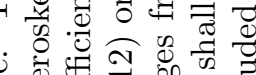

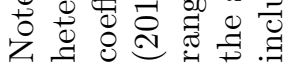




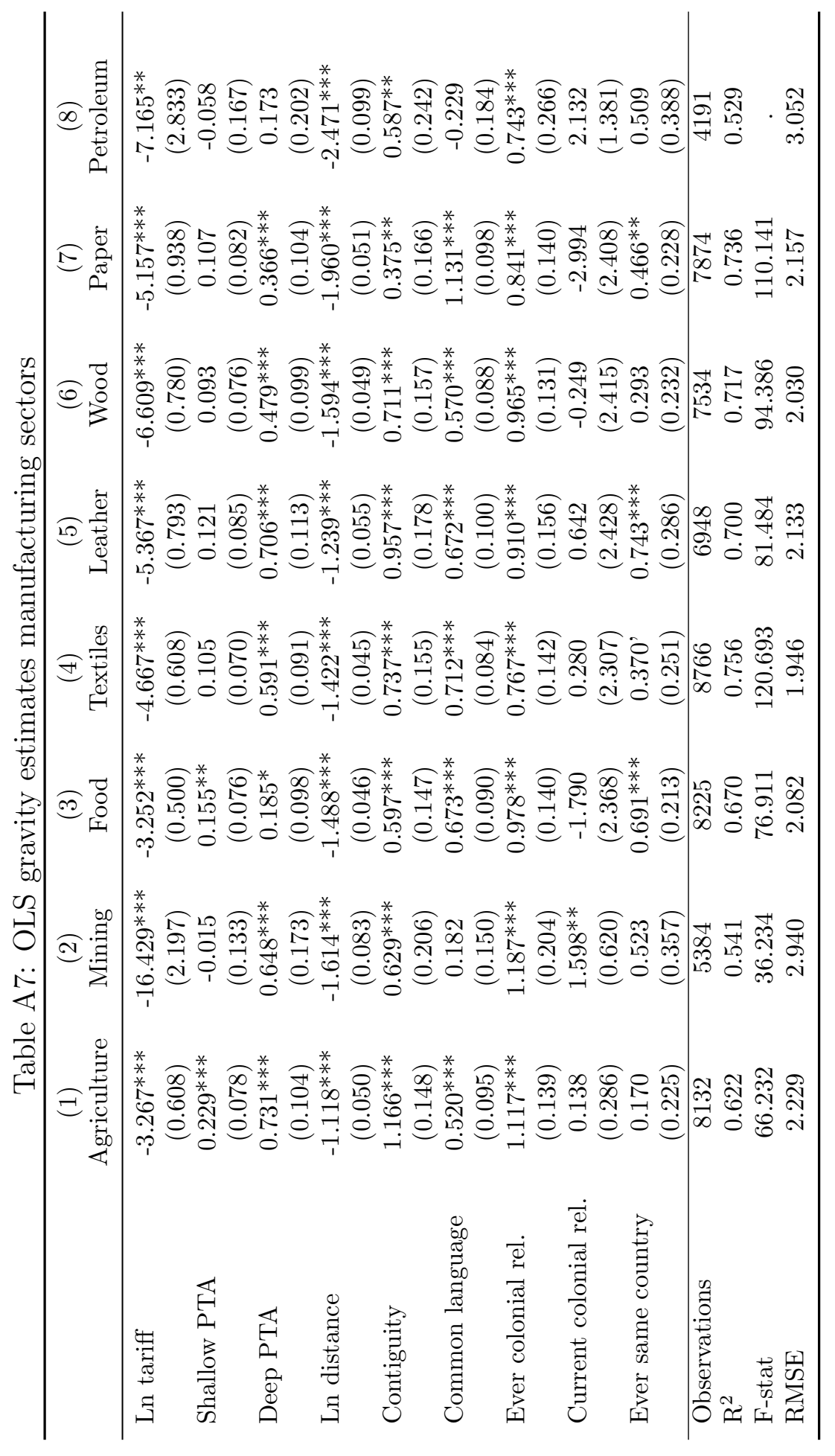

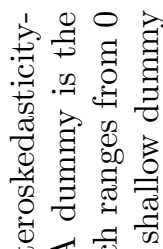

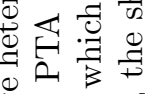

䒕昰宁

矛

营苞的

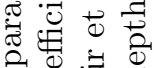

छ

용 용

屯

芯氙苨里

สี

क 跣

幽 过

寻

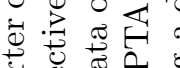

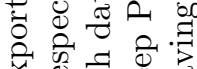

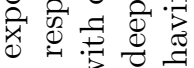

चี

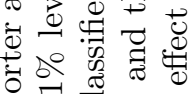

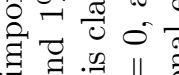

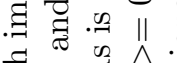

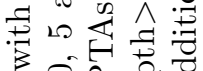

की

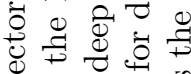

क స च

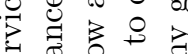

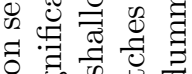

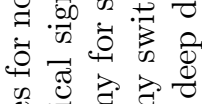

농 द्व

墕声寻

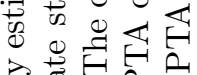

焉 $E$

胥事

*

क*

常

其*

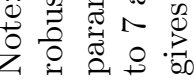




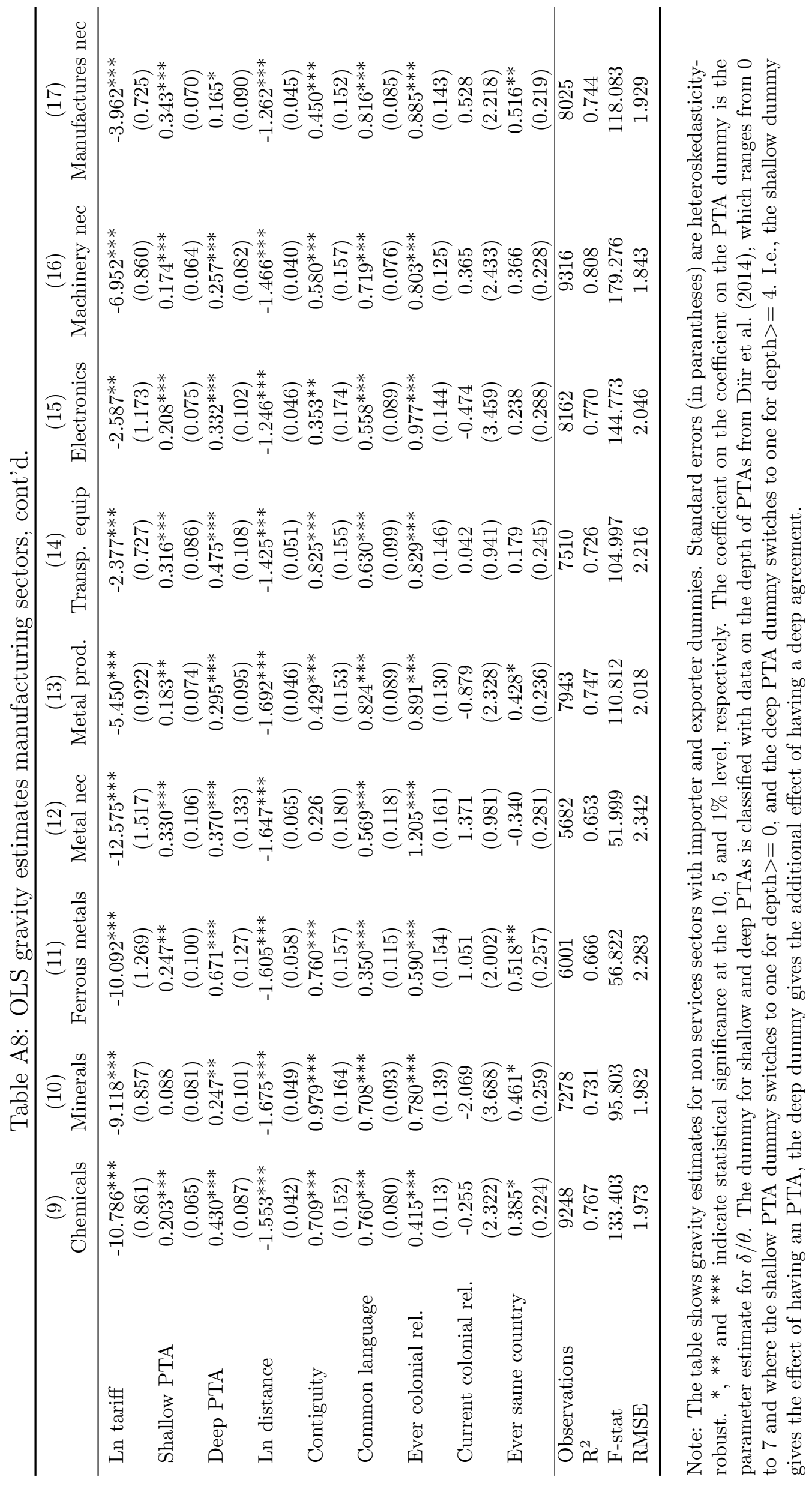




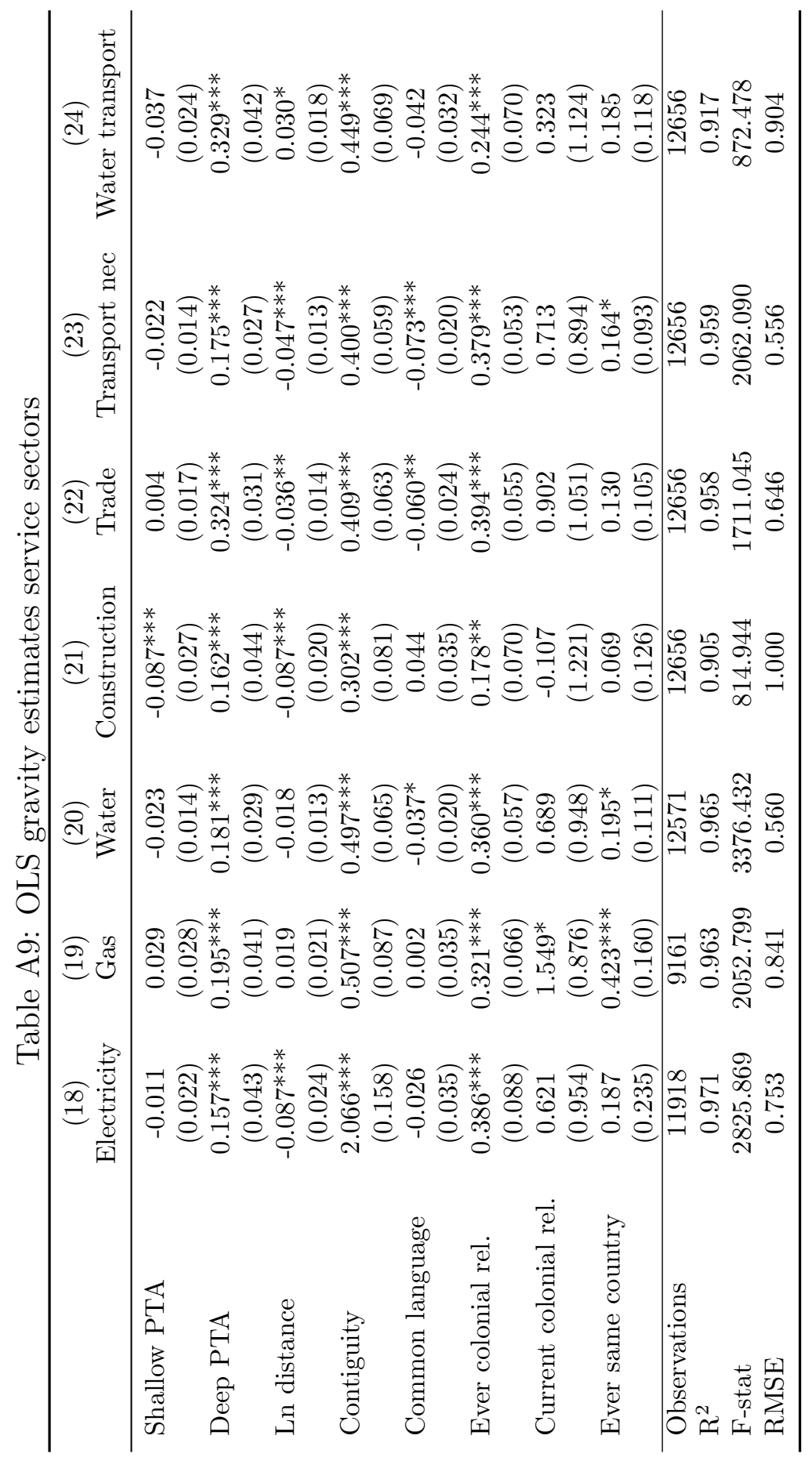

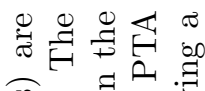

可

专

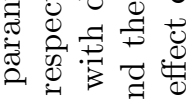

$\Xi-\widetilde{\sigma}$

妿

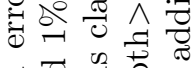

चีّ

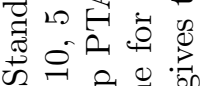
की 以ु 证

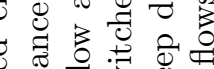

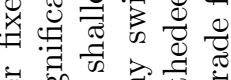
可器

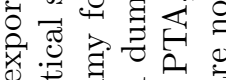

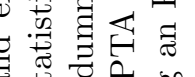

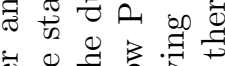

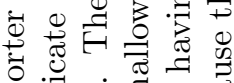

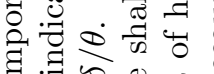
*

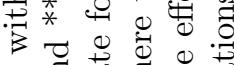

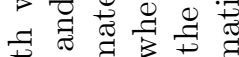

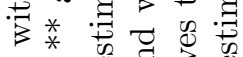

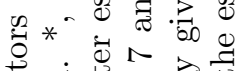

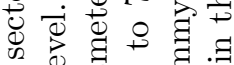

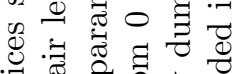

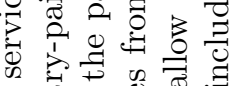

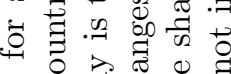

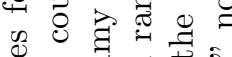
进象

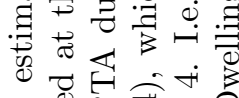

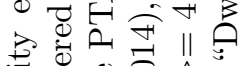

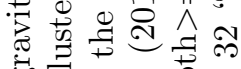
on 형

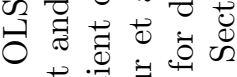

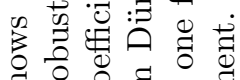
ज

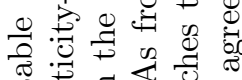

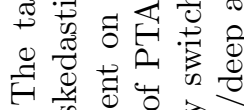

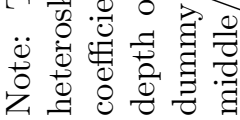




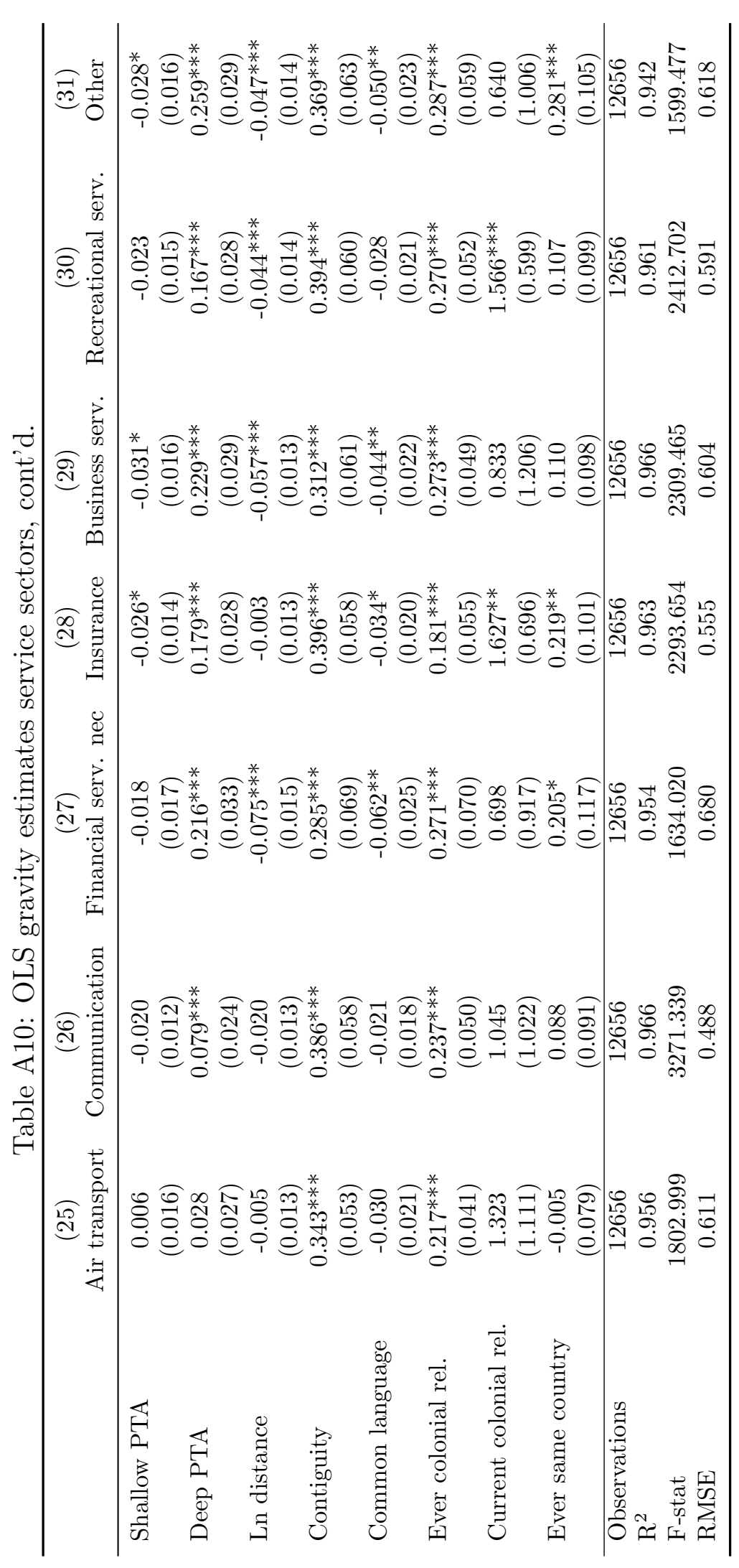

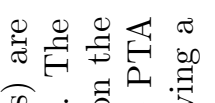

प्रे

要击

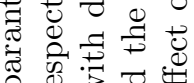

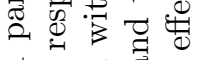

$\exists \overrightarrow{0} 0$ 焉

낸

웜

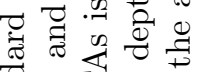

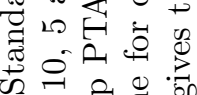

is 의 0

$\dot{0}$

눙

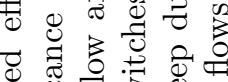

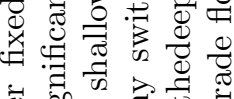

प. .000

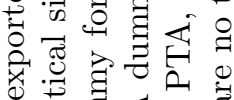

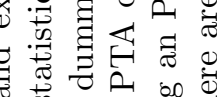

क 8.0

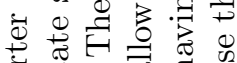

过.

$\exists=\infty \begin{aligned} & 0 \\ & *\end{aligned}$

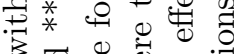

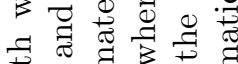

* $\cdot \overrightarrow{0}$ o

* *

过苛。运

ళ

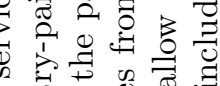

苛言.

\% 8 荘

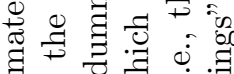

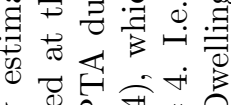

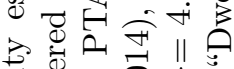

究总

50 ठ

ऽ

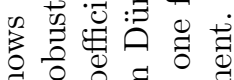

击

兽要

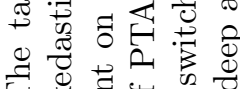

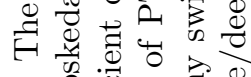

苍造造营 


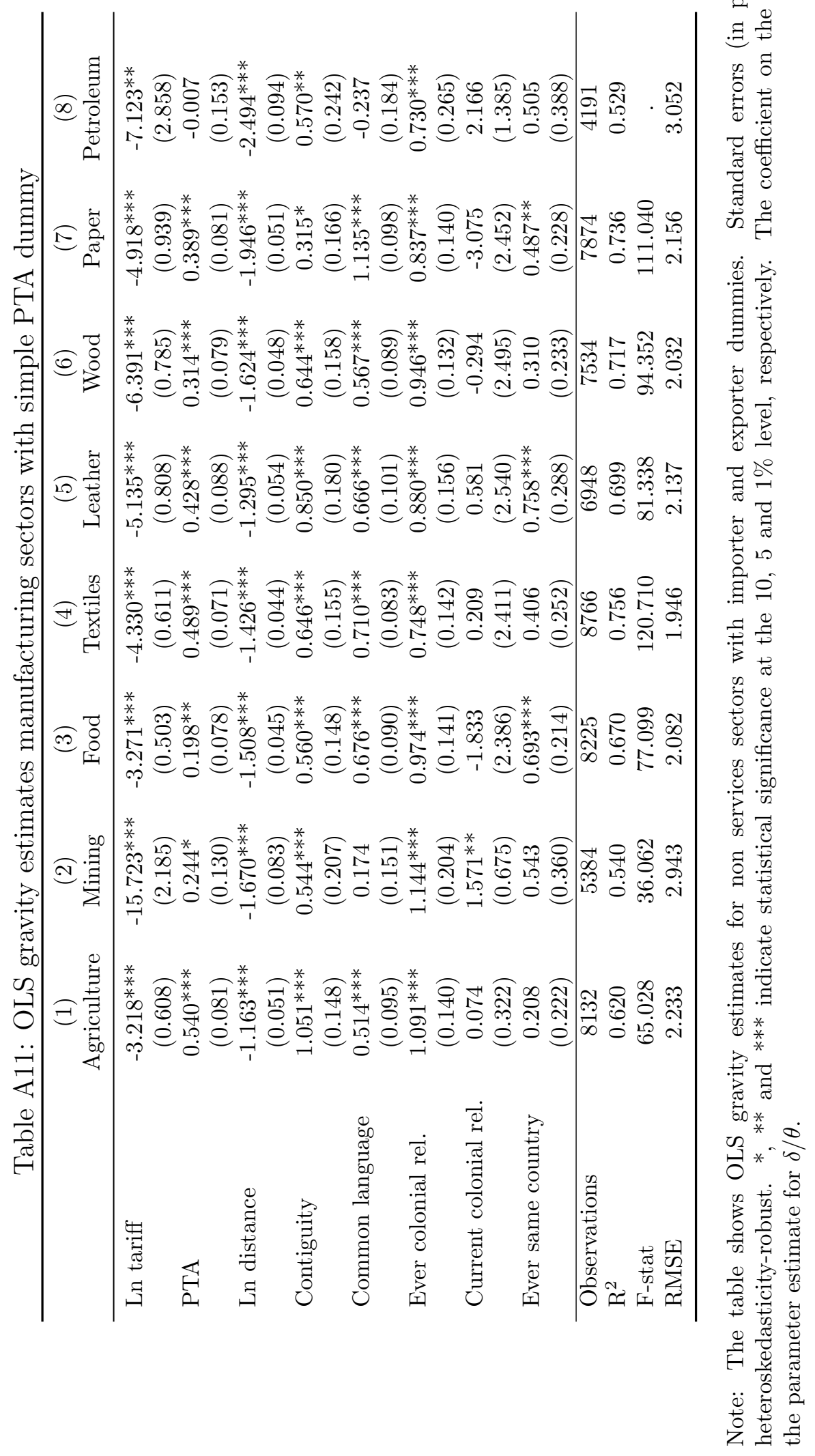




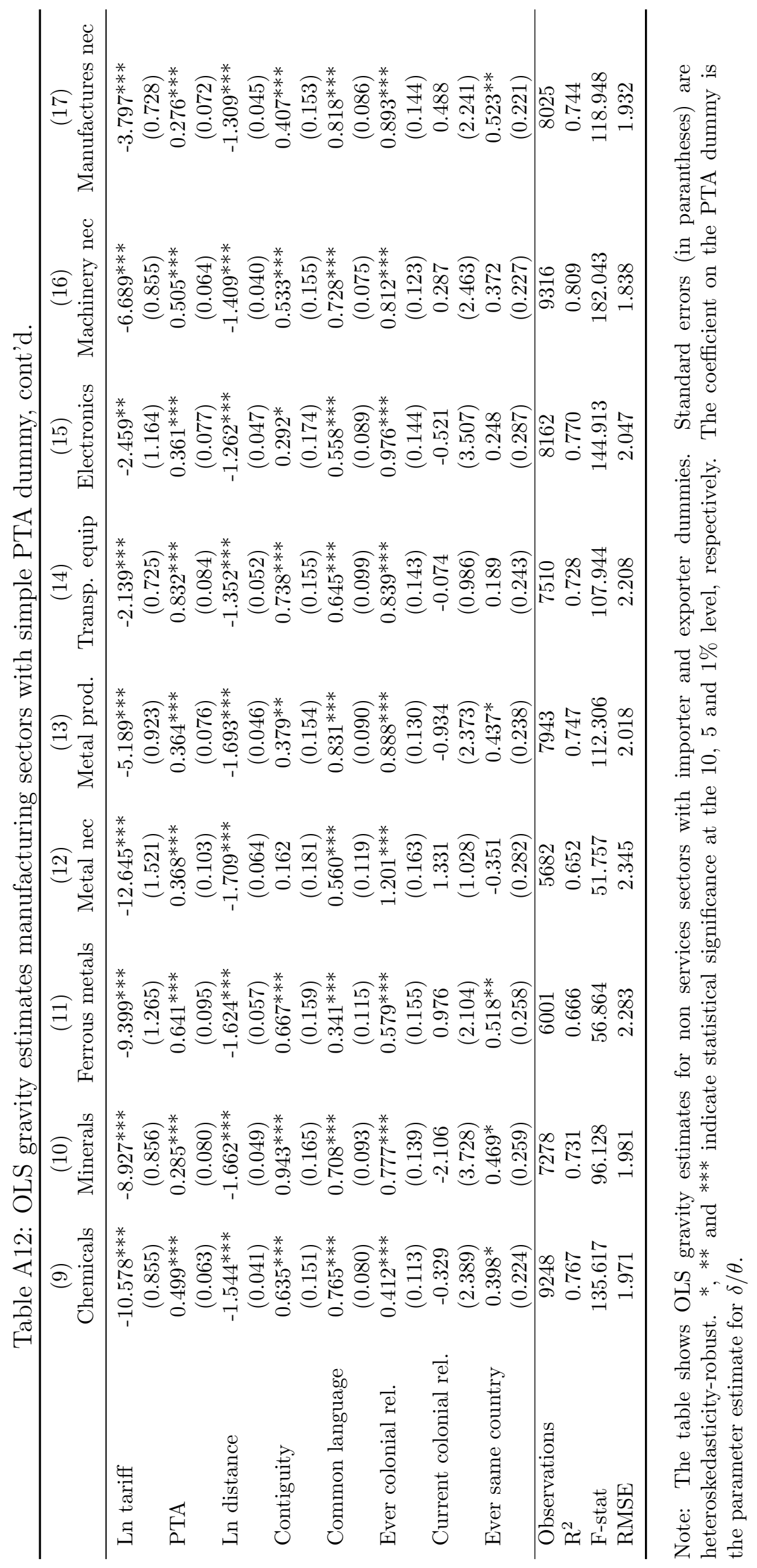




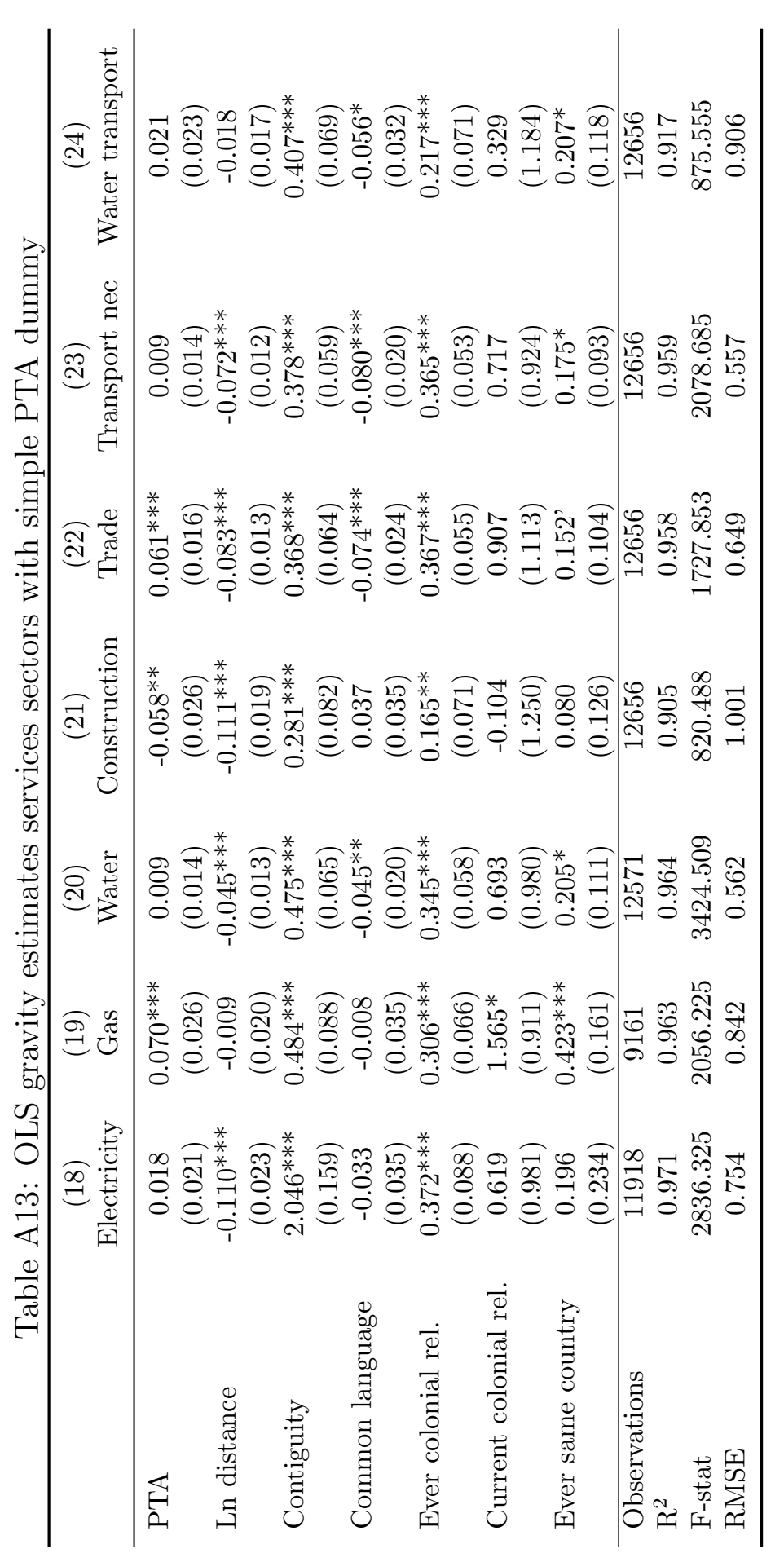

范

(⿹丁口).

黄

Фّ

$\exists$

क्षํㅇ

ㅎํㅇ

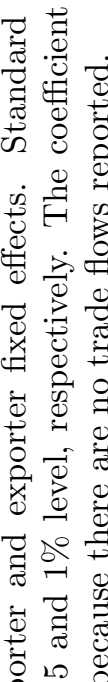

要 10

듈 올 윰

ᄃ

.

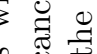

응.

证.

马ु 큐

尊.

co is

总: 要

范䒹

คำ

$50 *$ *

$0^{*} \cdot \dot{0}$

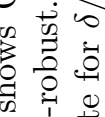

w

o

E

苍芯 


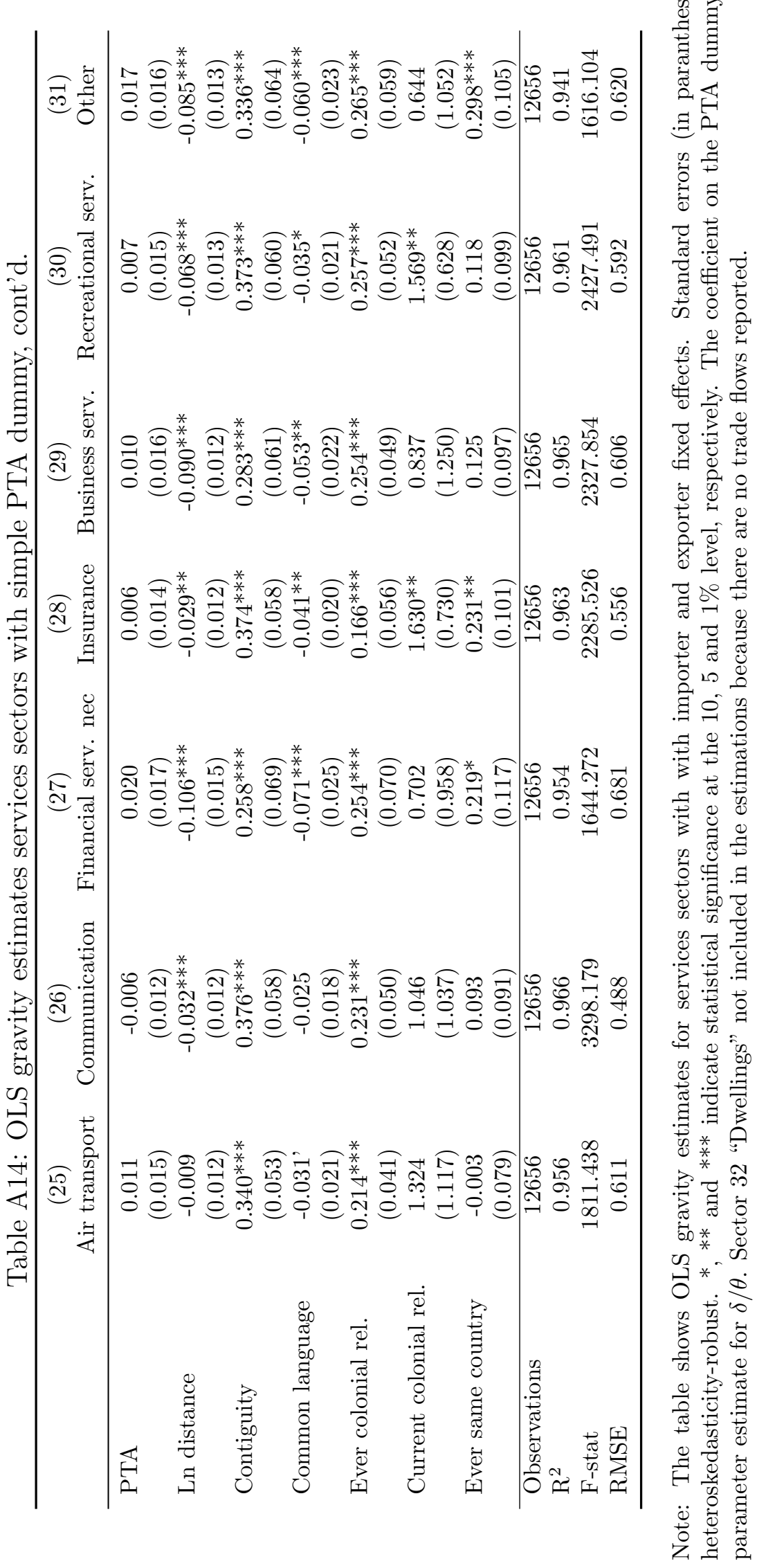




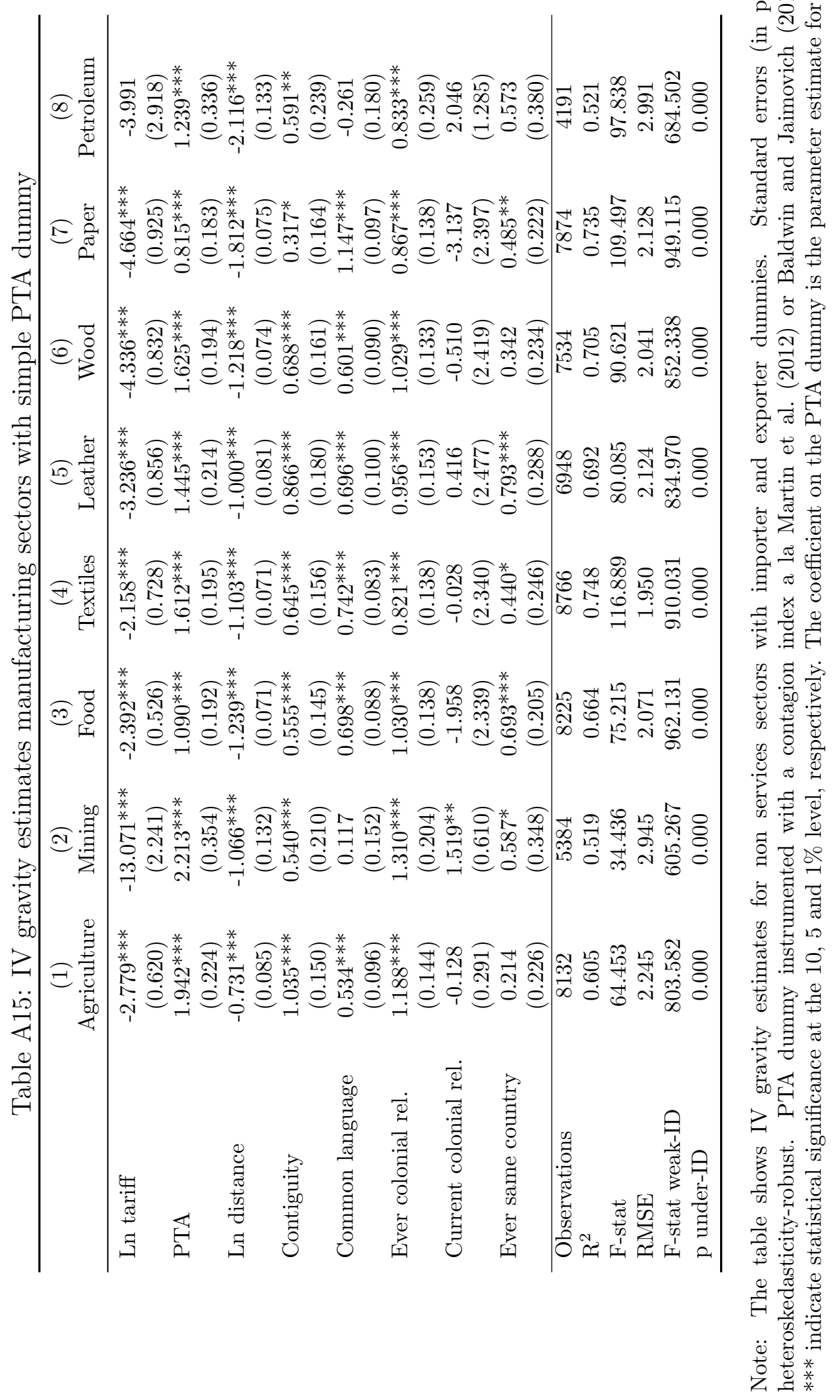




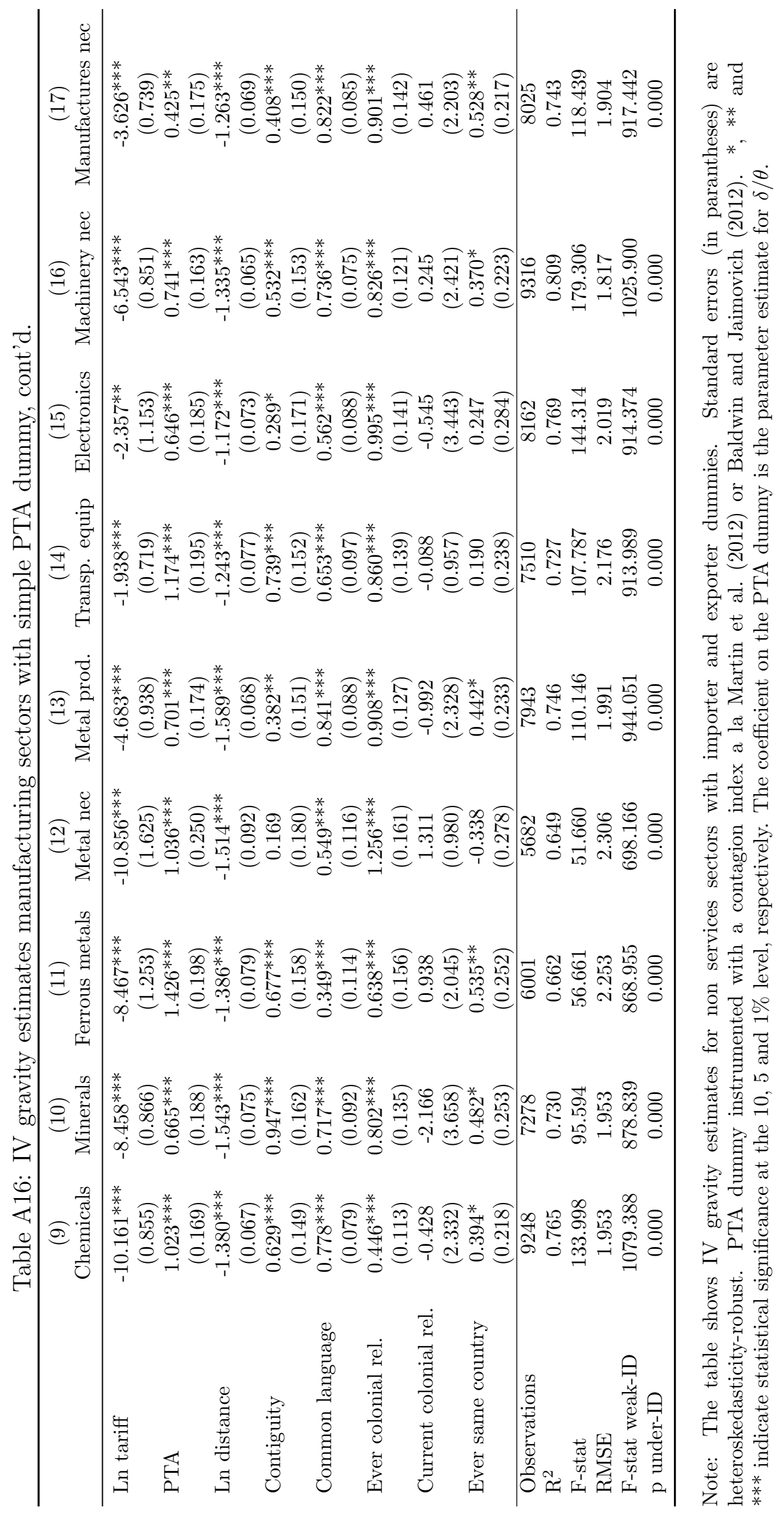




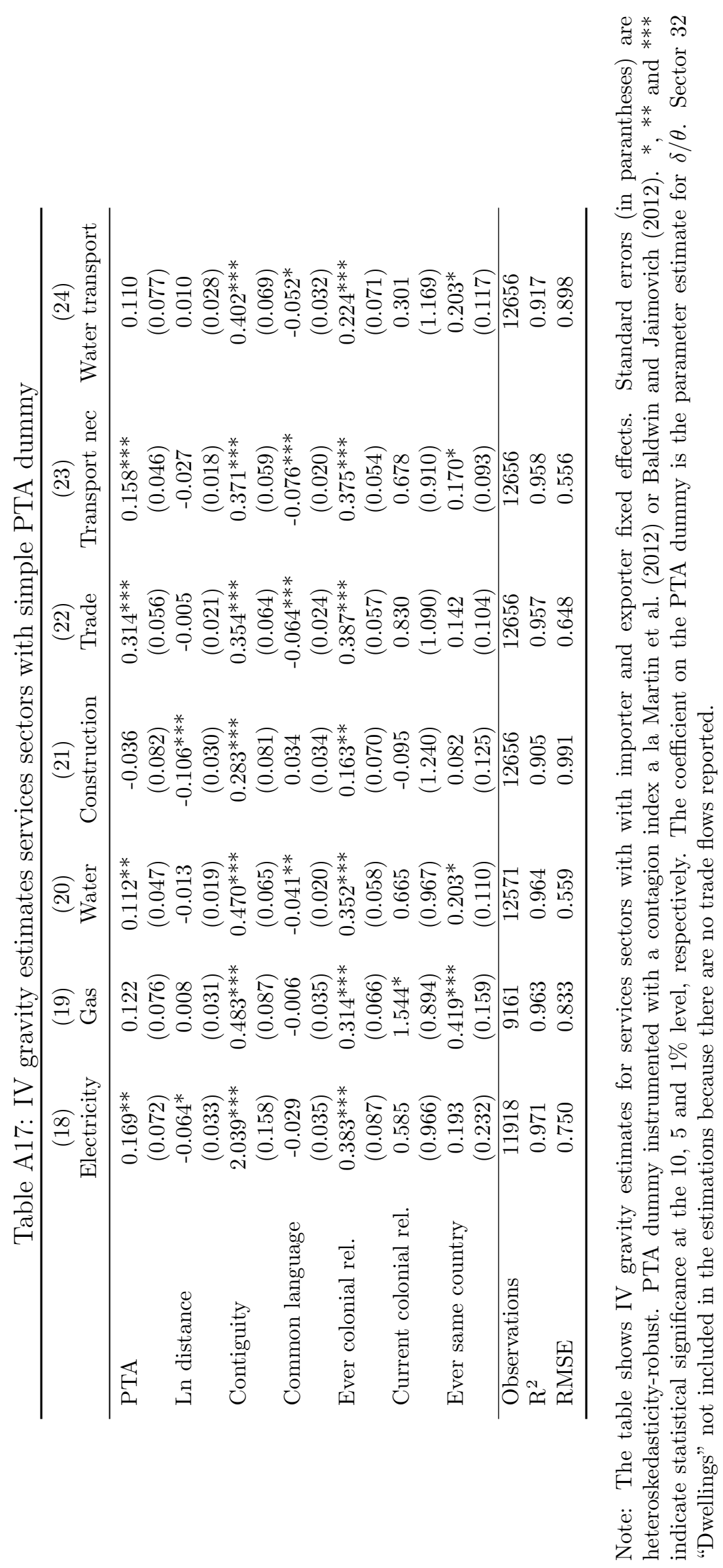




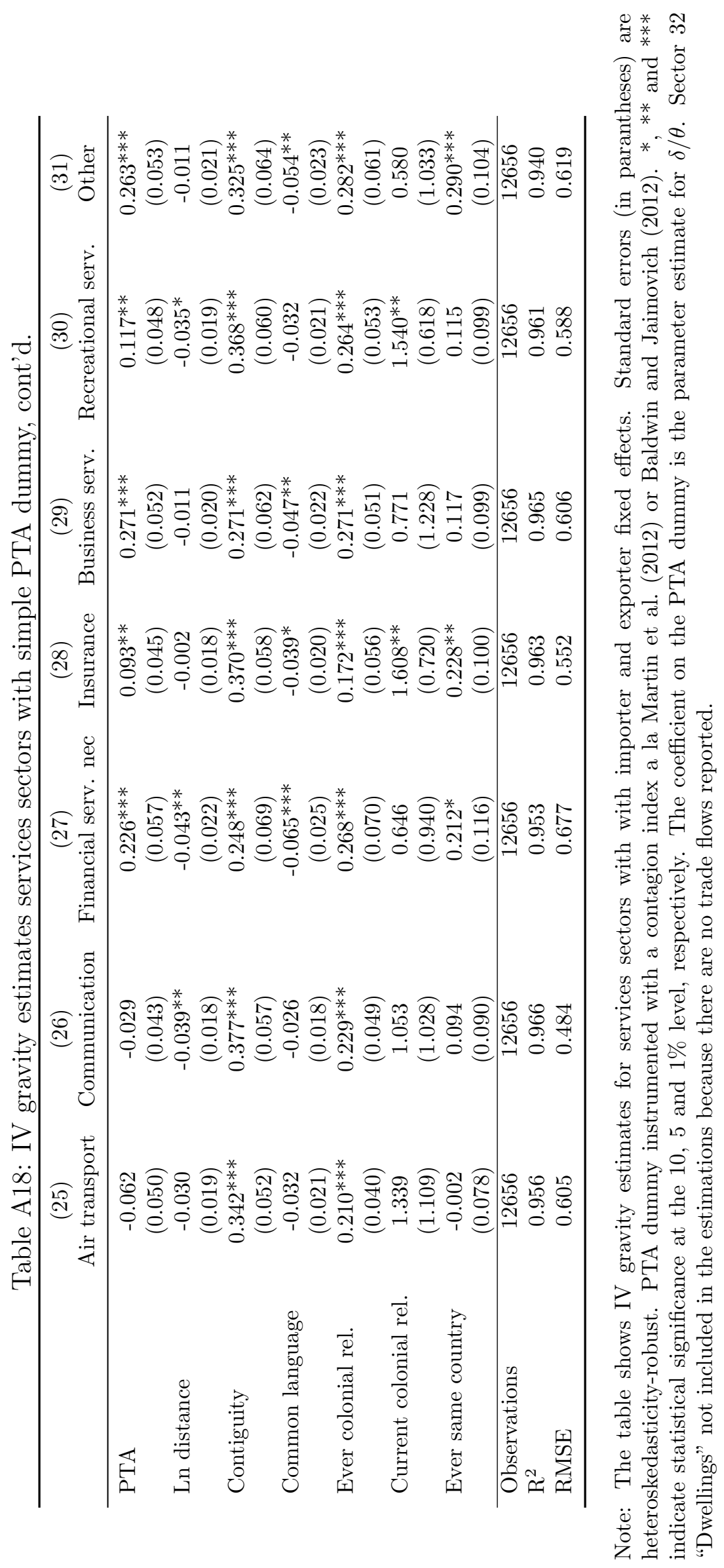




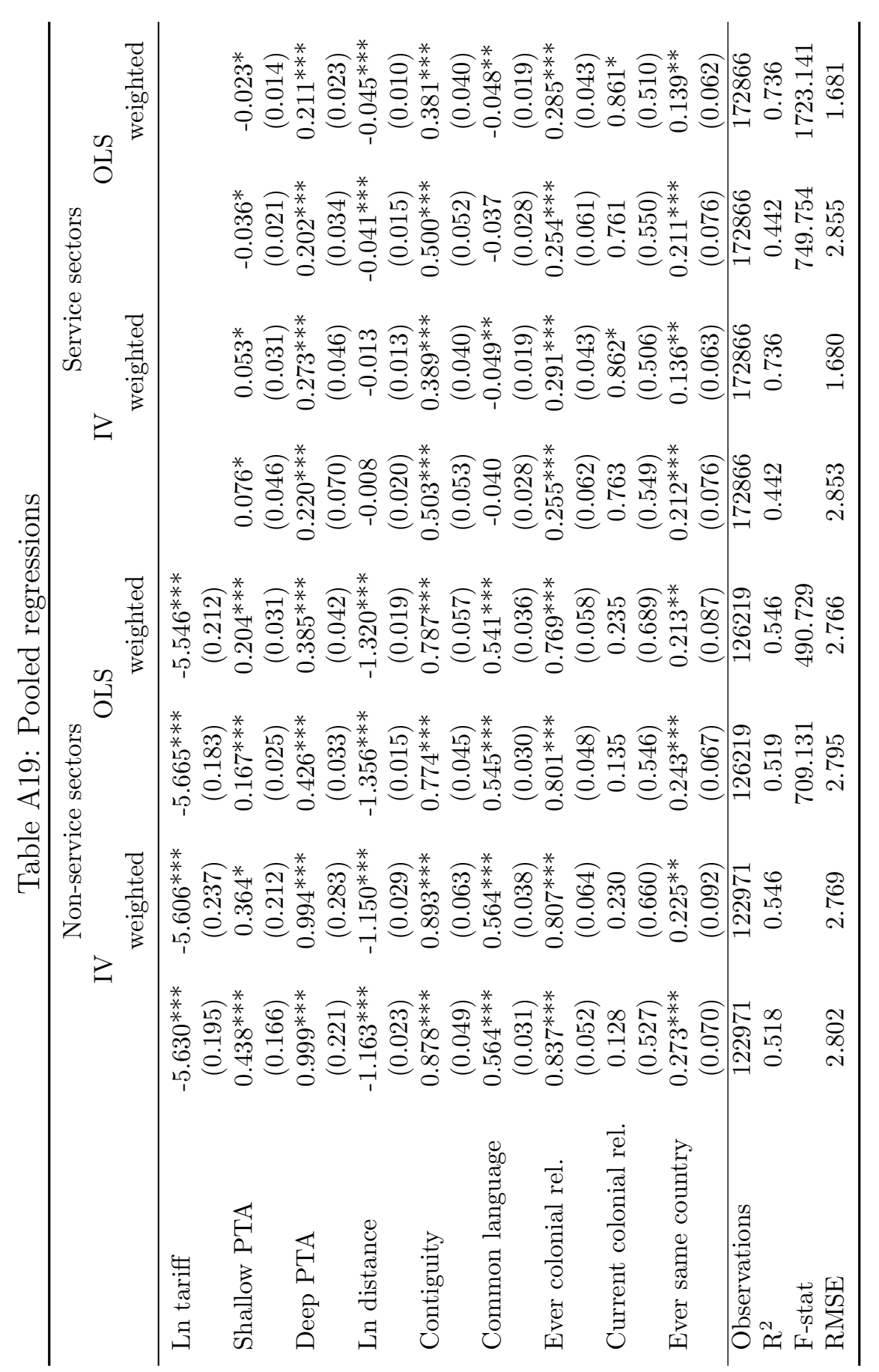

তี

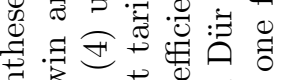
节 药

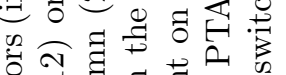

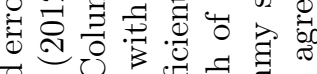

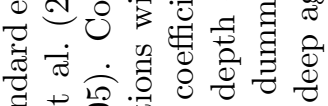

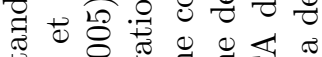

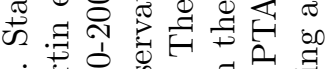

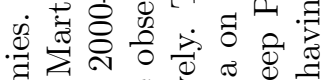
进 छ $\approx 0.000$

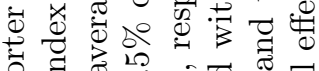

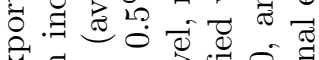

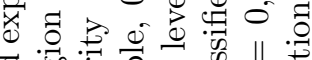

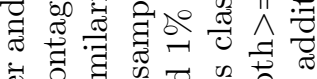

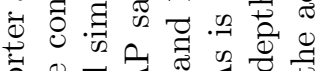

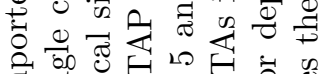

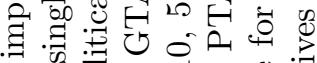
全

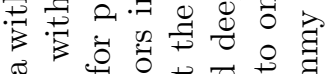

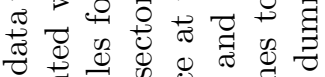

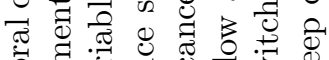

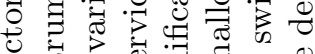

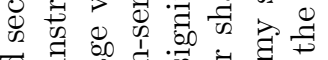

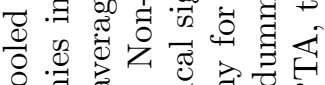

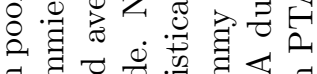

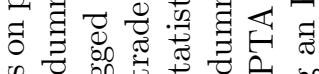

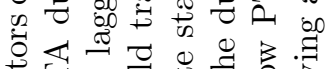

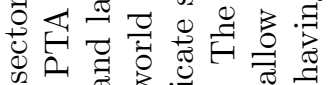

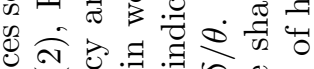

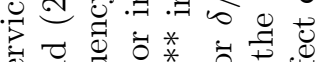

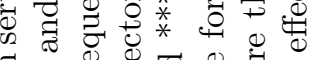

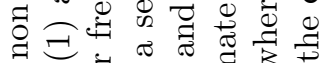

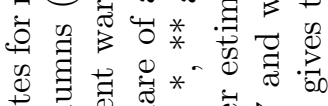

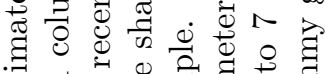

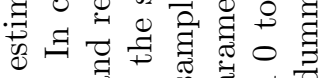

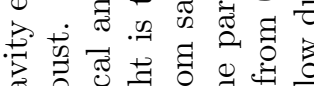

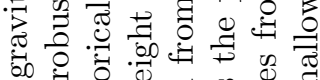
का

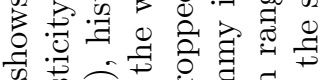
ज㻤 苛

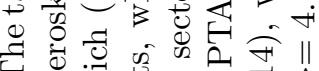
F

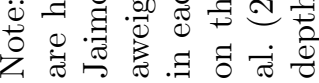




\section{Sensitivity checks: welfare effects from alternative empirical specifications}

The results presented so far rely on the PTA coefficients and $\theta$ s estimated with an IV approach and using two different depths of PTAs. Next, we investigate the sensitivity of the results pertaining to this choice. Table A20 presents results for three different empirical specifications. In column (1) and (2), the simulations are based on a single PTA dummy. In Column (1), the PTA dummy is instrumented with the contagion index. Column (2) is based on OLS regression. By and large, the predicted region-specific growth rates of real income are stable. The correlation of the country-specific results in the baseline with the instrumented and uninstrumented results are very high, with a correlation coefficient of 0.97 in both cases, statistically significant at the $1 \%$ level. With a single PTA dummy, the expected effects are slightly larger. But the overall tendencies are similar, except for ASEAN and China. For these two regions, the baseline predicts negative results of around $0.2 \%$, while the effects are positive and in the order of magnitude of $0.1 \%$ with a single PTA dummy.

The real income changes in column (4) are based on trade elasticity estimates including a shallow and deep PTA dummy, but the PTA dummies are not instrumented. The correlation coefficient of the country-specific results in the baseline with this specification is again very high, 0.98 and statistically highly significant. The sorting of the regions is very similar, with the largest negative effects in China and the ASEAN region. But the predicted effects are substantially smaller. TTIP is still predicted to be positive for TTIP countries, on average, but it only raises real income by $0.4 \%$.

Last, column (5) presents results when sectoral heterogeneity in the treatment intensity is supressed. We run two estimations on pooled sectoral data, one for the manu- 
Table A20: Sensitivity check: Results with alternative empirical specifications

\begin{tabular}{|c|c|c|c|c|c|}
\hline \multirow{4}{*}{ Estimation: } & (1) & (2) & $(3)$ & (4) & $(5)$ \\
\hline & \multicolumn{5}{|c|}{ Welfare growth (in \%) } \\
\hline & \multirow{2}{*}{$\begin{array}{c}\text { Base } \\
\text { IV }\end{array}$} & \multicolumn{2}{|c|}{ Single PTA dummy } & \multicolumn{2}{|c|}{ Shallow/Deep } \\
\hline & & IV & OLS & OLS & Pooled IV \\
\hline TTIP & 2.37 & 2.46 & 2.80 & 0.42 & 1.15 \\
\hline USA & 2.68 & 2.80 & 3.17 & 0.47 & 1.27 \\
\hline EU27 & 2.12 & 2.17 & 2.50 & 0.38 & 1.04 \\
\hline Non-TTIP & -0.03 & 0.06 & 0.08 & -0.03 & -0.13 \\
\hline Rest of World & 0.40 & 0.51 & 0.60 & 0.06 & 0.18 \\
\hline Rest of Europe & 0.29 & 0.40 & 0.48 & 0.03 & 0.07 \\
\hline Central Asia & 0.20 & 0.29 & 0.34 & 0.02 & 0.02 \\
\hline Eurasian Customs Union & 0.17 & 0.19 & 0.23 & 0.02 & 0.02 \\
\hline $\mathrm{SACU}^{a}$ & 0.15 & 0.20 & 0.24 & -0.00 & -0.05 \\
\hline $\mathrm{EFTA}^{b}$ & 0.15 & 0.26 & 0.31 & -0.02 & -0.13 \\
\hline Canada & 0.12 & 0.13 & 0.17 & -0.02 & -0.17 \\
\hline $\mathrm{MENA}^{c}$ & 0.12 & 0.20 & 0.24 & -0.00 & -0.03 \\
\hline Latin America \& Caribbean & 0.11 & 0.15 & 0.17 & 0.02 & 0.06 \\
\hline Sub-Saharan Africa & 0.10 & 0.19 & 0.22 & -0.00 & -0.03 \\
\hline Turkey & 0.10 & 0.12 & 0.15 & -0.00 & -0.01 \\
\hline Oil exporters & 0.09 & 0.26 & 0.30 & -0.04 & -0.19 \\
\hline Australia \& New Zealand & 0.08 & 0.12 & 0.14 & -0.00 & -0.02 \\
\hline Oceania & 0.06 & 0.14 & 0.16 & -0.01 & -0.04 \\
\hline South Asia & 0.06 & 0.13 & 0.15 & 0.00 & 0.01 \\
\hline MERCOSUR & 0.00 & 0.03 & 0.04 & -0.02 & -0.05 \\
\hline Pacific Alliance & -0.07 & -0.07 & -0.06 & -0.06 & -0.25 \\
\hline East Asia & -0.13 & -0.14 & -0.16 & -0.04 & -0.14 \\
\hline $\mathrm{ASEAN}^{d}$ & -0.19 & 0.06 & 0.07 & -0.07 & -0.29 \\
\hline China & -0.23 & 0.08 & 0.10 & -0.08 & -0.29 \\
\hline World & 1.32 & 1.40 & 1.60 & 0.22 & 0.58 \\
\hline
\end{tabular}

Note: The regional real income change is a GDP-weigthed sum of the respective countries' real income changes. An overview of the classification of countries into regions is provided in the online appendix. Base: deep TTIP scenario. Columns with IV based on instrumental variables regression. Columns with OLS based on ordinary least squares regression. Column (5) based on pooled sectoral estimation, i.e. all manufacturing sectors have the same estimated productivity dispersion and PTA treatment, the same is true for all service sectors.

${ }^{a}$ Southern African Customs Union, ${ }^{b}$ European Free Trade Association, ${ }^{c}$ Middle East \& North Africa, ${ }^{d}$ Association of Southeast Asian Nations.

facturing sector, one for the service industries. ${ }^{2}$. The average productivity dispersion is

\footnotetext{
${ }^{2}$ The regression results are given in Table A18 in the online appendix
} 
approximately $1 / 5.6$. This finding is in line with the literature, which typically finds estimates of the elasticity of substitution of between 5-7, (see e.g. Broda and Weinstein, 2006; Bergstrand et al., 2012). Shallow treaties have positive effects on bilateral trade, but the empirical evidence is less strong for service industries. Deep agreements, on the other hand, have a strong positive and statistically significant effect in both manufacturing and services. The estimates suggest, that a deep PTA increases bilateral manufacturing trade by 1.7 or $170 \%\left(\equiv e^{0.999}-1\right)$ and service trade by around $25 \%$. On the country level, the correlation of real income changes with the base scenario is again very high, 0.92 , and statistically significant. For TTIP countries, the effects are in the order of magnitude of $1 \%$ real income increase. So they are smaller than in the baseline. The negative effect on non-TTIP countries is more pronounced, with $-0.13 \%$ on average. China and the ASEAN region are again the biggest losers. 


\section{References}

Baldwin, Richard and Dany Jaimovich, "Are Free Trade Agreements contagious?," Journal of International Economics, 2012, 88 (1), 1 - 16.

Bergstrand, Jeffrey H., Peter Egger, and Mario Larch, "Gravity Redux: Estimation of gravity-equation coefficients, elasticities of substitution, and general equilibrium comparative statics under asymmetric bilateral trade costs," Journal of International Economics, 2012.

Broda, C. and D. Weinstein, "Globalization and the Gains from Variety," Quarterly Journal of Economics, May 2006, 121 (2), 541-585.

Dür, Andreas, Leonardo Baccini, and Manfred Elsig, "The Design of International Trade Agreements: Introducing a New Database," Review of International Organizations, 2014, $9(3), 353-375$.

Martin, Philippe, Thierry Mayer, and Mathias Thoenig, "The Geography of Conflicts and Regional Trade Agreements," American Economic Journal: Macroeconomics, October 2012, 4 (4), 1-35. 